UNIVERSIDADE DE SÃO PAULO

FACULDADE DE MEDICINA DE RIBEIRÃO PRETO

WILLIAM MARCIEL DE SOUZA

Estudo evolutivo dos hantavírus e desenvolvimento de uma RTPCR quantitativa em tempo real para detecção do vírus Araraquara

Ribeirão Preto, SP 
Estudo evolutivo dos hantavírus e desenvolvimento de uma RTPCR quantitativa em tempo real para detecção do vírus Araraquara

Dissertação apresentada à Faculdade de Medicina de Ribeirão Preto da Universidade de São Paulo, para obtenção do Título de Mestre em Ciências, pelo programa de Imunologia Básica e Aplicada, opção: Bioagentes Patogênicos.

Orientador: Prof. Dr. Luiz Tadeu Moraes Figueiredo

Ribeirão Preto, SP 
AUTORIZO A REPRODUÇÃO E DIVULGAÇÃO TOTAL OU PARCIAL DESTE

TRABALHO, POR QUALQUER MEIO CONVENCIONAL OU ELETRÔNICO, PARA

FINS DE ESTUDO DE PESQUISA, DESDE QUE CITADA A FONTE.

Catalogação na Publicação

Serviço de Documentação

Faculdade de Medicina de Ribeirão Preto da Universidade de São Paulo

Souza, William Marciel de

Estudo evolutivo dos hantavírus e desenvolvimento de uma RT-PCR quantitativa em tempo real para detecção do vírus Araraquara / William Marciel de Souza; orientador: Prof. Dr. Luiz Tadeu Moraes Figueiredo - Ribeirão Preto, 2013.

101 p. : il. ; $30 \mathrm{~cm}$

Dissertação - Faculdade de Medicina de Ribeirão Preto - Departamento de Bioquímica e Imunologia - Universidade de São Paulo, 2013.

1. Hantavírus -2 . RT-PCR em tempo real -3 . Evolução -4 . Filogeografia 


\title{
Estudo evolutivo dos Hantavírus e desenvolvimento de uma RT-PCR quantitativa em tempo real para detecção do vírus Araraquara
}

\author{
Dissertação apresentada à Faculdade de Medicina \\ de Ribeirão Preto da Universidade de São Paulo, \\ para obtenção do Título de Mestre em Ciências, \\ pelo programa de Imunologia Básica e Aplicada, \\ opção: Bioagentes Patogênicos.
}

Apresentada em 28 de Março de 2013;

BANCA EXAMINADORA

Prof. Dr. Luiz Tadeu Moraes Figueiredo

Faculdade de Medicina de Ribeirão Preto da Universidade de São Paulo

Prof. Dr. Victor Hugo Aquino Quintana

Faculdade de Ciências Farmacêuticas de Ribeirão Preto da Universidade de São Paulo

Prof. Dr. Edison Luiz Durigon

Instituto de Ciências Biomédicas da Universidade de São Paulo. 


\section{DEDICATÓRIA}

Dedico este trabalho a minha namorada Cíntia pelo amor, companheirismo e paciência. Ao meu pai (in memoriam), e meu "irmão" Eduardo. 


\section{AGRADECIMENTOS}

A meu orientador Prof. Dr. Luiz Tadeu Moraes Figueiredo pela oportunidade, transmissão de conhecimentos, simplicidade e paciência.

Ao Prof. Dr. Edison Luiz Durigon pela avaliação e contribuição neste trabalho.

Ao Prof. Dr. Victor Hugo Aquino Quintana pela avaliação e por ter gentilmente disponibilizado a utilização de seu laboratório.

Aos colaboradores diretos, Prof. Dr. Gonzalo José Bello Bentancor nas análises filogeográficas, e ao Dr. Alex Martins Machado pela contribuição no desenvolvimento da RTPCR em tempo real.

Ao Alberto Anastásio Amarilla Ortiz e Helda Liz Alfonso pelas orientações nas análises filogenéticas.

A Fundação de Apoio à Pesquisa do Estado de São Paulo pela bolsa e o financiamento para realização deste estudo.

A todos os colegas de laboratório e aos demais professores, alunos e funcionários do Centro de Pesquisa em Virologia que de maneira direta ou indireta auxiliaram no planejamento e execução deste trabalho.

Aos professores do Programa de Imunologia Básica Aplicada. A Ana Cristina, secretária do Programa de Imunologia Básica Aplicada, pelo modo solícito com que atendeu a todas as minhas dúvidas durante estr período.

A todos os meus colegas do programa pelos momentos de estudos e diversão.

Aos meus amigos pelo incentivo em todos os momentos.

A todos os colaboradores anônimos, presentes e ausentes, que de alguma forma nós auxiliaram na execução deste projeto. 
SOUZA, W.M. Estudo evolutivo dos Hantavírus e desenvolvimento de uma RT-PCR quantitativa em tempo real para detecção do vírus Araraquara. 2013-101f. Dissertação (Mestrado) Faculdade de Medicina de Ribeirão Preto, Universidade de São Paulo, Ribeirão Preto.

\section{RESUMO}

O gênero Hantavírus está incluído na família Bunyaviridae que são vírus emergentes associados a roedores que podem infectar o homem causando graves doenças. Nas Américas, os Hantavírus causam uma síndrome pulmonar e cardiovascular (SPCVH) com alta letalidade. Cerca de 1600 casos de SPCVH já foram notificados no Brasil causando mais de 600 óbitos. Sete espécies de Hantavírus são conhecidas no Brasil incluindo o vírus Araraquara que circula nas regiões de cerrado do país associado ao roedor Necromys lasiurus. Para o desenvolvimento de uma RT-PCR em tempo real para detecção e quantificação de Hantavírus, mostramos as etapas para o desenvolvimento de uma one-step RT-PCR em tempo real SYBR Green I para Hantavírus Araraquara que se mostrou específica para o gênero e capaz de detectar até 10 cópias por mL de RNA viral na amostra. Além disso, realizamos um estudo filogenético utilizando algoritmos bayesianos, com 190 sequências completas do gene da nucleoproteína, oriundas de 30 países durante um período de 25 anos (1985-2010) que encontravam-se disponíveis no GenBank (NCBI). Baseando-se em uma taxa média de 6.8 x $10^{-4}\left(2.5 \times 10^{-4}-1 \times 10^{-3}\right)$ substituições nucleotídicas por sítio/ano, foi possível inferir que os Hantavírus teriam aproximadamente 1917 anos. O processo de dispersão dos Hantavírus pelo mundo teria ocorrido há aproximadamente 500 anos, e a introdução destes vírus nas Américas teria ocorrido há 549 anos (95\% HPD 1555-341 anos), via América Central ou México, originando os Hantavírus adaptados aos roedores da subfamilia Neotominae, e pelo Brasil surgindo há 406 anos (95\% HPD 1150-250 anos) os Hantavírus associados a roedores da subfamília Sigmodontinae, e posteriormente dispersaram para todo o continente sulamericano. O trabalho contribui de forma relevante para o diagnóstico das infecções por Hantavírus com a one-step RT-PCR em tempo real SYBR Green I e também, contribui para o entendimento da filogenia e história destes vírus, oferecendo subsídios ao entendimento sobre como teria ocorrido o espalhamento dos Hantavírus pelo mundo.

Palavras-chaves: Hantavírus, RT-PCR em tempo real, Evolução e Filogeografia. 
SOUZA, W.M. Evolutionary study of Hantavirus and development of a quantitative real time RT-PCR for detection of Araraquara virus. 2013-101f. Dissertação (Mestrado) Faculdade de Medicina de Ribeirão Preto, Universidade de São Paulo, Ribeirão Preto.

\begin{abstract}
The genus Hantavirus is included in the family Bunyaviridae are viruses emerging carried by rodents, which can infect humans causing serious illness. In the Americas, the Hantavirus causing a pulmonary syndrome (HPS) with high lethality. About 1,600 cases of HPS have been reported in Brazil, cause over 1600 deaths. Seven species of Hantavirus are known in Brazil, including Araraquara virus circulating in Cerrado regions (or Savannah regions) of the related in rodents Necromys lasiurus. The development of a real-time RT-PCR for detection and quantitation of Araraquara virus, here we show the steps for developing a one-step SYBR Green real-time RT-PCR for virus Araraquara which proved to be specific for the genus and capable of detecting up to 10 copies of viral RNA per $\mathrm{ml}$ in the sample. Furthemore, we performed a phylogenetic analysis using Bayesian algorithms, with 190 complete sequences of the nucleoprotein gene, originating from 30 countries over a 25 year period (1985-2010) that were available in GenBank (NCBI). Based on an average rate of $6.8 \times 10^{-4}\left(2.5 \times 10^{-4}-1\right.$ $\mathrm{x} 10^{-3}$ ) nucleotide substitutions per site/year, it was possible to infer that the Hantavirus would be about 1917 years old. The Hantavirus spreading in the world have occurred for nearly 500 years, and the introduction of these viruses have occurred in the Americas 549 years ago (95 years\% HPD 1555-341) bye Central America or Mexico, causing the Hantavirus adapted to rodents subfamily Neotominae, and Brazil emerged 406 years ago (95\% HPD 1150-250 years) the Hantavirus associated with rodents subfamily Sigmodontinae, and subsequently disseminated to South America. The work contributes significantly to the diagnosis of Hantavirus infections with one-step SYBR Green real-time RT-PCR and also contributes to an understanding of the phylogeny and evolutionary history of these viruses, offering subsidies have occurred understanding of how the Hantavirus spread of the world wide.
\end{abstract}

Keywords: Hantavirus, real time RT-PCR, Evolution and Phylogeographic. 


\section{LISTA DE FIGURAS}

Figura 1. Distribuição dos principais Hantavírus nas Américas e os seus roedoresreservatórios.

Figura 2. Casos e óbitos notificados de Hantavírus e roedor-reservatórios do Brasil. 15

Figura 3. Esquema de um virion Hantavirus.

Figura 4. Replicação dos Hantavírus.

Figura 5. O pulmão na SPCVH

Figura 6. Diferença entre respostas imunes à infecção por Hantavírus em roedoresreservatório e em seres humanos

Figura 7. Cinética da infecção por Hantavírus em roedores

Figura 8. Transmissão dos Hantavírus entre roedores e envolvendo outros animais incluindo o homem

Figura 9: Curva padrão da one-step RT-PCR em tempo real para vírus Araraquara

Figura 10. Temperatura de melting da one-step RT-PCR em tempo real para vírus Araraquara

Figura 11. Árvore filogenética usando o método de Maximum Likelihood do segmento S dos Hantavírus

Figura 12. Frequência da divergência nucleotídicas e aminoacídicos entre Hantavírus associados a subfamílias de roedores reservatórios

Figura 13. Árvore de 190 sequências do segmento S de Hantavírus associados a roedores

Figura 14: Dispersão dos Hantavírus pela linha do tempo utilizando o uma reconstrução Bayesian skyline.....

Figura 15: Probabilidades geográficas da origem de ancestrais comuns dos Hantavírus 49

Figura 16: Prováveis rotas de dispersão dos Hantavírus associados a roedores pelo mundo 


\section{LISTA DE TABELAS}

Tabela 1. Resumo dos Parâmetros que tiveram variações experimentadas visando otimizar a one-step RT-PCR em tempo real...

Tabela 2. Comparação da RT-PCR convencional com a RT-PCR em tempo real na detecção do Hantavírus Araraquara em materiais clínicos de origem humana e de roedores

Tabela 3. Países, número e ano das sequências nucleotídicas do segmento $\mathrm{S}$ dos Hantavírus associados a roedores

Tabela 4. Estimativa média de divergência evolutiva entre os grupos de Hantavírus com base em nucleotídeos e aminoácidos do segmento $\mathrm{S}$

Tabela 5. Países, número e ano das sequências nucleotídicas do segmento $\mathrm{S}$ dos Hantavírus associados a roedores, utilizadas para a análise filogeográfica 


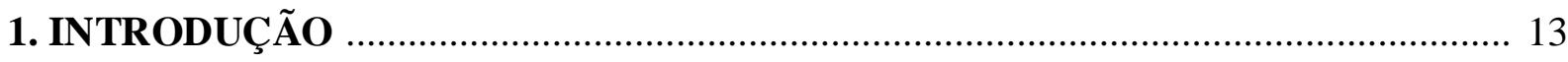

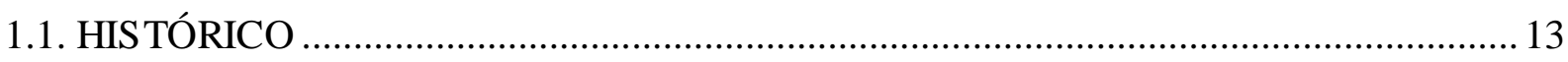

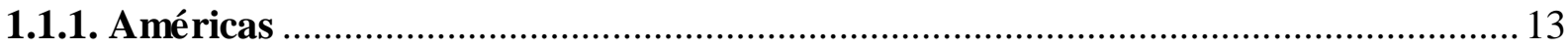

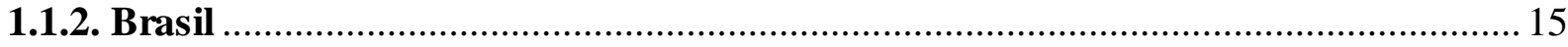

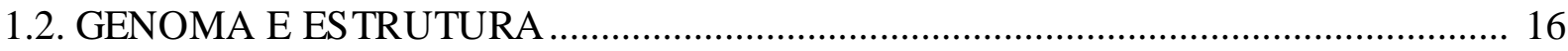

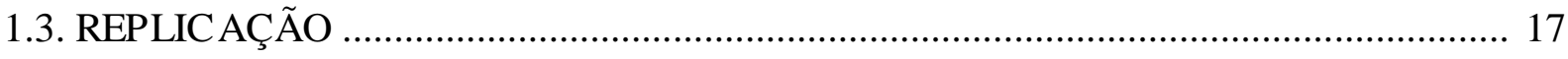

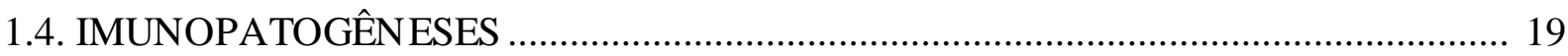

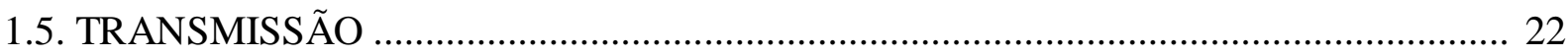

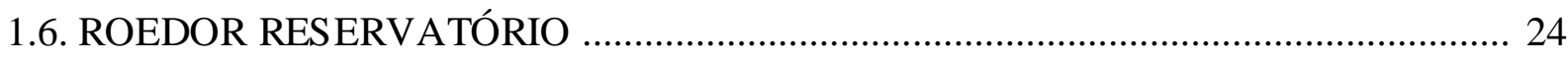

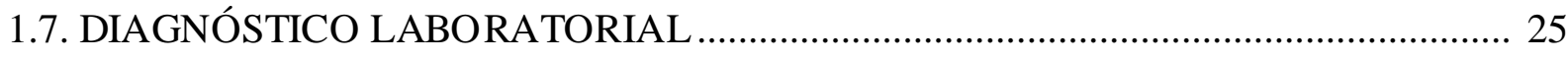

1.8. JUSTIFICATIVA …………………………………………………………. 26

2. OBJETIVO

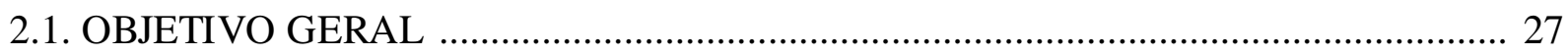

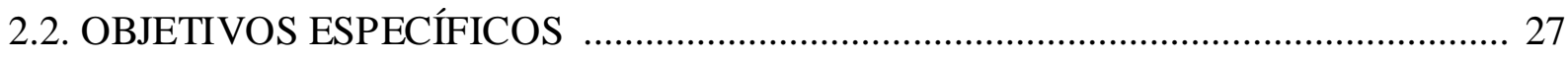

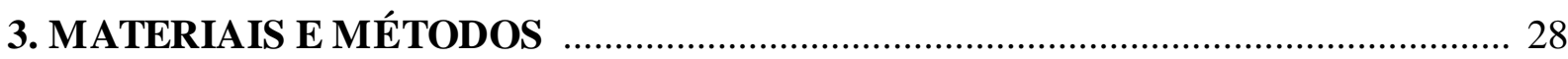

3.1. DESENVOLVIMENTO DE UMA RT-PCR EM TEMPO REAL …………………..... 28

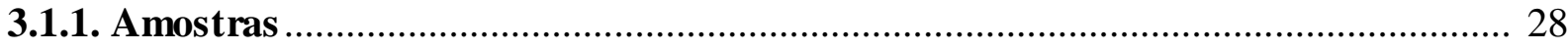

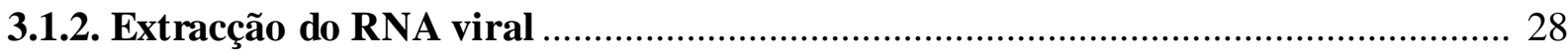

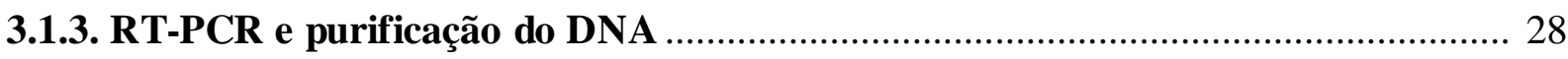

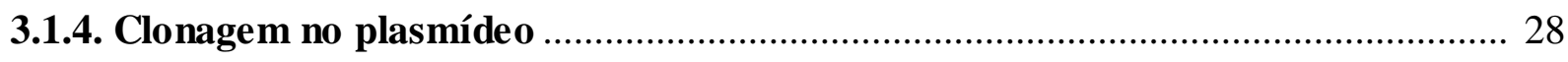

3.1.5. Transformação de células competentes .................................................................. 28

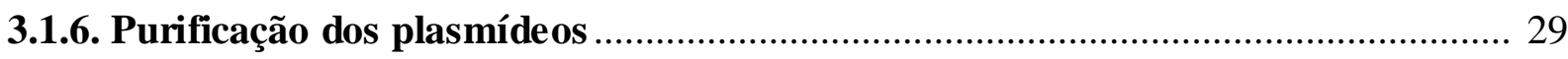

3.1.7. Transcrição in vitro .......................................................................................... 30

3.1.8. Padronização de uma one-step RT- PCR em tempo real ........................................ 30

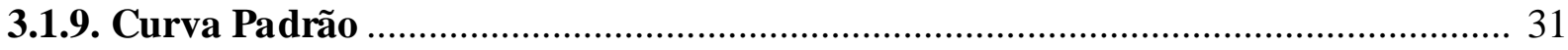

3.1.10. Limite de Deteç̧ão........................................................................................ 31

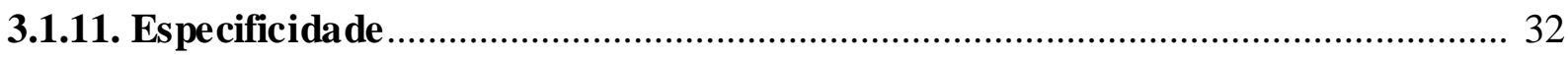

3.1.12. Validação da RT- PCR em tempo real ……………........................................ 32

3.2. ESTUDO EVOLUTIVO DOS HANTAVÍRUS ASSOCIADOS A ROEDORES .......... 32

3.2.1. Base de dados com sequências de Hantavírus.......................................................... 32

3.2.2. Análise filogenética dos Hantavírus associados a roedores .................................... 32 
3.2.3. Análise da divergência evolutiva

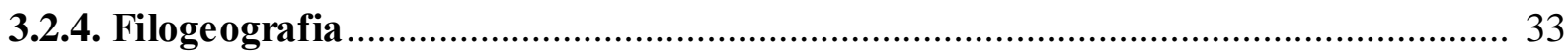

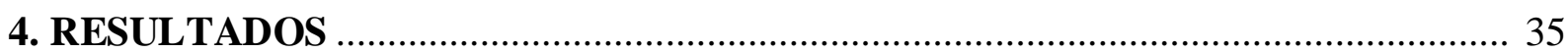

4.1. DESENVOLVIMENTO DE UMA RT-PCR EM TEMPO REAL …............................ 35

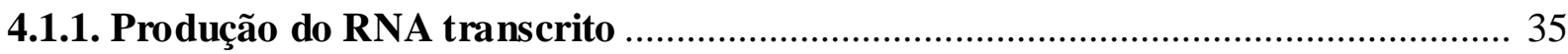

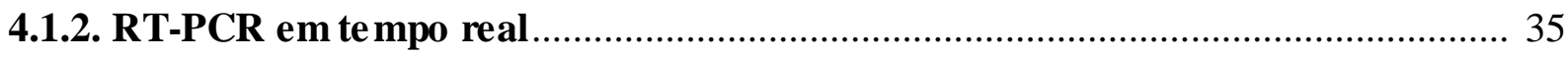

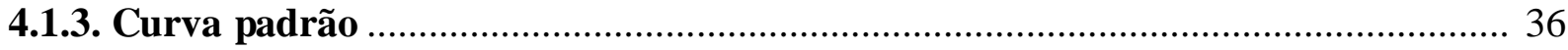

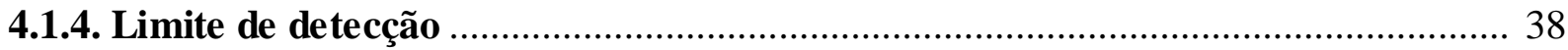

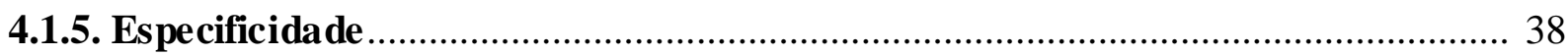

4.1.6. Validação da RT- PCR em tempo real ............................................................. 39

4.2. ESTUDO EVOLUTIVO DOS HANTAVÍRUS ASSOCIADOS A ROEDORES .......... 40

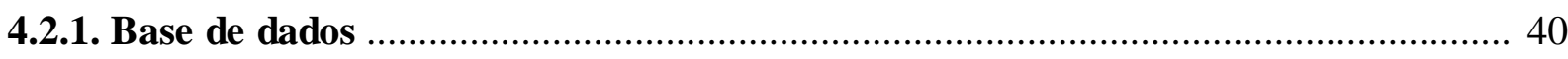

4.2.2. Análise filogenética dos Hantavírus associados a roedores ................................ 41

4.2.3. Divergência filogenética entre Hantavírus associados às subfamílias de roedores

4.2.4. Análise dos Hantavírus associado às subfamílias de roedores .............................. 42

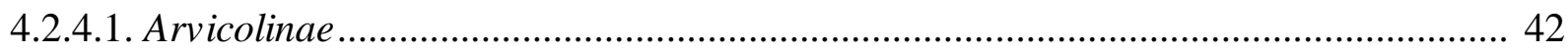

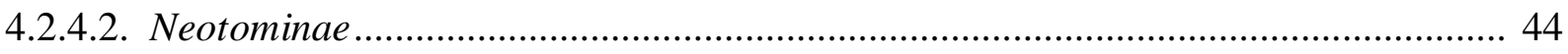

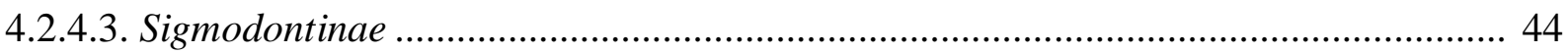

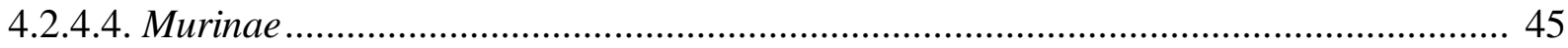

4.2.5. Análise filogeográfica dos Hantavírus associados a roedores............................... 46

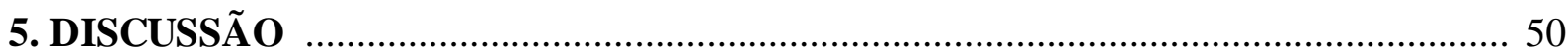

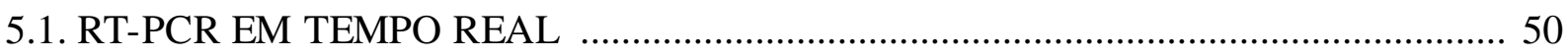

5.2. ESTUDO EVOLUTIVO DOS HANTAVÍRUS ASSOCIADOS A ROEDORES .......... 53

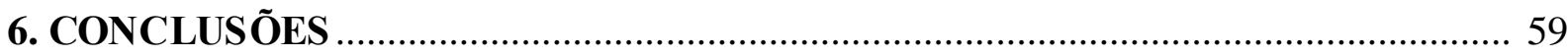

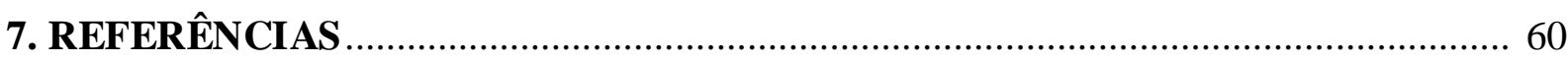

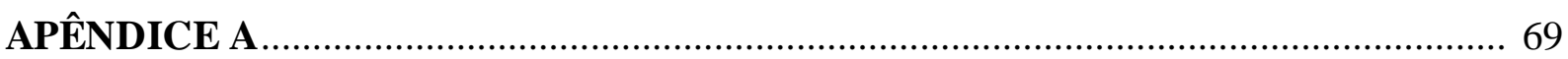

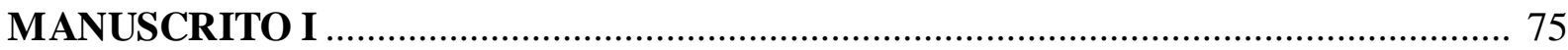

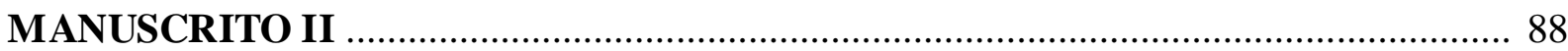




\section{INTRODUÇÃO}

\subsection{HISTÓRICO}

Os registros mais antigos que descrevem uma doença com sintomas que poderiam corresponder à infecção por Hantavírus, datam de aproximadamente mil anos. Entretanto, estudos sobre evolução dos Hantavírus hipotetizam que estes teriam se originado há aproximadamente 900 anos (RAMSDEN et al, 2008; RAMSDEN, HOLMES, CHARLESTON, 2009). Relatos, mais recentes, durante a Primeira (1914-1918) e Segunda Guerras Mundiais (1939-1945), alegam que ocorria uma doença com sintomatologia sugestiva de infecção por Hantavírus, conhecida como "nefrite de trincheira" (MIR, 2010).

Apesar de descrita clinicamente, o agente etiológico da "nefrite de trincheira", posteriormente denominada como Febre Hemorrágica Coreana, durante a Guerra das Coréias (1950-1953) só foi conhecido vinte e três anos após o fim desta guerra. Tudo começou com a identificação do vírus Hantaan, protótipo do gênero Hantavírus, em roedores silvestres da espécie Apodemus agrarius, capturados próximos ao rio Han na Coréia do Sul (LEE, LEE, JOHNSON, 1978). No entanto, logo descobriu-se que os Hantavírus não estavam restritos somente a está região. Uma doença que ocorria em diversos países da Ásia e Europa, conhecida como Nefropatia Epidêmica, foi relacionada com Hantavírus. Diversos Hantavírus foram identificados como sendo responsáveis por esta doença, e denominados de acordo com o nome do local onde foram encontrados, tais como Seoul, Dobrava e Puumala, entre outros (VAPALAHTI et al., 2003).

Atualmente, milhares de pessoas são acometidas a cada ano por Hantavírus na Ásia e Europa, e a doença que apresentam denomina-se Febre Hemorrágica com Síndrome Renal (FHSR), com letalidade de 1 a 8\% (JONSSON, FIGUEIREDO, VAPALAHTI, 2010).

\subsubsection{Américas}

Nas Américas, o primeiro indício da presença destes vírus ocorreu em 1984 nos Estados Unidos da América (EUA), quando isolou-se o Hantavírus Prospect Hill em roedores silvestres da espécie Microtus pennsyvanicus (YANAGIHARA et al., 1987). Todavia, estes vírus tornaram-se importantes apenas quando descobriu-se que os mesmos causavam doença humanas grave. Isto ocorreu após um surto na região de Four Corners (Novo México, Arizona, Colorado e Utah), em maio de 1993, nos EUA. Diferentemente dos casos ocorridos na Ásia e Europa, em que os indivíduos eram acometidos com uma FHSR, este vírus ocasionava uma doença respiratória aguda de alta letalidade entre os índios navajos, sendo 
descrita como Síndrome Pulmonar por Hantavírus (SPH) ou Síndrome Pulmonar e Cardiovascular por Hantavírus (SPCVH), ocasionada pelo vírus Sin Nombre, que foi posteriormente isolado do tecido de roedores silvestres da espécie Peromyscus maniculatus (NICHOL et al., 1993).

Após o reconhecimento dos vírus Prospect Hill e Sin Nombre, identificaram-se muitos outros Hantavírus em vários países no continente americano, sendo que atualmente o número de espécies virais estimado é superior a 40, sendo 21 associados à SPCVH. Estes vírus têm como reservatórios roedores da subfamilia Neotominae e Sigmodontinae, conforme apresentado na Figura 1 (HJELLE, TORREZ, 2011).

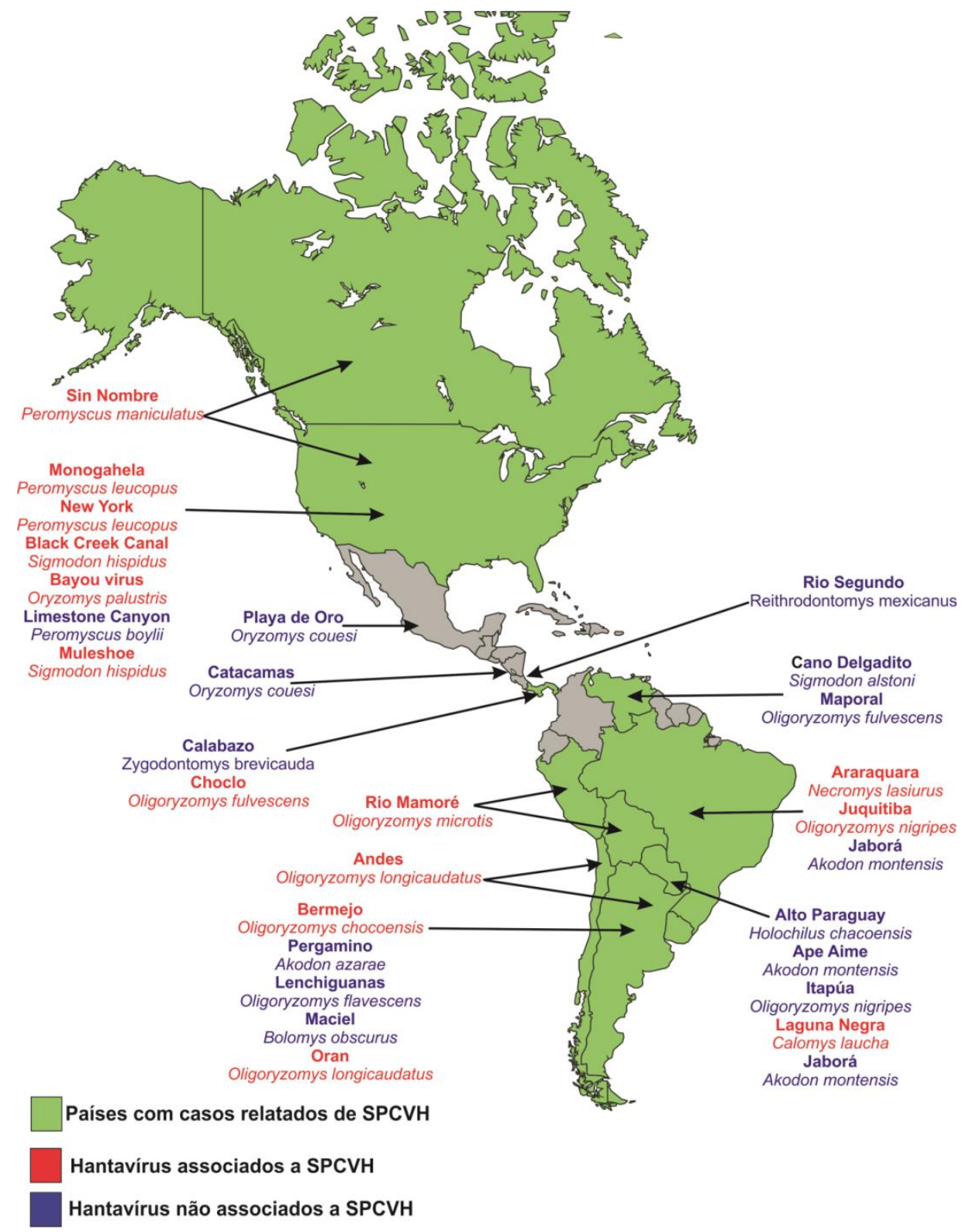

Figura 1. Distribuição dos principais Hantavírus nas Américas e os seus roedoresreservatórios. Adaptado: HJELLE, TORREZ, 2011. 


\subsubsection{Brasil}

No Brasil, o interesse pelos Hantavírus teve início na década de 1980, com a realização de inquéritos sorológicos em populações humanas e de roedores, utilizando técnicas imunoenzimáticas para vírus Hantaan e Seoul (LEDUC et al., 1985; VASCONCELOS et al., 1992; HINDRICHSEN et al., 1993; IVERSSON et al., 1994). Contudo, o primeiro registro desta doença no Brasil ocorreu apenas em 1993, quando três indivíduos na área rural do município de Juquitiba, estado de São Paub, tiveram graves quadros causados pelo Hantavírus Juquitiba (JOHNSON et al., 1999). Desde então, com a ocorrência de mais de 1500 casos de doença humana, o estudo sobre Hantavírus no Brasil foi intensificado, sendo realizados diversos estudos epidemiológicos e moleculares que confirmaram a circulação destes vírus em todas as regiões do Brasil, como mostrado na Figura 2 (FIGUEIREDO et al., 2009A; MINISTÉRIO DA SAÚDE, 2012). Sete espécies de Hantavírus foram descritas no país, duas não relacionadas à doença humana até o momento, são os vírus Rio Mearim e Jaborá, respectivamente encontrados na região Norte e Sul do Brasil (JONSSON, FIGUEIREDO, VAPALAHTI, 2010).

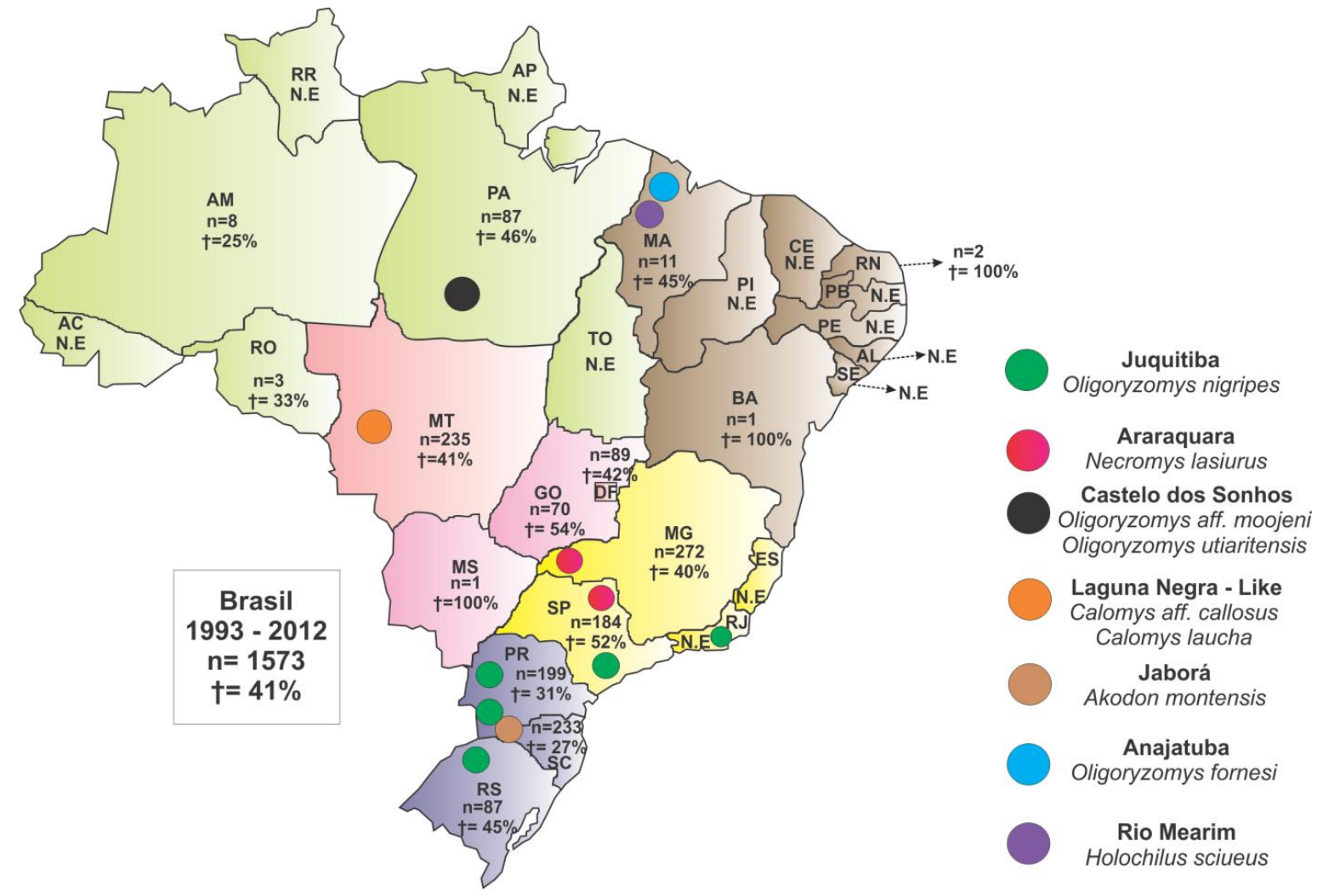

Figura 2. Casos e óbitos de SPCVH e roedores-reservatório de Hantavírus no Brasil. Dados atualizados até 25 de maio de 2012 pelo Ministério da Saúde, disponível em www. portal.saude.gov.br. 
As seguintes espécies de Hantavírus são associadas à SPCVH no Brasil: vírus Juquitiba (tem como variante o vírus Araucária), vírus Araraquara (tem como variante o vírus Paranoá), vírus Laguna Negra-like, vírus Castelo dos Sonhos e vírus Anajatuba, mostrado na Figura 2 (JONSSON, FIGUEIREDO, VAPALAHTI, 2010).

Pela grande importância em saúde pública, a SPCVH é reconhecida pelo Ministério da Saúde como um agravo de notificação compulsória, tendo sido notificados, desde 1993 até o presente, mais de 1.500 casos, com uma letalidade de aproximadamente $40 \%$, variando de acordo com regiões geográficas e vírus circulantes, como apresentado na Figura 2. Diferente da média nacional, o Hantavírus Araraquara que ocorre no noroeste do estado de São Paulo e no estado de Minas Gerais, produz SPCVH com a mais alta letalidade do Brasil e provavelmente, do mundo, superior a 50\%, como mostrado na Figura 2 (MINISTÉRIO DA SAÚDE, 2012).

\subsection{GENOMA E ESTRUTURA}

Os membros da familia Bunyaviridae são vírus RNA de polaridade negativa com três segmentos circulares (WALTER, BARR, 2011). Essa família é muito diversificada e possui mais de 350 espécies de vírus, divididas em cinco gêneros: Orthobunyavírus, Nairovírus, Phlebovírus, Hantavírus e Tospovírus (GUU, ZHENG, TAO, 2012). São majoritariamente causadores de infecção animal com exceção dos Tospovírus, que infectam vegetais. Orthobunyavírus, Nairovírus e Phlebovírus têm como vetores artrópodes e os Hantavírus são vírus associados pincipalmente a roedores (ELLIOT, 2009; GUU, ZHENG, TAO, 2012).

O genoma dos Hantavírus possui de 12.000 a 13.000 nucleotídeos divididos em três segmentos, como mostrado na Figura 3. O segmento L (large), com $\sim 6,5 \mathrm{~kb}$ (kilobase) é responsável por codificar a enzima polimerase e está relacionado com funções de transcriptase / replicase viral. $\mathrm{O}$ segmento $\mathrm{M}$ (medium), com $\sim 3,6 \mathrm{~kb}$, possui regiões com maior variabilidade entre os Hantavírus sendo o codificador das glicoproteínas Gn e Gc da superfície viral, responsáveis pela entrada do vírus na célula-alvo (JONSSON, FIGUEIREDO, VAPALAHTI, 2010).

O segmento $\mathrm{S}$ (small), com $\sim 1,7 \mathrm{~Kb}$, codifica a proteína do nucleocapsídio que envolve o RNA viral (WALTER, BARR, 2011; GUU, ZHENG, TAO, 2012), como mostrado na Figura 2. Entretanto, estudos recentes sugerem que o segmento $S$ de alguns Hantavírus como os vírus Tula e Andes, possua estrutura de leitura aberta (open reading frame, ORF) que codificaria uma proteína não estrutural inibidora de IFN do tipo I (VERA-OTAROLA et al., 2012; VIRTANEN et al., 2010; JÄÄSKELÄINEN et al., 2008). 


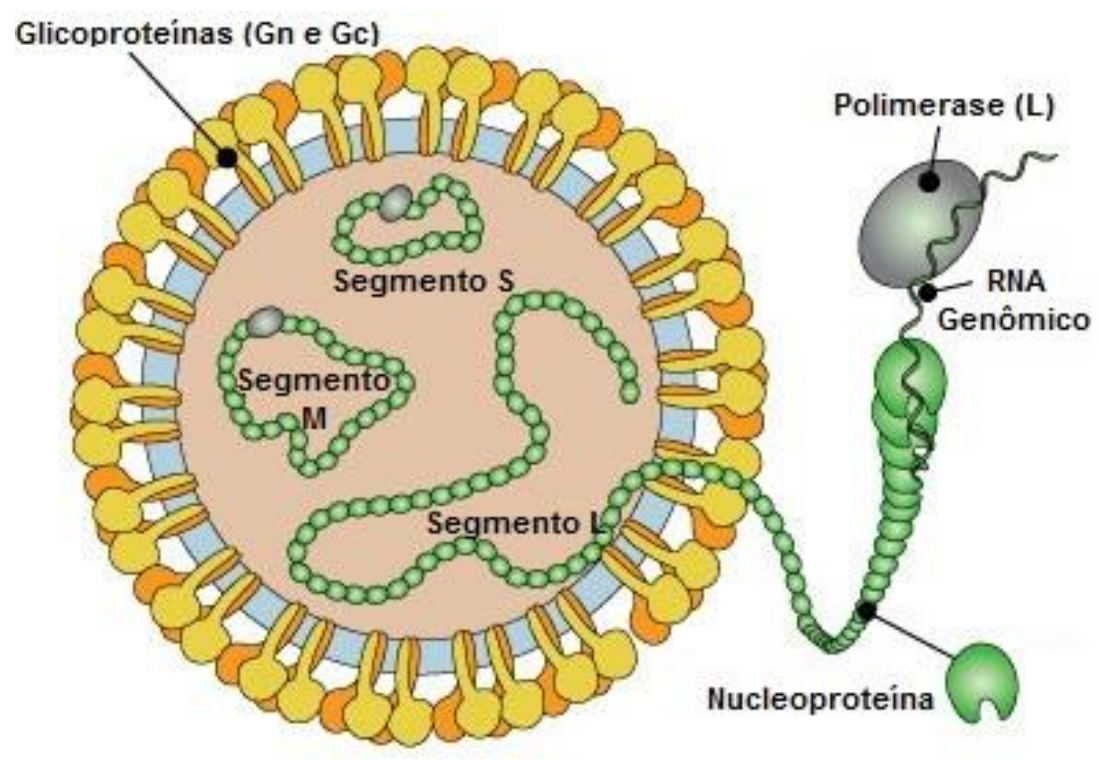

Figura 3. Esquema de um virion Hantavirus. O diâmetro do virion é de 80-120 nm e contêm os três segmentos genômicos de RNA circulares. Fonte: www.viralzone.expasy.org

\section{REPLICAÇÃO}

Os Hantavírus podem infectar diversas linhagens celulares, como células dendríticas, endoteliais, epiteliais, foliculares, linfócitos e macrófagos. A infecção destas células tem início quando as glicoproteínas virais ligam-se aos receptores de superfície celular da célula alvo (JONSSON, FIGUEIREDO, VAPALAHTI, 2010). Os principais receptores conhecidos para Hantavírus são as $\beta 3$ integrinas, relacionadas aos Hantavírus patogênicos para o homem e as $\beta 1$ integrinas, relacionadas aos não patogênicos (GRAVILOVSKAYA et al., 1998). Recentemente, observou-se que a glicoproteína viral $(\mathrm{Gn})$ interagiria com co-receptores CD55 e DAF (fator acelerador da dissociação, responsável por acelerar o efeito da C3 do sistema complemento) no momento de adsorção viral (MACKOW, GAVRILOVSKAYA, 2009).

Após as glicoproteínas virais ligarem-se aos receptores da célula alvo, o Hantavírus penetram no citoplasma por endocitose em vesículas da proteína clatrina. Em seguida, o envelope viral funde-se à membrana endossômica o que permite às três ribonucleoproteínas virais cairem no citoplasma. Nessas ribonucleoproteínas, a RdRp (RNA polimerase dependente de RNA) inicia a transcrição primária originando mRNAs (RNAs mensageiros), como apresentado na Figura 4 (MIR, 2010; HJELLE, TORREZ, 2011).

A transcrição do RNA viral produz mRNA ou cRNA (RNA complementar), o molde de polaridade positiva utilizado na replicação do genoma que originará a progênie viral (SCHÖNRICH et al, 2008). Em seguida, nos ribossomos livres do citoplasma, inicia-se rapidamente a tradução dos mRNAs dos segmentos $\mathrm{L}$ e $\mathrm{S}$, enquanto que o mRNA do 
segmento M será traduzidos nos ribossomos do retículo endoplasmático (JONSSON, FIGUEIREDO, VAPALAHTI, 2010). Na sequência, os RNAs da progênie viral serão encapsidados, como apresentado na Figura 4.

A montagem e o egresso dos virions ocorrem após acúmulo de glicoproteínas Gc e Gn no complexo de Golgi. Os Hantavírus asiáticos e europeus saem da célula por brotamento nas vesículas do complexo de Golgi que são posteriormente excretados. Quanto aos Hantavírus americanos, Gn e Gc ancorariam na membrana plasmática e neste local, mediadas por microfilamentos de actina, ocorreriam à montagem e o brotamento dos virions para o exterior, conforme mostrado na Figura 4 (JONSSON, FIGUEIREDO, VAPALAHTI, 2010).

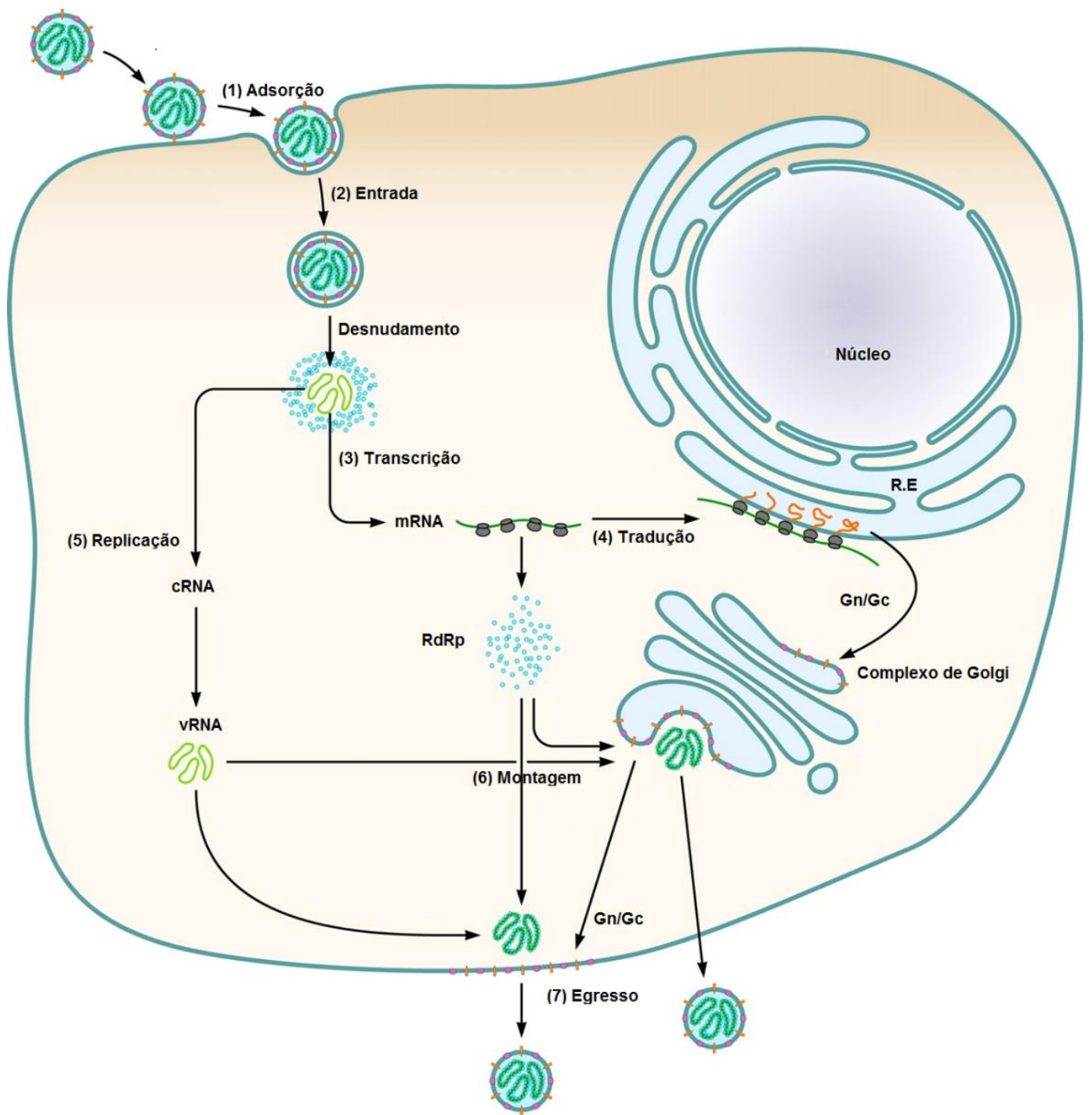

Figura 4. Replicação dos Hantavírus. 1. Ligação viral a receptores de superfície celular ( $\beta 1$ integrina ou $\beta_{3}$ integrina); 2. Entrada por endocitose após interação das glicoproteínas virais com o receptor seguido por fusão de envelope e liberação dos ribonucleocapsídios e da RdRp no citoplasma; 3. Transcrição primária; 4. Tradução das proteínas virais; 5. Replicação do RNA viral via cRNA intermediário; 6. Montagem de virions no aparelho de Golgi ou na 
membrana plasmática; 7. Saída por brotamento na membrana plasmática ou em vesícula do Golgi posteriormente excretada. Fonte: JONSSON, FIGUEIREDO, VAPALAHTI, 2010.

A infecção celular por Hantavírus induz grande produção da nucleoproteína viral $(\mathrm{N})$ no citoplasma e esta atua como uma chaperona de RNA, pois facilita a interação do RNA viral, constantemente desenvolvido e enovelado, com a RdRp. Também, N controlaria a transcrição primária de mRNA mudando-a para a do cRNA e permitindo a replicação do genoma viral (JONSSON, FIGUEIREDO, VAPALAHTI, 2010). Deste modo, a N induz resposta imune com produção de anticorpos nos animais e seres humanos infectados por Hantavírus e por isso é amplamente utilizada como antígeno em ensaios imunoenzimáticos que visam ao diagnóstico destas infecções (FIGUEIREDO et al., 2008; FIGUEIREDO et al., 2009B).

\subsection{IMUNOPATOGÊNESE}

Apesar dos diferentes órgãos mais acometidos na SPCVH e na FHSR, as duas síndromes possuem semelhanças. A infecção por Hantavírus, em ambos os casos, ocorre após inalação de partículas virais nas excretas de roedores infectados. Ambas as síndromes ocorrem após período de incubação de 2 a 4 semanas. Entretanto, o curso das doenças diverge de acordo com o órgão alvo, ou seja, a FHSR acomete principalmente os rins, e na SPCVH, o pulmão além do coração e vasos, são os principais órgãos afetados, como mostrado na Figura 5 (FIGUEIREDO, 2006; JONSSON, FIGUEIREDO, VAPALAHTI, 2010).

O sistema imune combate as infecções por Hantavírus de modo similar na SPCVH e na FHSR. A primeira linha de defesa é a imunidade inata com elevação de IRF-3, IRF-7, MxA, MHC I e II, CD11b, CD40, CD80, CD86 e células natural killer (NK). No entanto, IFN- $\alpha$, IFN- $\beta$, TLR3, RIG-I podem se comportar de forma distinta dependendo do Hantavírus infectante. Por outro lado, a supressão de INF's em alguns casos pode ser explicada pela ação da proteína não estrutural inibidora do vírus (EASTERBROOK; KLEIN, 2008; VERAOTAROLA et al., 2012; VIRTANEN et al., 2010).

A resposta imune celular é constituída principalmente por células $T C D 8+T_{H} 1$ que induzem uma intensa resposta de citocinas pró-inflamatórias, descrita como "tormenta de citocinas" (cytokine storm) (EASTERBROOK; KLEIN, 2008). Uma resposta inflamatória tão exacerbada induz edema pulmonar que chega à inundação do órgão levando à insuficiência respiratória, conforme apresentado na Figura 5. Também, concomitante, ocorre hipotensão resultante de uma redução do inotropismo que pode chegar ao choque cardiogênico. As 
principais citocinas responsáveis pelos quadros pulmonares e cardíacos são IFN- $\gamma$, TGF- $\beta$, IL4, IL-10, como mostrado na Figura 6B e C (BORGES et al., 2006; SCHÖNRICH et al., 2008, BORGES et al., 2010).

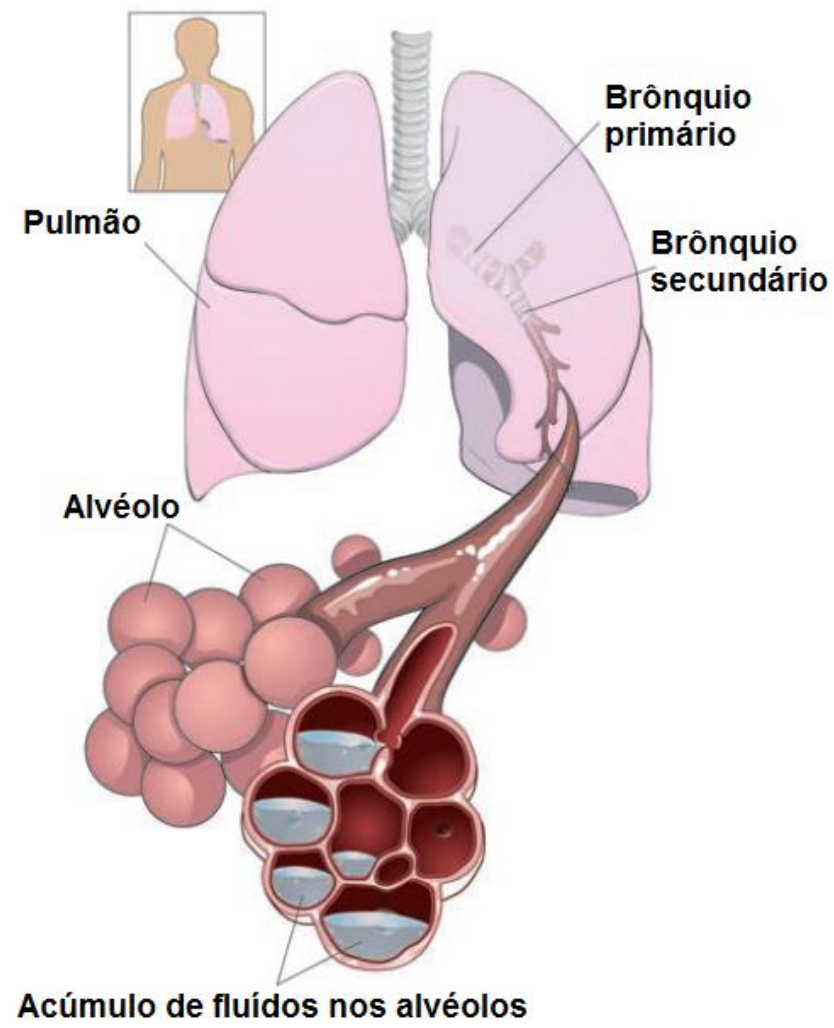

Figura 5. O pulmão na SPCVH: na SPCVH avançada os capilares abertos do leito vascular pulmonar permitem que os alvéolos inundem com o fluído plasmático impedindo troca de gases. Este evento resulta em dispnéia que pode levar o paciente ao óbito. Fonte: LEUENROTH, 2006.

Os megacariócitos originadores de plaquetas expressam altos níveis de $\beta 3$ integrina, e também são alvo do Hantavírus. Resulta desta infecção a trombocitopenia e a redução da adesividade plaquetária, explicando fenômenos hemorrágicos que ocorrem em muitos pacientes, como mostra a Figura 6C (MACKOW, GAVRILOVSKAYA, 2009).

A resposta humoral objetivando neutralizar e opsonizar as partículas virais, ocorre de forma intensa e por isso, observam-se elevados níveis de $\operatorname{IgM}, \operatorname{IgG}$, IgA e $\operatorname{IgE}$ específicos nas infecções por Hantavírus. Alguns estudos sugerem que os casos fatais de SPCVH estão associados a baixos níveis de anticorpos neutralizantes contra o vírus (BORGES et al., 2006; SCHÖNRICH et al., 2008). Do mesmo modo, sabe-se que pacientes com alelos HLA-B, haplótipos MHC: B35 e DR14 estão associados a quadros de SPCVH com maior letalidade (BORGES et al., 2006; EASTERBROOK; KLEIN, 2008). 
O estudo da imunopatogênese por Hantavírus está mais avançado nos vírus que causam a SPCVH, pois não há um modelo animal para a síndrome com acometimento renal, limitando os estudos de imunologia para os vírus causadores da FHSR. No entanto, muitos detalhes dos mecanismos imunopatológicos de ambas as síndromes não estão bem conhecidos (SCHÖNRICH et al., 2008).

Apesar de conhecermos infecções agudas por Hantavírus apenas em casos de SPCVH, uma doença grave, supomos que estes mesmos vírus causem infecções humanas assintomáticas ou oligossintomáticas. Os fatores envolvidos no surgimento de doenças com diferentes gravidades não são conhecidos. Entretanto, supõe-se que polimorfismos genéticos ligados a HLA ou genes promotores de TNF, poderiam estar associados a distintas susceptibilidades ao Hantavírus (EASTERBROOK; KLEIN, 2008; BORGES et al., 2010).

O estudo da imunopatogenese da infecção por Hantavírus em roedores-reservatório é limitado por falta de marcadores específicos das múltiplas linhagens celulares envolvidas nas variadas espécies. No entanto, acredita-se que, por ativação de mecanismos supressores, a infecção por Hantavírus não produza respostas imunes exacerbadas nestes roedores, permitindo uma persistência viral. Esta persistência estaria associada a altos níveis de expressão de FOXP3 e da ação de células T regulatórias (EASTERBROOK; KLEIN, 2008; SCHÖNRICH et al., 2008), como é apresentado na Figura 6A.

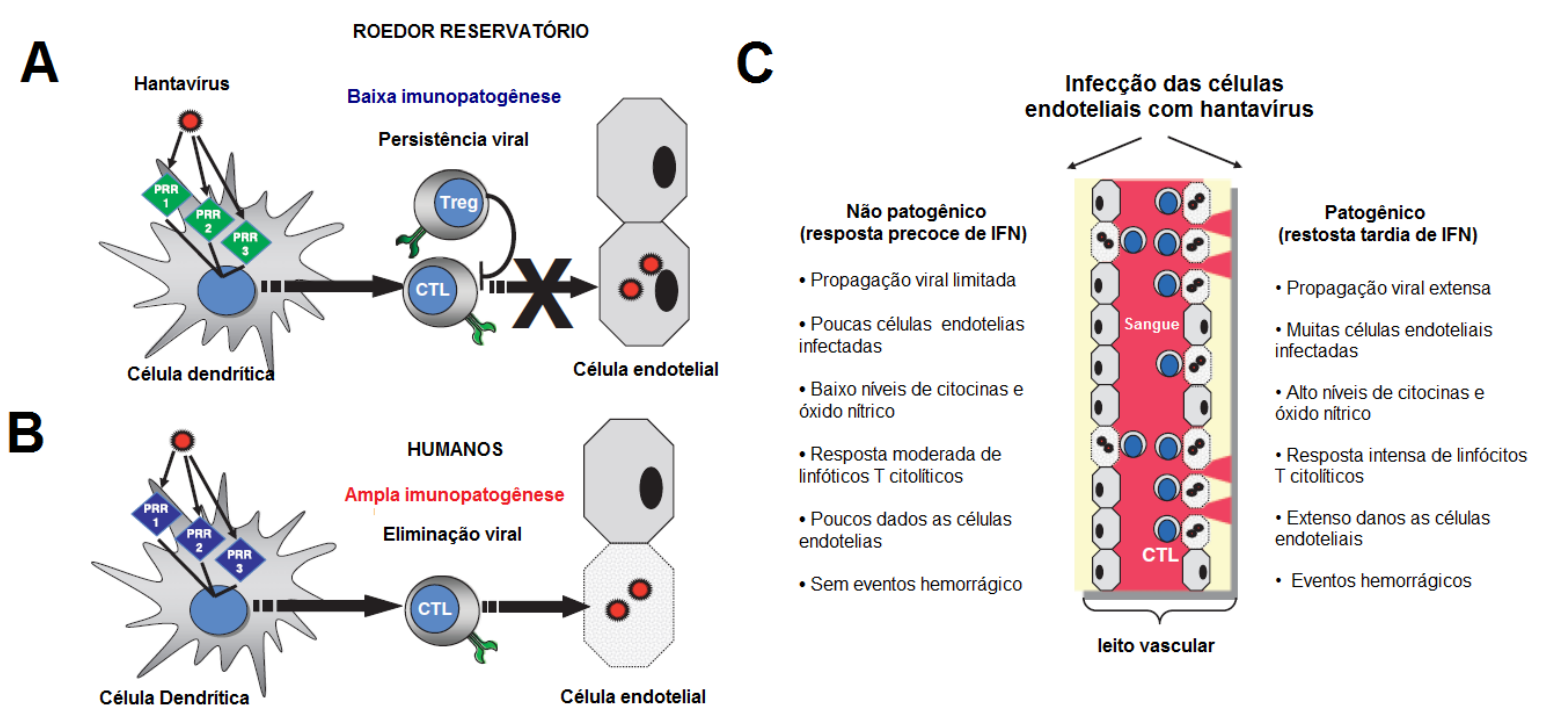

Figura 6. Diferença entre respostas imunes à infecção por Hantavírus em roedoresreservatório e em seres humanos. (A) Os Hantavírus, reconhecidos pelos receptores de reconhecimento padrão (PRR's) das células dendríticas, produzem uma estimulação de células $\mathrm{T}$ regulatórias que pode suprimir os linfócitos $\mathrm{T}$ citolíticos, reprimindo uma efetiva 
resposta imune e levando à persistência viral nos roedores. (B) As PRR's das células dendríticas humanas sinalizam para uma resposta antiviral com linfócitos $\mathrm{T}$ citolíticos e como consequência, as células endoteliais infectadas por Hantavírus são eliminadas levando graves doenças. (C) Fatores relacionados à imunopatogênese na infecção por Hantavírus. Fonte: SCHONRICH et al., 2008.

\subsection{TRANSMISSÃO}

Os Bunyaviridae são, em sua maioria, transmitidos por artrópodes. Fazem exceção os Hantavírus que infectam de forma persistente roedores-reservatório de espécies que variam segundo o vírus (ELLIOT, 2009). Os Hantavírus estão presentes na saliva dos roedores, provavelmente, durante toda a vida destes animais, encontrando-se em teores mais elevados entre o $10^{\circ}$ e o $20^{\circ}$ dias após a infecção. O local com maior concentração viral nos roedores são os pulmões, como mostrado na Figura 7 (EASTERBROOK; KLEIN, 2008). A excreção viral pelas fezes e urina tem início 2 a 3 semanas após a infecção atingindo teores mais elevados após 50 dias e provavelmente, persistindo por toda a vida do roedor (KORVA et al., 2009). Hantavírus nas excretas de roedores podem permanecer infectantes por vários dias, contudo, este período pode ser encurtado pela exposição à luz solar ou a agentes químicos, como detergentes (EASTERBROOK; KLEIN, 2008).

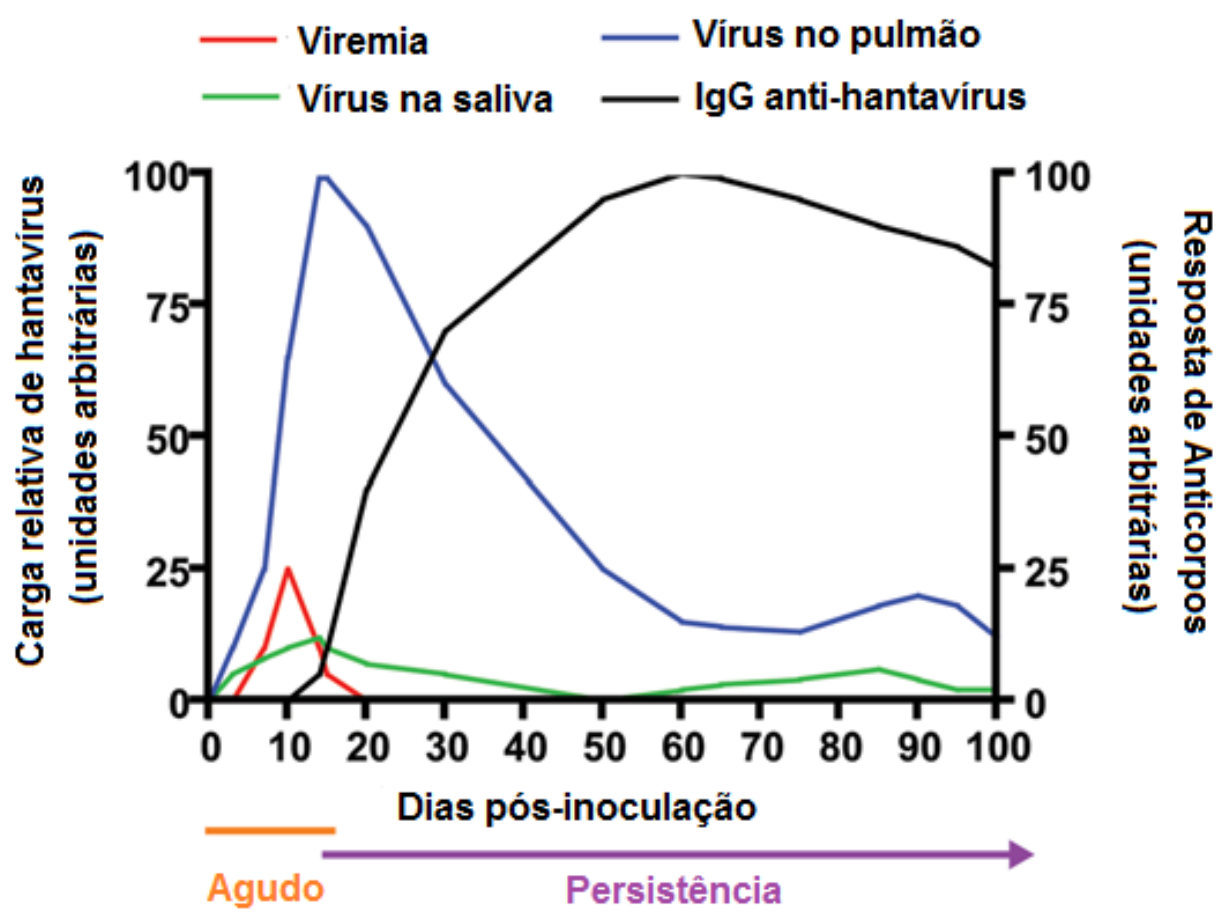

Figura 7. Cinética da infecção por Hantavírus em roedores. Fonte: EASTERBROOK; KLEIN, 2008. 
A via mais comum de infecção humana por Hantavírus é a inalação de partículas virais aerossolizadas, oriundas de excretas de roedores infectados (HJELLE, TORREZ, 2011). Outra rota de infecção humana é por contato físico direto com os roedores infectados, como quando ocorre mordedura (FIGUEIREDO et al., 2009A). A transmissão inter-humana de Hantavírus foi descrita apenas para o vírus Andes, na Argentina e no Chile, como apresentado na Figura 8 (PADULA et al., 1998; CHAPARRO et al., 1998; MARTINEZ et al., 2005).
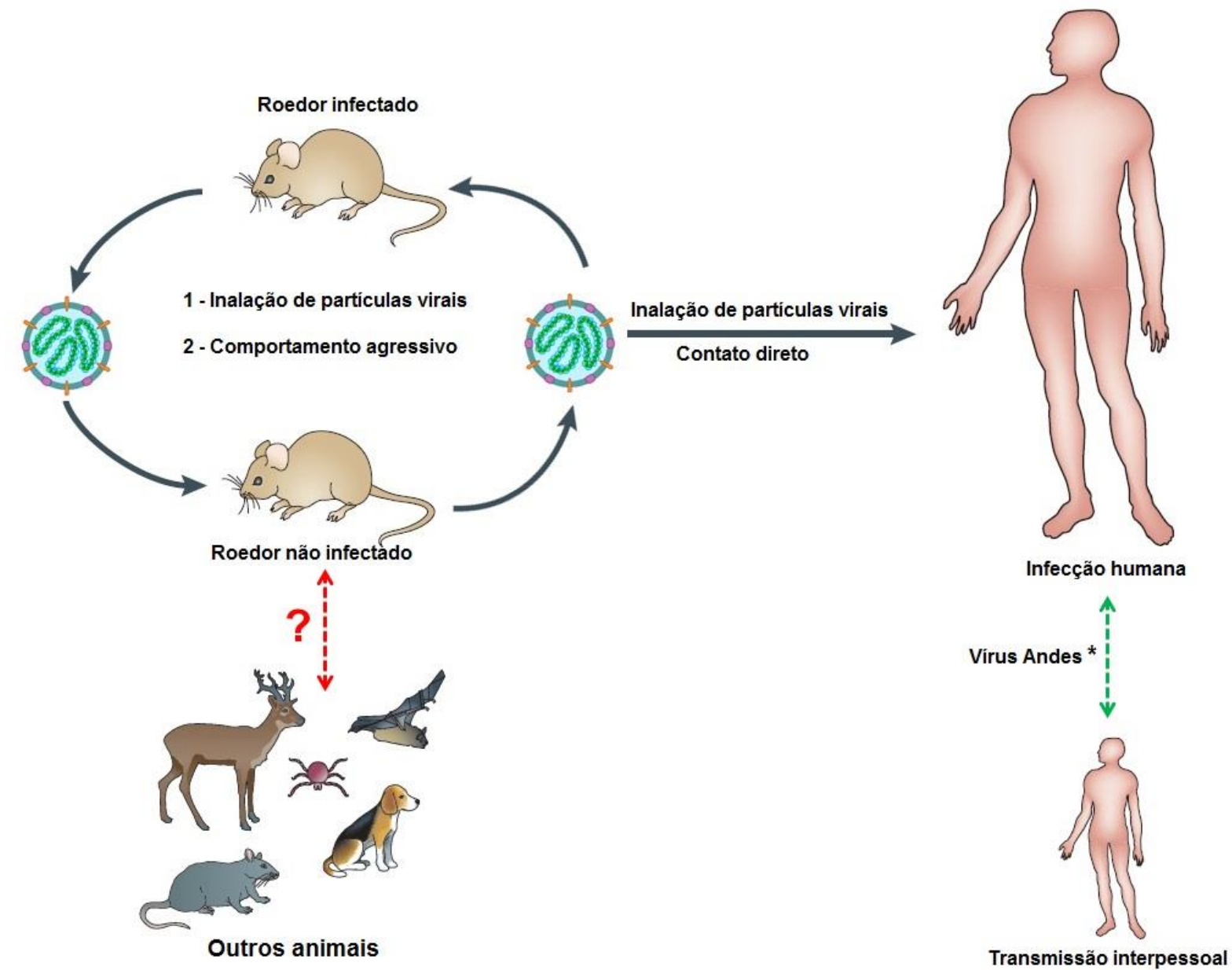

Figura 8. Transmissão dos Hantavírus entre roedores e envolvendo outros animais incluindo o homem.

Embora suponha-se que cada espécie de Hantavírus possua um roedor-reservatório específico, estudos mostram Hantavírus infectando roedores que não são considerados seus reservatórios naturais (HJELLE, TORREZ, 2011). Denomina-se a este fenômeno spillover. Este "pulo de espécie" já foi descrito para os vírus Juquitiba, Laguna-Negra, vírus Andes, Tula e Sin Nombre (DELFRARO et al., 2008; JONSSON, FIGUEIREDO, VAPALAHTI, 2010; SCHLEGEL et al., 2012). Na região de Ribeirão Preto, este evento foi observado com o vírus Araraquara, que tem como roedor-reservatório o Necromys lasiurus, porém foi encontrado o Hantavírus infectando roedores silvestres Akodon montesis, Calomys tender, 
Rhipdidomys sp e Oligoryzomys nigripes (SOUSA et al, 2008; FIGUEIREDO et al., 2009A; SABINO-SANTOS JR, 2010).

Além da transmissão entre diferentes espécies de roedores, existem Hantavírus associados a pequenos mamíferos insetívoros conhecidos como Musaranhos pertencentes à família Soricidae e Talpinae (JONSSON, FIGUEIREDO, VAPALAHTI, 2010). Além disso, anticorpos contra Hantavírus são observados em vários mamíferos como, alces, gatos, cães, raposas e morcegos, sendo que, nestes últimos, encontrou-se genoma viral (ZEIER et al. 2005; MALECKI et al., 2008; WEISS et al., 2012, DOBLY et al., 2012; GUO et al., 2013). Também, estudo norte-americano relatou a presença de RNA viral em ácaros (HOUCK et al., 2001) e outro, na Rússia, identificou Hantavírus em pássaros (SLONOVA et al., 1992), como exibido na Figura 8. No Brasil, recentemente foi identificado à presença de genoma viral em morcegos na cidade de Biritiba Mirin no estado de São Paulo (ARAUJO et al., 2012).

\subsection{ROEDORES-RESERVATÓRIO}

Os roedores são mamíferos pertencentes à ordem Rodentia, é a mais numerosa da classe Mammalia, possui cerca de 40 famílias, 389 gêneros e duas mil espécies, correspondendo a cerca de $40 \%$ das espécies de mamíferos existentes. Os roedores apresentam extraordinária capacidade de adaptação ecológica, além disso, possuem comportamentos sinantrópicos, estes fatores foram fundamentais para acompanhar o homem em seus deslocamentos pelo mundo ao longo de milhares de anos (BONVICINO, OLIVEIRA, D'ANDREA et al., 2008).

A distribuição eco-epidemiológica dos Hantavírus está relacionada à de seus roedores-reservatório. Hantavírus asiáticos e europeus possuem roedores-reservatório das subfamílias Murinae e Arvicolinae. Os Hantavírus americanos têm como principais reservatórios roedores das subfamílias Sigmodontine e Neotominae (MIR, 2010; JONSSON, FIGUEIREDO, VAPALAHTI, 2010; HJELLE, TORREZ, 2011).

$\mathrm{Na}$ América do Sul, os Hantavírus são relacionados com roedores da subfamilia Sigmodontinae, que é constituída por aproximadamente 380 espécies e 74 gêneros, distribuídos em toda a América do Sul, destes, 46 já foram identificados no Brasil (REIG, 1984; WILSON, REEDER, 2005; WEKSLER, PERCEQUILLO, 2006).

Os Sigmodontinae são sensíveis à modificação de seu habitat natural, contudo, algumas espécies, como Akodon azare, Akodon montensis e Necromy lasiurus, podem se adaptar a diferentes ambientes. Exemplo desta adaptação são as espécies Akodon sp e Necromys lasiurus observadas a conviver de modo comensal com seres humanos em sistemas 
agrícolas como o da cana-de-açúcar (Saccharum spp) e o do capim braquiária (Braqueara decumbis) (BONVICINO, OLIVEIRA, D'ANDREA et al., 2008). Fenômeno interessante na dinâmica populacional dos Sigmodontinae são os surtos em que a população torna-se abundante em curto espaço de tempo, as chamadas Ratadas (SABINO-SANTOS JR 2010).

No Brasil os roedores-reservatório associados a Hantavírus conhecidos são: Oligoryzomys nigripes (vírus Juquitiba); Necromys lasiurus (vírus Araraquara); Oligoryzomys moojeni e Oligoryzomys eliurus, anteriormente classificado como Oligoryzomys utiaritensis (vírus Castelo dos Sonhos); Calomys callosus e Calomys laucha (vírus Laguna Negra-like); Akodon montensis (vírus Jaborá); Oligoryzomys fornesi (vírus Anajatuba); Holochilus sciureus (vírus Rio Mearim) (SUZUKI et al., 2004; SOUSA et al., 2008; MENDES et al., 2001; TRAVASSOS DA ROSA et al, 2005; RABONI et al., 2009A; RABONI et al., 2009B; TRAVASSOS DA ROSA et al., 2011), como apresentado na Figura 2.

\subsection{DIAGNÓSTICO LABORATORIAL}

Dificulta o diagnóstico laboratorial das infecções por Hantavírus, particularmente quando se utilizam métodos em que o vírus é manuseado ou isolado, a exigência de que os procedimentos sejam realizados em laboratório com biossegurança nível três (BSL-3), que protegem contra eventuais dispersão de aerossóis deste microorganismo (ZEIR et al., 2005; MIR, 2010).

O período de incubação para infecções com hantavírus podem variar de 3 a 55 dias, sendo assim o método mais utilizado para diagnóstico laboratorial de infecções por Hantavírus é o ELISA (Enzyme-Linked Immunoabsorbent Assay), que detecta anticorpos IgM nos primeiros dias de doença. O ELISA, também, pode ser usado para detecção de anticorpos IgG em inquéritos soroepidemiológicos (ZEIR et al., 2005; MIR, 2010; JONSSON, FIGUEIREDO, VAPALAHTI, 2010). O antígeno de Hantavírus mais utilizado em ELISA é a nucleoproteína viral, que pode ser produzida pela metodologia do DNA recombinante (FIGUEIREDO et al, 2008; FIGUEIREDO et al, 2009B).

Também, o genoma de Hantavírus pode ser detectado em materiais clínicos utilizando a RT-PCR (Reverse Transcriptase-Polimerase Chain Reaction). Por RT-PCR pode-se amplificar parte de um dos segmentos genômicos de Hantavírus (MORELI et al, 2004). Nos últimos anos surgiu a RT-PCR em tempo real, que possibilita o diagnóstico e a determinação da carga de RNA viral e encontra-se disponível para alguns Hantavírus, tais como: Puumala, New York e Andes (TROMBLEY et al., 2004; NASLUND et al., 2011; ARAUJO et al., 2011). 
Outras técnicas utilizadas para diagnóstico de infecções por Hantavírus são: a imunoflorescência indireta, o Western blot, a neutralização, a hemaglutinação passiva, a imunohistoquímica e a hibridação (JONSSON, FIGUEIREDO, VAPALAHTI, 2010).

$\mathrm{O}$ isolamento de Hantavírus pode ser realizado por inoculação do material clínico em cultura de células Vero E6. Entretanto essa metodologia, além de necessitar laboratório BSL3 , é muito laboriosa pelos níveis lentos e baixos de replicação viral, além de produzir pouco ou nenhum efeito citopático nas células inoculadas (MIR, 2010).

\subsection{JUSTIFICATIVA}

O estudo dos Hantavírus é necessário no Brasil, dada a escassez de informações sobre este patógeno emergente que pode causar graves doenças e de alta letalidade. $\mathrm{O}$ diagnóstico precoce e rápido das infecções por Hantavírus é importante para que diante de um paciente com SPCVH, sejam tomadas medidas terapêuticas adequadas. O diagnóstico rápido permite tomar medidas para o controle de eventuais surtos por Hantavírus. Neste sentido, desenvolvemos como parte desta dissertação uma técnica de RT-PCR em tempo real, sensível e rápida, detectando e ainda, quantificando o Hantavírus infectante. Desta forma, possibilitamos correlacionar à carga viral com gravidade da doença e prognóstico.

A segunda parte desta dissertação refere-se a um estudo de bioinformática que versa sobre a filogeografia, a evolução histórica e a dinâmica dos Hantavírus. Estudar esta dinâmica permite melhor compreender o comportamento das distintas espécies de Hantavírus. Isto permite determinar fatores que promovem a transmissão e distribuição e também, orientar a caracterização e taxonomia destes vírus. O conhecimento das taxas evolutivas e da idade do ancestral comum mais recente permite inferir se a diversidade genômica dos Hantavírus resulta de uma evolução rápida ou lenta bem como, permite conhecer como ocorreu o espalhamento geográfico destes vírus ao longo do tempo. 


\section{OBJETIVO}

\subsection{OBJETIVOS GERAIS}

$\checkmark \quad$ Desenvolver uma RT-PCR em tempo real para detecção e quantificação do Hantavírus Araraquara e hantavírus sul-americanos;

$\checkmark \quad$ Realizar um estudo evolutivo dos Hantavírus associados a roedores.

\subsection{OBJETIVOS ESPECÍFICOS}

$\checkmark \quad$ Padronizar uma one-step RT- PCR em tempo real para Hantavírus Araraquara;

$\checkmark \quad$ Comparar aspectos da execução do teste e resultados obtidos com a one-step RT- PCR em tempo real para Hantavírus Araraquara com os da RT-PCR convencional;

$\checkmark \quad$ Analisar relações filogenéticas entre os Hantavírus associados a roedores;

$\checkmark \quad$ Determinar idade de ancestrais comuns mais recentes em cada grupo visando a conhecer como ocorreu a distribuição geográfica dos Hantavírus associados a roedores ao longo do tempo. 


\section{MATERIAL E MÉTODOS}

\subsection{DESENVOLVIMENTO DE UMA RT-PCR EM TEMPO REAL}

\subsubsection{Amostras}

Pacientes com sorologia positiva e/ou com presença de genoma de casos de SPCVH e amostras de tecido pulmonar de roedores infectados, armazenados a $-70^{\circ} \mathrm{C}$ no CPV-FMRPUSP foram utilizadas neste estudo. Todos haviam sido confirmadas quanto ao diagnóstico de infecção por Hantavírus por ELISA e/ou RT-PCR convencional, seguindo técnicas descritas anteriormente (FIGUEIREDO et al., 2008; MORELI et al., 2004).

\subsubsection{Extração do RNA viral}

O RNA viral destas amostras foi extraído utilizando o kit QIAamp (Qiagen, Hilden, Alemanha), de acordo com protocolo preconizado pelo fabricante. O RNA viral foi eluído em $50 \mu \mathrm{l}$ de água livre de RNase ao qual adicionaram-se 40 unidades de RNase-OUT (Invitrogen, Carlsbad, EUA) e armazenou-se a $-70^{\circ} \mathrm{C}$.

\subsubsection{RT-PCR e purificação do DNA}

Após a extração do RNA das amostras de pacientes com suspeita de SPCVH, estes extratos foram submetidos a RT-PCR utilizando primers que amplificam 264 pares de bases do segmento $\mathrm{S}$ do vírus Araraquara (MORELI et al., 2004). Dez $\mu$ do produto de amplificação foram submetidos à eletroforese em gel de agarose a 1,8\% e as bandas foram visualizadas em transiluminador, para confirmar a amplificação genômica viral. As bandas de amplificação foram recuperadas do gel de agarose e o DNA foi purificado utilizando kit QIAquick ${ }^{\circledR}$ Gel Extraction (Qiagen, Hilden, Alemanha), seguindo as recomendações do fabricante.

\subsubsection{Clonagem no plasmídeo}

Para a clonagem dos produtos de PCR utilizou-se o vetor pCR-TOPO 2.1 (Invitrogen, Carlsbad, EUA) que possui 3900 pb. A ligação foi realizada segundo as orientações do fabricante. O produto de ligação foi utilizado na transformação de células competentes de Escherichia coli.

\subsubsection{Transformação de células competentes}

Para a transformação, utilizaram-se células competentes das cepas de Escherichia coli DH5- $\alpha$ One Shot (Invitrogen, Carlsbad, EUA). Uma única colônia de bactéria foi 
inoculada em $10 \mathrm{ml}$ de meio LB líquido sem antibiótico e incubada a $37^{\circ} \mathrm{C}$ sob agitação de $200 \mathrm{rpm}$ durante 14 horas. Em seguida, $250 \mu \mathrm{l}$ desta solução de bactérias foram adicionados a $10 \mathrm{ml}$ de meio LB liquido (Luria-Bertan, contendo 10g/l Triptone, $5 \mathrm{~g} / \mathrm{l}$ de extrato de levedura, $171 \mathrm{mM}$ de $\mathrm{NaCl}$ ) sem antibiótico e incubou-se nas mesmas condições citadas anteriormente, por aproximadamente 2 horas, até atingir DO (densidade ótica) de 600nm. Posteriormente a cultura bacteriana foi armazenada no gelo por 10 minutos e centrifugou-se a $1000 \mathrm{rpm}$ durante 15 minutos por $4^{\circ} \mathrm{C}$.

Para ligação, utilizou-se sedimento bacteriano suspenso em 2,4 ml de uma mistura contendo $480 \mu \mathrm{l}$ de $\mathrm{CaCl}_{2}$ 0,1M. A esta mistura adicionaram-se $50 \mu \mathrm{l}$ de células competentes, e incubou-se a $42^{\circ} \mathrm{C}$ por 30 segundos e 2 minutos no gelo. Em seguida, adicionaram-se $250 \mu \mathrm{l}$ do meio SOC (Invitrogen, Carlsbad, EUA) e as células foram incubadas a $37^{\circ} \mathrm{C}$ sob agitação de $200 \mathrm{rpm}$ durante uma hora. Ao final, as células foram semeadas em placas de Petri contendo meio LB, ágar com kanamicina $(50 \mu \mathrm{g} / \mathrm{ml})$, X-Gal $(40 \mathrm{mg} / \mathrm{ml})$, IPTG (Isopropyl $\beta$-D1-thiogalactopyranoside) $(100 \mathrm{mM})$, sendo, incubadas a $37^{\circ} \mathrm{C}$ por 14 horas.

A seleção das colônias foi realizada com base na coloração das mesmas. Colônias azuis não contem plasmídeo com inserto e neste caso o IPTG induz a expressão da $\beta$ galactosidase que degrada o X-Gal, resultando na cor azul. As colônias brancas foram às escolhidas por conterem o plasmídeo com o inserto. Isto porque estando o inserto dentro do gene da $\beta$-galactosidase esta não degrada o X-Gal e a colônia bacteriana não muda de cor mantendo-se branca. Às colônias que continham o inserto adicionaram-se $100 \mathrm{ml}$ de meio LB com kanamicina $(50 \mu \mathrm{g} / \mathrm{ml})$, incubou-se a $37^{\circ} \mathrm{C}$ sob agitação de $200 \mathrm{rpm}$ durante 14 horas.

\subsubsection{Purificação dos plasmídeos}

As colônias bacterianas expandidas contendo o inserto foram submetidas à extração dos plasmídeos utilizando kit QIAprep Spin Miniprep (Qiagen, Hilden, Alemanha) e estes extratos foram submetidos à PCR convencional. Os produtos amplificados (amplicons) foram submetidos à eletroforese em gel de agarose 1\%, e as bandas que continham o tamanho esperado do plasmídeo contendo o inserto foram recortadas e purificadas usando o kit QIAquick Gel Extraction (Qiagen, Hilden, Alemanha). Posteriormente estes plasmídeos foram linearizados utilizando a enzima de restrição BamHI (Fermentas, Vilnius, Lituânia), de acordo com protocolo do fabricante. A linearização dos plasmídeos contendo o inserto foi verificada por eletroforese em gel de agarose $1 \%$, e estes foram armazenados em freezer a $-70^{\circ} \mathrm{C}$, para posterior transcrição in vitro. Os plasmídeos foram sequenciados para certificar a inserção do 
amplicon e confirmar a homologia do fragmento com sequências nucleotídicas do vírus Araraquara.

\subsubsection{Transcrição in vitro}

Um fragmento de $500 \mathrm{ng}$ do plasmídeo contendo o inserto, linearizado e purificado foram utilizados para transcrição in vitro com T7 RNA polimerase (Invitrogen, Carlsbad, EUA), segundo protocolo do fabricante. O volume final da reação, de $20 \mu \mathrm{l}$, foi mantido a $37^{\circ} \mathrm{C}$ por 4 horas e a ele acrescentou-se DNase I (Invitrogen, Carlsbad, EUA), incubando-se por 2 horas, para degradar todo o DNA plasmidial, segundo protocolo do fabricante. $\mathrm{O}$ amplicon gerado foi extraído utilizando o Kit QIAamp de extração para RNA viral (Qiagen, Hilden, Alemanha) e armazenado a $-70^{\circ} \mathrm{C}$.

Para verificar a pureza do RNA viral obtido pela transcrição in vitro, realizou-se eletroforese em gel de agarose a 1\%. Para tanto, por tratar-se de RNA, a cuba e os materiais envolvidos foram previamente lavados e incubados por 1 hora, em solução descontaminante contendo 1 litro de $\mathrm{H}_{2} \mathrm{O}$ DEPC (dietilpirocarbonato) estéril, $4 \mathrm{~mL}$ EDTA (ácido etilenodiamino tetra-acético) na concentração de $0,4 \%$ e $2 \mathrm{~mL}$ SDS (dodecilsulfato de sódio) na concentração de $0,2 \%$. Nestes materiais descontaminados, $10 \mu \mathrm{L}$ de cada transcrito foram submetidos à eletroforese em geral de agarose a $1 \%$ (acrescentado $20 \mu \mathrm{L} / \mathrm{mL}$ - isotiocianato de guanidina na concentração de $1 \mathrm{M}$ ), a 70 volts, durante 1 hora e 30 minutos. O RNA viral transcrito foi posteriormente quantificado utilizando o espectrofotômetro Thermo Scientific NanoDrop $^{\mathrm{TM}} 1000$ Spectrophotometer (NanoDrop Technologies, Wilmington, EUA).

\subsubsection{Padronização de uma one-step RT- PCR em tempo real}

O sistema SYBR Green baseia-se em um fluoróforo que ao se intercalar à dupla fita do DNA emite fluorescência, a qual pode ser detectada e quantificada. Na padronização desta técnica, utilizamos StepOnePlus ${ }^{\mathrm{TM}}$ Real-Time PCR Systems (Applied Biosystems, Foster City, EUA) e Kit SuperScript III Platinum One-Step qRT-PCR (Invitrogen, Carlsbad, EUA). Todas as reações foram realizadas em duplicata nas placas de 96 poços ou tubos de reação MicroAmp (Applied Biosystems, Foster City, EUA).

Diferentes parâmetros foram alterados para otimizar a reação, tais como: volume, concentração dos reagentes e condições de termociclagem. A especificidade dos produtos amplificados foi determinada analisando-se a curva de dissociação (ou temperatura de melting- $\mathrm{T}_{\mathrm{M}}$ ). Esta curva reflete a temperatura de dissociação da dupla fita de DNA quando o fluoróforo SYBR Green é liberado, durante a desnaturação, resultando em decréscimo do sinal 
de fluorescência. Isto determina que a amplificação das amostras positivas para o vírus Araraquara ocorre naquela $\mathrm{T}_{\mathrm{M}}$ específica.

Como controle do sinal de fluorescência utilizou-se o sistema SYBR Green I, um corante de referência interno de sinal $(R O X)$ que visa a evitar inespecíficas flutuações de fluorescência. $\mathrm{O} \triangle \mathrm{Rn}$ é calculado com base no sinal de fluorescência do SYBR Green I normalizado para o sinal de fluorescência da referência passiva $(R O X)$ em reação.

Todos os dados das reações foram analisados utilizando o programa StepOne 2.1 (Applied Biosystems, Foster City, EUA). O $\mathrm{C}_{\mathrm{T}}$ (cycle threshold), número de ciclos necessários para emitir o sinal fluorescência é inversamente proporcional à quantidade de RNA alvo amostral e é utilizado para fazer uma curva padrão para cada reação. Todos os amplicons obtidos durante a padronização da técnica foram submetidos à eletroforese em gel de agarose a 1,5\% para confirmar o tamanho do produto amplificado.

\subsubsection{Curva Padrão}

A curva padrão permite avaliar e quantificar o Hantavírus na amostra testada. Para a construção desta curva utilizamos RNA viral, produzido pela transcrição in vitro, sendo este previamente quantificado segundo sua densidade óptica (OD) a 260nm/280nm em espectrofotômetro Thermo Scientific NanoDrop ${ }^{\mathrm{TM}} 1000$ (NanoDrop Technologies, Wilmington, EUA). A concentração do RNA transcrito foi utilizada no cálculo da quantidade de cópias do RNA viral, pela seguinte fórmula: quantidade de cópias $=$ [Concentração $=$ resultado expresso pelo NanoDrop $(\mathrm{g} / \mathrm{mL}) /\left(\mathrm{n}^{\circ}\right.$ de pares de base do inserto até os corte da enzima de restrição x 340)] x Constante de Avogadro $\left(6,02 \times 10^{23}\right)$.

Após quantificar o número de cópias de RNA viral, este foi diluído na base 10, de $10^{3}$ a $10^{8}$ de cópias de RNA por $\mathrm{mL}$ e estas diluições foram submetidas à RT-PCR em tempo real visando a obter uma curva padrão do vírus Araraquara que permite, por analogia, quantificar o RNA viral presente em cada amostra testada.

\subsubsection{Limite de detecção}

Para conhecer o limite de detecção da one-step RT- PCR em tempo real para Hantavírus realizamos ensaios, em triplicata, com diluições decimais do RNA viral transcrito que continham de $3,7 \times 10^{11}$ a $3,7 \times 10^{-3}$ cópias de RNA por $\mathrm{mL}$. $\mathrm{O}$ ensaio foi repetido em diferentes dias, e nele verificamos os valores de $\mathrm{T}_{\mathrm{M}}$, slope e $\mathrm{R}_{2}$ em cada reação visando a verificar sua reprodutibilidade. 


\subsubsection{Especificidade}

Para avaliar a especificidade da one-step RT- PCR em tempo real para Hantavírus foi realizado ensaio com extratos de ácido nucleico de diversos vírus de RNA, como: Hantavírus Rio Mamoré, Coxsackie B5, Influenza A, Vírus Respiratório Sincicial Humano A, Parainfluenza-2, Metapneumovírus, Oropouche e Rinovírus-39. Todos, com exceção do primeiro, foram gentilmente cedidos por $\mathrm{Dr}^{\mathrm{a}}$. Miriã Ferreira Criado, Dr. José Luiz ProençaModena e Prof. Dr. Eurico Arruda Neto.

\subsubsection{Validação da RT- PCR em tempo real}

Validamos a one-step RT- PCR em tempo real para Hantavírus testando 20 amostras séricas de pacientes com suspeita de SPCVH e que possuíam IgG e/ou IgM contra a proteína $\mathrm{N}$ do vírus Araraquara e também, 7 outras amostras de pacientes com suspeita de SPCVH nas quais o genoma de Hantavírus foi detectado por RT- PCR convencional. Ainda, testamos nesta validação, 10 amostras do tecido pulmonar de roedores silvestres das quais cinco tiveram o genoma de Hantavírus detectado por RT-PCR convencional (SOUSA et al., 2008). As amostras tiveram RNA extraído pelo kit QIAamp (Qiagen, Hilden, Alemanha).

\subsection{ESTUDO EVOLUTIVO DOS HANTAVÍRUS ASSOCIADOS A ROEDORES}

\subsubsection{Base de dados com sequências de Hantavírus}

Para a realização das análises filogenéticas, foi coletada uma base de dados contendo todas as sequências completas do segmento $\mathrm{S}$ dos Hantavírus associados a roedores disponíveis no GenBank do National Center for Biotechnology Information (NCBI). Estes dados foram obtidos até 2 de setembro de 2012. O banco de dados contém as seguintes informações: código de acesso ao GenBank, ano de coleta, país de origem, cidade ou região da coleta, hospedeiro do vírus e referência bibliográfica (Apêndice A).

\subsubsection{Análise filogenética dos Hantavírus associados a roedores}

As sequências nucleotídicas de Hantavírus foram alinhadas e editadas utilizando o programa Clustal W (THOMPSON et al., 1994) disponível no programa BioEdit (HALL, 1999). Para as análises filogenéticas utilizamos apenas a região do segmento responsável por codificar a nucleoproteína. Portanto, excluímos desta análise as UTR's (untranslated region ou região não traduzida). Após alinhamento, as sequências foram analisadas no programa DAMBE 5.2.6 para excluir sequências idênticas (XIA; XIE, 2001). Em seguida, as sequências foram submetidas ao programa jModelTest visando identificar o melhor modelo de 
substituição de nucleotídeo para a construção de árvores filogenéticas. Este programa se baseia em três critérios estatísticos: o hLRT (hierarchical likelihood ratio tests), o AIC (Akaike Information Criterion) e o BIC (Bayesian Information Criterion) (POSADA, 2008). O critério utilizado para nossas análises filogenéticas foi o hLRT e o melhor modelo de substituição de nucleotídeos foi o GTR + G (General Time Reversible) com correção pela taxa de distribuição gamma $(\gamma)$ mais invariante (I) (RODRÍGUEZ et al., 1990).

A construção filogenética, utilizamos o método estatístico probabilístico, de máxima verossimilhança (Maximum Likelihood - ML). Este método estima a verossimilhança de um conjunto de dados representativos de um processo que realmente ocorreu. Neste caso, utilizamos o método GTR que considera taxas de substituição com base nos seis possíveis tipos reversíveis de substituições entre os nucleotídeos, utilizando o programa MEGA 5.2, apoiado estatisticamente por bootstrap que é a porcentagem de vezes em que o mesmo grupamento original foi recuperado nas árvores-réplicas e neste caso, o número foi de 1000 réplicas em ambas (KUMAR et al. 2008; TAMURA et al., 2011; YANG, RANNALA, 2012).

\subsubsection{Análise da divergência evolutiva}

Para conhecer a divergência genética entre os Hantavírus, as sequências nucleotídicas e aminoacídicas do segmento $\mathrm{S}$ foram ordenadas de acordo com a árvore geradas pelo método ML. As sequências aminoacídicas hipotéticas do segmento $S$ foram geradas por tradução de nucleotídeos para aminoácidos no programa MEGA 5.2 (KUMAR et al. 2008; TAMURA et al., 2011). As sequências foram submetidas à estimativa de divergência nucleotídica usando o método de p-distância ( $p$-distance), com o modelo da substituição de $d$ : Transitions + Transversions, com diferentes taxas de substituição entre os nucleotídeos. Desta forma, obtivemos distâncias médias entre clados e subclados (KUMAR et al. 2008; TAMURA et al., 2011).

\subsubsection{Filogeografia}

Taxa de mudanças evolutivas (substituição de nucleotídeos) e a idade do ancestral comum mais recente (ACMR), e a dispersão das espécies de Hantavírus pelo mundo foram determinadas utilizando o algoritmo bayesiano de Markov Chain Monte Carlo (MCMC), disponível no programa no BEAST v1. 7.4 (DRUMMOND et al., 2012 ). Uma matriz de localizações geográficas foi construída com base no local de amostragem para cada sequência. Para os conjuntos de dados foram utilizados modelos de relógio molecular relaxado, que assume as taxas de substituições entre os ramos iguais. O modelo demográfico de tamanho 
populacional constante foi o modelo de substituição de nucleotídeos GTR+G (General Time Reversible) usando um modelo de relógio molecular "relaxado" (uncorrelated Lognormal). A análise MCMC foi executada para $10 \times 10^{7}$ gerações e a convergência dos parâmetros (ESS>100) foram avaliadas com TRACER v1. 5. A estimativa dos parâmetros teve um intervalo de 95\% HPD (Highest Probability Density) (RODRÍGUEZ et al., 1990). Os programas TreeAnnotator v1. 5.2 e FigTree v1.1.2 (http//tree.bio.ed.ac.uk/software/figtree/) foram utilizados para analises dos dados e visualizar árvore com Maximum Clade Credibility (MCC). Além disso, utilizamos o programa BayesTraits para estimar a probabilidade posterior da posição dos galhos e poder determinar a localização geográfica mais plausível destes galhos. 


\section{RESULTADOS}

\subsection{DESENVOLVIMENTO DE UMA RT-PCR EM TEMPO REAL}

\subsubsection{Produção do RNA transcrito}

Um fragmento de $264 \mathrm{pb}$ correspondente ao segmento $\mathrm{S}$ do Hantavírus Araraquara, foi amplificado conforme protocolo desenvolvido previamente (MORELI et al., 2004). Em seguida o fragmento foi purificado e inserido no vetor de clonagem pCR-TOPO 2.1 e o produto desta ligação com o vetor foi utilizado para transformar células competentes de Escherichia coli.

As colônias contendo o inserto foram selecionadas segundo a coloração, crescidas e posteriormente tiveram o plasmídeo com inserto purificado. Estes plasmídeos foram submetidos a sequenciamento de nucleotídeos para confirmar a inserção do fragmento do segmento $\mathrm{S}$ do Hantavírus Araraquara, demonstrando uma homologia de $99 \%$ com a sequência do segmento $\mathrm{S}$ de Hantavírus Araraquara (EF571895). Os plasmídeos purificados foram linearizados utilizando a enzima de restrição BamHI e posteriormente utilizados para transcrição in vitro.

\subsubsection{RT-PCR em tempo real}

Diferentes parâmetros foram avaliados para aperfeiçoar a one-step RT-PCR em tempo real utilizando o sistema SYBR Green I, como mostrado na Tabela 1. Com base nos resultados obtidos, a condição ideal para amplificação do fragmento do genoma do segmento $\mathrm{S}$ dos hantavírus deve conter: $2 \mu \mathrm{l}$ de amostra de RNA; $0.5 \mu \mathrm{l}$ de $\mathrm{MgSO}_{2} ; 0.35 \mu \mathrm{l}$ de cada primer $(10 \mathrm{mM}) ; 10 \mu \mathrm{l}$ de SYBR buffer $(2 \mathrm{x}) ; 0.5 \mu \mathrm{l}$ de SuperScript III Platinum e 7,7 $\mu \mathrm{l}$ de água MilliQ em um volume final de $20 \mu$. Mostrou-se como termociclagem ideal: $50^{\circ} \mathrm{C}$ por 20 minutos para a produção de cDNA, $95^{\circ} \mathrm{C}$ por 5 minutos para ativar a $T a q$ polimerase e separar a fita dupla de DNA, e 45 ciclos de $95^{\circ} \mathrm{C}$ por 15 segundos, para desnaturação, $55^{\circ} \mathrm{C}$ por 25 segundos para anelamento dos primers e $72^{\circ} \mathrm{C}$ por 35 segundos para extensão.

Tabela 1. Parâmetros que tiveram variações experimentadas visando a otimizar a one-step RT-PCR em tempo real.

\begin{tabular}{ccccccc}
\hline Teste & $\begin{array}{c}\text { Transcrito } \\
\text { do RNA } \\
\text { viral }\end{array}$ & $\begin{array}{c}\mathbf{M g S O}_{2} \\
\mathbf{m M}\end{array}$ & $\begin{array}{c}\text { Volume e } \\
\text { concentração dos } \\
\text { primer }\end{array}$ & $\begin{array}{c}\text { Volume } \\
\text { Final }\end{array}$ & $\begin{array}{c}\text { Temperatura e } \\
\text { Tempo da RT }\end{array}$ & Ciclos Térmicos \\
\hline $\mathbf{1}$ & $1 \mu \mathrm{l}$ & $2 \mu \mathrm{l}$ & $1 \mu \mathrm{l}(20 \mathrm{mM})$ & $25 \mu \mathrm{l}$ & $\begin{array}{c}50^{\circ} \mathrm{C} \text { por } 15 \\
\text { min }\end{array}$ & $\begin{array}{c}95^{\circ} \mathrm{C} \text { por } 5 \text { min seguido } \\
40 \text { ciclos de } 95^{\circ} \mathrm{C}(15 \mathrm{~s}) ; \\
60{ }^{\circ} \mathrm{C}(25 \mathrm{~s}) \mathrm{e} 72^{\circ} \mathrm{C}\end{array}$ \\
\hline
\end{tabular}




\begin{tabular}{|c|c|c|c|c|c|c|}
\hline & & & & & & $(35 s)$. \\
\hline 2 & $1 \mu \mathrm{l}$ & $\begin{array}{c}2 \mu \mathrm{l} \\
(25 \mathrm{mM})\end{array}$ & $0,5 \mu \mathrm{l}(20 \mathrm{mM})$ & $25 \mu \mathrm{l}$ & $\begin{array}{c}50^{\circ} \mathrm{C} \text { por } 15 \\
\text { min }\end{array}$ & $\begin{array}{l}95^{\circ} \text { por } 5 \text { min seguido } 40 \\
\text { ciclos de } 95^{\circ} \mathrm{C}(15 \mathrm{~s}) ; 60 \\
{ }^{\circ} \mathrm{C}(25 \mathrm{~s}) \text { e } 72^{\circ} \mathrm{C}(35 \mathrm{~s}) .\end{array}$ \\
\hline 3 & $1 \mu \mathrm{l}$ & $\begin{array}{c}1 \mu \mathrm{l} \\
(25 \mathrm{mM})\end{array}$ & $0,5 \mu \mathrm{l}(20 \mathrm{mM})$ & $25 \mu \mathrm{l}$ & $\begin{array}{c}50^{\circ} \mathrm{C} \text { por } 15 \\
\text { min }\end{array}$ & $\begin{array}{l}95^{\circ} \text { por min seguido } 40 \\
\text { ciclos de } 95^{\circ} \mathrm{C}(15 \mathrm{~s}) ; 60 \\
{ }^{\circ} \mathrm{C}(25 \mathrm{~s}) \text { e } 72{ }^{\circ} \mathrm{C}(35 \mathrm{~s}) .\end{array}$ \\
\hline 4 & $1 \mu \mathrm{l}$ & $\begin{array}{c}1 \mu \mathrm{l} \\
(25 \mathrm{mM})\end{array}$ & $0,5 \mu \mathrm{l}(20 \mathrm{mM})$ & $20 \mu \mathrm{l}$ & $\begin{array}{c}50^{\circ} \mathrm{C} \text { por } 15 \\
\text { min }\end{array}$ & $\begin{array}{c}95^{\circ} \text { por min seguido } 40 \\
\text { ciclos de } 40 \text { ciclos de } 95 \\
{ }^{\circ} \mathrm{C}(15 \mathrm{~s}) ; 55^{\circ} \mathrm{C}(25 \mathrm{~s}) ; \\
72^{\circ} \mathrm{C}(35 \mathrm{~s})\end{array}$ \\
\hline 5 & $2 \mu 1$ & $\begin{array}{c}0,5 \mu \mathrm{l} \\
(25 \mathrm{mM})\end{array}$ & $0,35 \mu \mathrm{l}(10 \mathrm{mM})$ & $20 \mu l$ & $\begin{array}{c}50^{\circ} \mathrm{C} \text { por } 20 \\
\text { min }\end{array}$ & $\begin{array}{c}95^{\circ} \text { por min seguido } 40 \\
\text { ciclos de } 40 \text { ciclos de } \\
95^{\circ} \mathrm{C}(15 \mathrm{~s}) ; 58^{\circ} \mathrm{C}(25 \mathrm{~s}) \\
72^{\circ} \mathrm{C}(35 \mathrm{~s})\end{array}$ \\
\hline 6 & $2 \mu \mathrm{l}$ & $\begin{array}{c}0,5 \mu \mathrm{l} \\
(25 \mathrm{mM})\end{array}$ & $0,35 \mu \mathrm{l}(10 \mathrm{mM})$ & $20 \mu \mathrm{l}$ & $\begin{array}{c}50^{\circ} \mathrm{C} \text { por } 20 \\
\text { min }\end{array}$ & $\begin{array}{l}95^{\circ} \text { por } 5 \text { min seguido de } \\
40 \text { ciclos de } 95^{\circ} \mathrm{C}(15 \mathrm{~s}) ; \\
55^{\circ} \mathrm{C}(25 \mathrm{~s}) ; 72^{\circ} \mathrm{C}(35 \mathrm{~s}) .\end{array}$ \\
\hline $\begin{array}{l}\text { Reação } \\
\text { Ideal }\end{array}$ & $2 \mu \mathrm{l}$ & $\begin{array}{c}0,5 \mu \mathrm{l} \\
(25 \mathrm{mM})\end{array}$ & $0,35 \mu \mathrm{l}(10 \mathrm{mM})$ & $20 \mu \mathrm{l}$ & $\begin{array}{c}50^{\circ} \mathrm{C} \text { por } 20 \\
\text { min }\end{array}$ & $\begin{array}{l}95^{\circ} \text { por } 5 \text { min seguido de } \\
40 \text { ciclos de } 95^{\circ} \mathrm{C}(15 \mathrm{~s}) ; \\
55^{\circ} \mathrm{C}(25 \mathrm{~s}) ; 72^{\circ} \mathrm{C}(35 \mathrm{~s}) .\end{array}$ \\
\hline
\end{tabular}

\subsubsection{Curva padrão}

Para a construção de uma curva padrão, determinou-se o número de moléculas do RNA viral transcrito resultando em $3,7 \times 10^{11}$ cópias por mL. Diluições seriadas do RNA viral transcrito foram utilizadas para a construção da curva padrão da RT-PCR em tempo real, como mostrado na Figura 9. Os ciclos de amplificação entre as diferentes diluições indicam uma distância proporcional às diluições.

Os parâmetros da one-step RT-PCR em tempo real utilizando o transcrito de RNA viral para a construção da curva padrão foram: slope de -3,075 (o valor ideal é -3,200), percentual de eficiência (EFF) de $111,4 \%$ e coeficiente de correlação $\left(R_{2}\right)$ 0,995 (sendo considerado ideal o valor <1,0), conforme apresentado na Figura 9B.

$\mathrm{O}$ nível de $\Delta \mathrm{Rn}$ é utilizado para a determinar o ciclo limiar (threshold cycle $-\mathrm{C}_{\mathrm{T}}$ ), o qual é fixado como o nível acima da linha de base suficiente para o crescimento exponencial da curva de amplificação. Para a curva padrão este limiar (valor inicial) foi de 0.055305 . Podemos observar que quanto maior a quantidade de ácidos nucléicos alvo, menor será o número de ciclos necessários para a amplificação, como mostra a Figura 9A.

$\mathrm{O} \mathrm{C}_{\mathrm{T}}$ é definido como o número de ciclos necessários para o sinal de fluorescência ser emitido, sendo superior ao limite basal do sistema. Os níveis de $\mathrm{C}_{\mathrm{T}}$ são inversamente proporcionais à quantidade de ácido nucleico alvo na amostra, ou seja, o nível mais baixo do $\mathrm{C}_{\mathrm{T}}$ relaciona-se a maior quantidade de ácido nucleico alvo na amostra, conforme e indicado na Figura 10B. 


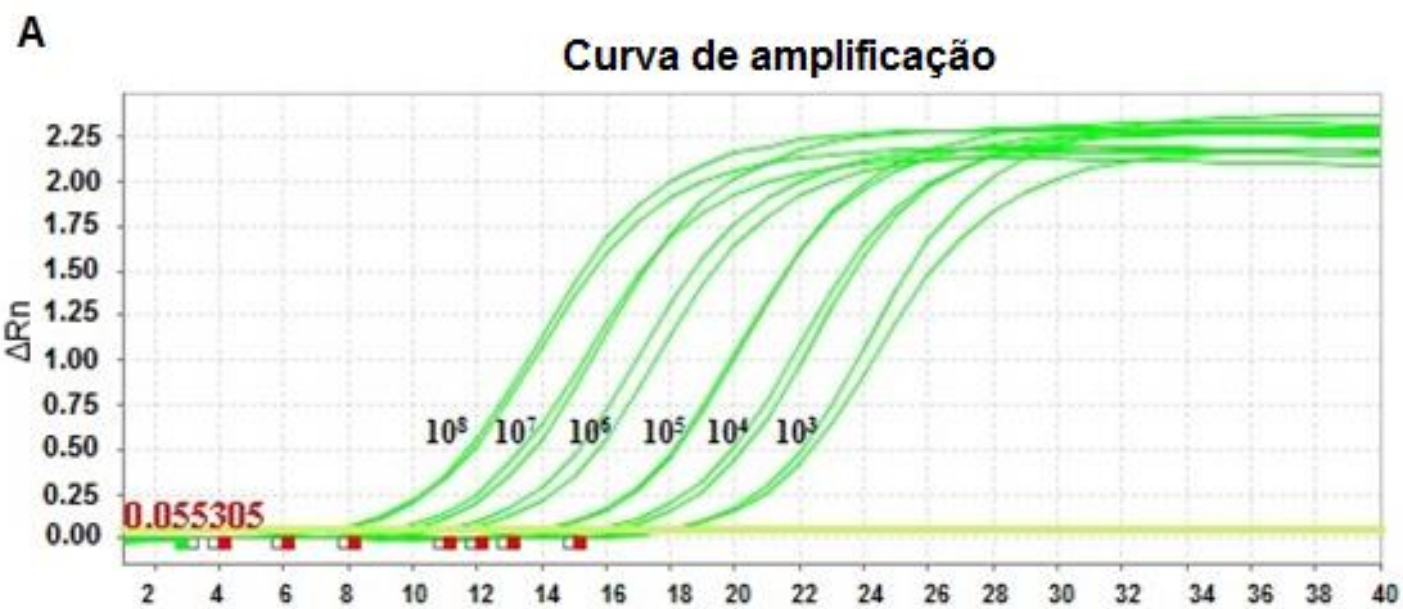

B

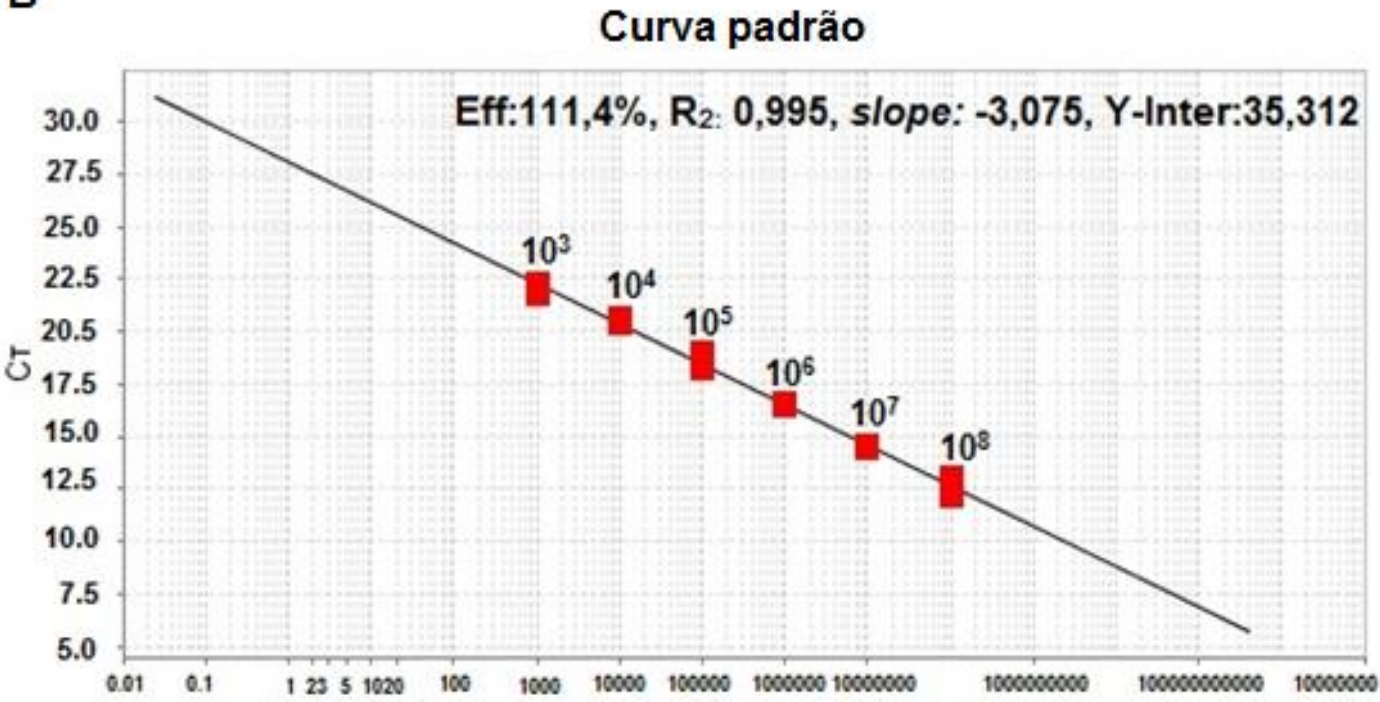

Figura 9. Temperatura de melting da one-step RT-PCR em tempo real para vírus Araraquara. (A) Curva de amplificação construída com diluições de $10^{8}$ a $10^{3}$ cópias por $\mathrm{mL}$ do transcrito de RNA do vírus Araraquara. (B) Curva padrão construída a partir das diluições decimais do transcrito associada ao parâmetro CT.

Análise da curva de melting permite mensurar a dissociação da dupla hélice de DNA durante o aquecimento, pois à medida que a temperatura aumenta a dupla fita começa a dissociar levando a um aumento na intensidade de fluorescência. A temperatura em que 50\% do DNA é denaturado é conhecido como o ponto de fusão (melting point ou temperature mentilng - $\mathrm{T}_{\mathrm{M}}$ ). A $\mathrm{T}_{\mathrm{M}}$ é usada para avaliar a especificidade deste ensaio com um fragmento de $264 \mathrm{pb}$ do segmento $\mathrm{S}$ do Hantavírus Araraquara, já que o pico de dissociação específico ocorrerá normalmente na mesma temperatura em todas as reações. Em nosso ensaio observamos que a reação com RNA transcrito, bem como com amostras humanas e de 
roedores, foram consideradas positivas quando exibiram $\mathrm{T}_{\mathrm{M}}$, entre $80,83 \pm 0,89^{\circ} \mathrm{C}$, como mostra a Figura 10.

A

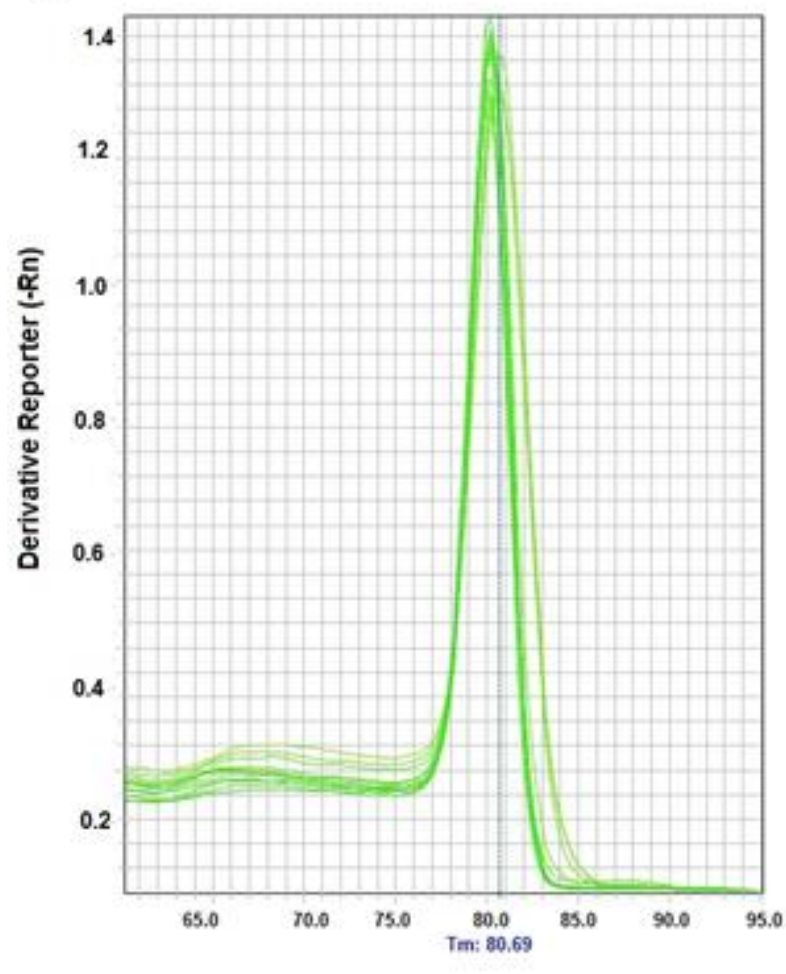

B

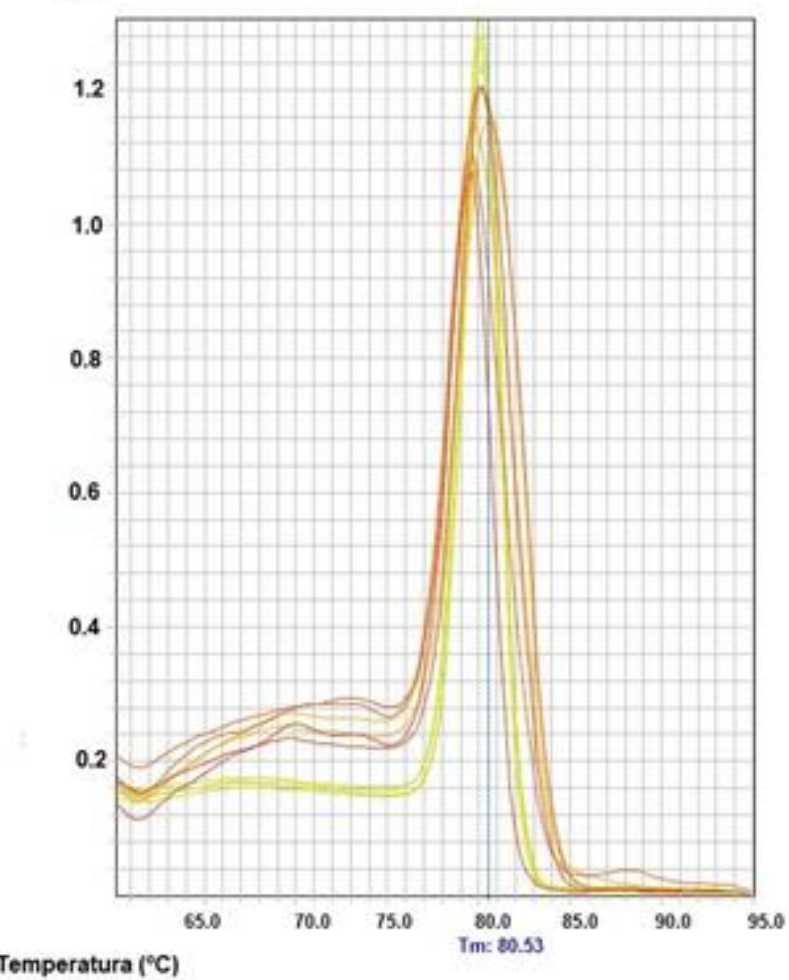

Figura 10. Curva de melting da one-step RT-PCR em tempo real para vírus Araraquara (A) $\mathrm{T}_{\mathrm{M}}$ da RT-PCR em tempo real, obtidos a partir de transcritos do RNA do vírus Araraquara, $10^{3}$ a $10^{8}$ cópias $/ \mathrm{mL}$. (B) $\mathrm{T}_{\mathrm{M}}$ de amostras positivas (vermelho) e curva padrão (amarelo). Todas as curvas de melting foram semelhantes, indicando tratar-se de um ensaio reprodutível.

\subsubsection{Limite de detecção}

A sensibilidade da técnica foi avaliada em ensaios nos quais testou-se em triplicata diluições logarítmicas do transcrito do RNA viral com valores entre $3.7 \times 10^{11}$ cópias por $\mathrm{mL}$ a $3,7 \times 10^{-3}$ cópias por $\mathrm{mL}$. Dez cópias por $\mathrm{mL}$ foi o limite de detecção desta RT-PCR em tempo real, pois a menor concentração permaneceu dentro dos valores determinados como:

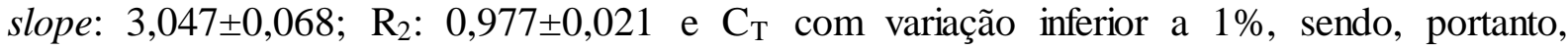
variações que não interferiram na confiabilidade do ensaio.

\subsubsection{Especificidade}

A especificidade da RT-PCR em tempo real para o Hantavírus Araraquara foi avaliada testando extratos de RNA dos vírus Coxsackie B5, Influenza A, Vírus Respiratório Sincicial Humano A, Parainfluenza-2, Metapneumovírus, Oropouche e Rinovírus-39. Não 
observou-se a amplificação genômica destes vírus na $\mathrm{T}_{\mathrm{M}}$ indicada para $\mathrm{o}$ Hantavírus Araraquara. No entanto observamos amplificação do genoma do Hantavírus Rio Mamoré na mesma $\mathrm{T}_{\mathrm{M}}$ do Hantavírus Araraquara.

\subsubsection{Validação da RT- PCR em tempo real}

A one-step RT-PCR em tempo real foi capaz de detectar genoma de Hantavírus em todas as amostras positivas pela técnica convencional. Além disso, duas amostras séricas de paciente negativas pela RT-PCR convencional foram positivas pela RT-PCR em tempo real, como apresentado na Tabela 2. Também, 5 amostras de tecido pulmonar de roedores silvestres foram confirmadas e quantificadas pelo ensaio em tempo real, conforme e apresentado na Tabela 3.

Tabela 2. Comparação da RT-PCR convencional com a RT-PCR em tempo real na detecção do Hantavírus Araraquara em materiais clínicos de origem humana e de roedor.

\begin{tabular}{ccccc}
\hline ELISA & Título de IgG & $\begin{array}{c}\text { RT-PCR } \\
\text { Convencional }\end{array}$ & $\begin{array}{c}\text { One-step RT-PCR } \\
\text { em tempo real } \\
\text { SY BR Green I }\end{array}$ \\
\hline H1 & IgG & 12,800 & Negativo & Negativo \\
\hline H2 & IgG & 12,800 & Negativo & Negativo \\
\hline H3 & IgG & 6,400 & Positivo & $6,93 \times 10^{5}$ cópias $/ \mathrm{mL}$ \\
\hline H4 & IgG & 1,600 & Negativo & Negativo \\
\hline H5 & IgG & 12,800 & Positivo & $8,85 \times 10^{2}$ cópias $/ \mathrm{mL}$ \\
\hline H6 & IgG & 12,800 & Positivo & $1,06 \times 10^{4}$ cópias/ $\mathrm{mL}$ \\
\hline H7 & IgG e IgM & 3,200 & Negativo & $1,03 \times 10^{2}$ cópias $/ \mathrm{mL}$ \\
\hline H8 & IgG e IgM & 6,400 & Negativo & Negativo \\
\hline H9 & IgG e IgM & 6,400 & Positivo & $2,72 \times 10^{5}$ cópias/ $\mathrm{mL}$ \\
\hline H10 & IgG and IgM & 12,800 & Negativo & Negativo \\
\hline H11 & IgG & 400 & Negativo & $7,4 \times 10^{1}$ cópias $/ \mathrm{mL}$ \\
\hline H12 & IgG & 400 & Positivo & $1,55 \times 10^{5}$ cópias/ $\mathrm{mL}$ \\
\hline H13 & IgG and IgM & 3,200 & Positivo & $1,34 \times 10^{5}$ cópias/ $\mathrm{mL}$ \\
\hline H14 & IgG and IgM & 3,200 & Positivo & $8,72 \times 10^{2}$ cópias/ $\mathrm{mL}$ \\
\hline H15 & IgG and IgM & 6,400 & Negativo & Negativo \\
\hline H16 & IgG and IgM & 12,800 & Positivo & $3,87 \times 10^{5}$ cópias/ $\mathrm{mL}$ \\
\hline H17 & IgG & 3,200 & Negativo & Negativo \\
\hline H18 & IgG & 3,200 & Negativo & Negativo \\
\hline H19 & IgG & 400 & Negativo & Negativo \\
\hline H20 & IgG & 12,800 & Negativo & Negativo \\
\hline N1 & não realizado & não realizado & Positivo & $1,39 \times 10^{3}$ cópias $/ \mu g$ \\
\hline N2 & não realizado & não realizado & Negativo & Negativo \\
\hline N3 & não realizado & não realizado & Positivo & $8,9 \times 10^{4}$ cópias $/ \mu g$ \\
\cline { 2 - 5 } & & & & \\
\hline
\end{tabular}




\begin{tabular}{ccccc}
\hline N4 & não realizado & não realizado & Positivo & $1,32 \times 10^{4}$ cópias $/ \mu \mathrm{g}$ \\
\hline N5 & não realizado & não realizado & Negativo & Negativo \\
\hline N6 & não realizado & não realizado & Negativo & Negativo \\
\hline N7 & não realizado & não realizado & Negativo & Negativo \\
\hline N8 & não realizado & não realizado & Positivo & $1,78 \times 10^{3}$ cópias/ $\mu \mathrm{g}$ \\
\hline N9 & não realizado & não realizado & Negativo & Negativo \\
\hline N10 & não realizado & não realizado & Positivo & $2,68 \times 10^{2}$ cópias $/ \mu \mathrm{g}$ \\
\hline
\end{tabular}

Legenda: H: Soro humano, N: Pulmão de Necromys lasiurus. ${ }^{1}$ Titúlos expressos em cópias/ $\mathrm{mL}$ ou cópias/ $\mu \mathrm{g}$ de RNA viral

\subsection{ESTUDO EVOLUTIVO DOS HANTAVÍRUS ASSOCIADOS A ROEDORES}

\subsubsection{Base de dados}

O total de sequências nucleotídicas utilizadas para a análise, excluindo sequências idênticas ou clones, foi de 252 do segmento S, obtidas entre 1985 e 2010, identificadas em 30 países distribuídos em todos os continentes, exceto Oceania, como apresentado na Tabela 3.

Tabela 3. Países, número e ano das sequências nucleotídicas do segmento $\mathrm{S}$ dos Hantavírus associados a roedores.

\begin{tabular}{ccc}
\hline Países & $N$ & Ano das Amostras \\
Alemanha & 15 & $1997-2008$ \\
Finlândia & 3 & $1991-2000$ \\
Suécia & 16 & $2004-2005$ \\
Eslováquia & 6 & $2001-2004$ \\
Croácia & 1 & 2000 \\
Polônia & 2 & 1995 \\
Grécia & 3 & 1999 \\
República Tcheca & 1 & 1995 \\
Dinamarca & 1 & 2000 \\
Sérvia & 1 & 1997 \\
Letônia & 5 & $2000-2008$ \\
\hline Peru & 1 & 1996 \\
Brasil & 16 & $2001-2006$ \\
Argentina & 11 & $1997-1999$ \\
Chile & 4 & $1997-1999$ \\
Bolívia & 5 & $1992-2008$ \\
Venezuela & 1 & 1994 \\
Paraguai & 4 & $1995-2000$ \\
\hline EUA & 11 & $1985-2006$ \\
Panamá & 1 & 200 \\
México & 8 & 2006
\end{tabular}




\begin{tabular}{ccc} 
Costa Rica & 1 & 1989 \\
\hline Guine & 2 & 2004 \\
\hline China & 85 & $1986-2007$ \\
Rússia & 21 & $1993-2005$ \\
Coreia do Sul & 10 & $1997-2009$ \\
Cazaquistão & 1 & 1995 \\
Japão & 10 & $1995-2010$ \\
Tailândia & 2 & $1998-2004$ \\
Cingapura & 4 & 2006 \\
\hline TOTAL & $\mathbf{2 5 2}$ & $\mathbf{1 9 8 5 - 2 0 1 0}$ \\
\hline
\end{tabular}

\subsubsection{Análises filogenéticas dos Hantavírus associados a roedores}

A reconstrução filogenética mostrou em sua topologia uma divisão evolutiva inicial em dois grandes clados de Hantavírus associados às familias de roedores Cricetidae (subfamilias Arvicolinae, Neotominae e Sigmodontinae) e a familia de roedores Muridae (subfamília Murinae). Estes dois grandes grupos podem ser subdivididos em subclados, nomeados segundo as subfamilias de roedores-reservatórios em que estes vírus foram identificados, como mostra a Figura 11.

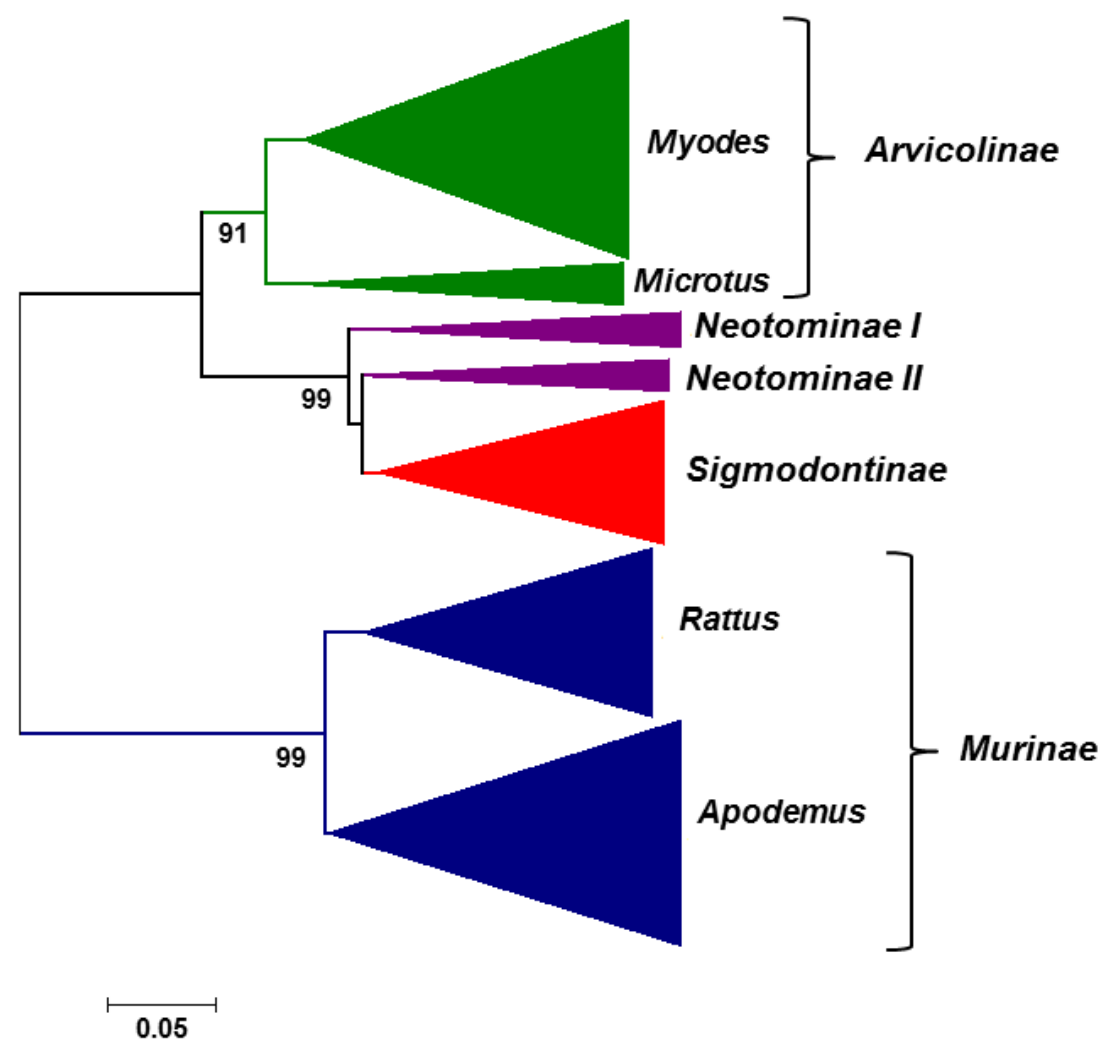

Figura 11. Árvore filogenética usando o método de Maximum Likelihood do segmento $\mathrm{S}$ dos Hantavírus. O modelo evolutivo utilizado foi o General Time Reversible com correção de 
gamma $(\gamma)$ de $0.6290(\mathrm{GTR}+\mathrm{G})$. As análises foram suportadas utilizando o teste estatístico de bootstrap de 1000 réplicas e os valores estão indicados nos principias ramos.

\subsubsection{Divergência filogenética entre Hantavírus associados às subfamílias de roedores}

Para melhor conhecer a diferença filogenética entre os grupos exibidos nas árvores, analisamos a divergência evolutiva baseada no alinhamento individual das sequências completas, é foi determinando a divergência média e frequência. A divergência média nucleotídica entre os Hantavírus associados a subfamilias de roedores reservatórios foi entre $21 \%$ e $34 \%$ para nucleotídeos e de $10 \%$ a $32 \%$ para aminoácidos, como apresentado na Tabela 4 e Figura 12.

Tabela 4. Estimativa média de divergência evolutiva entre os grupos de Hantavírus com base em nucleotídeos e aminoácidos do segmento $\mathrm{S}$.

\begin{tabular}{|c|c|c|c|c|}
\hline \multirow[b]{2}{*}{ Grupos } & \multicolumn{2}{|c|}{ NUCLEOTÍDEOS } & \multicolumn{2}{|c|}{ AMINOÁCIDOS } \\
\hline & $\begin{array}{c}\text { Divergência } \\
(\%)\end{array}$ & $\begin{array}{c}\text { Des vio } \\
\text { Padrão } \\
(\%)\end{array}$ & $\begin{array}{c}\text { Divergência } \\
(\%)\end{array}$ & $\begin{array}{c}\text { Des vio } \\
\text { Padrão } \\
(\%)\end{array}$ \\
\hline Arvicolinae vs Neotominae & 27,70 & 0,92 & 21,50 & 1,40 \\
\hline Arvicolinae vs Sigmodontinae & 27,90 & 0,96 & 20,90 & 1,56 \\
\hline Arvicolinae vs Murinae & 33,90 & 0,99 & 31,90 & 1,62 \\
\hline Neotominae vs Sigmodontinae & 21,80 & 0,83 & 10,70 & 0,93 \\
\hline Neotominae vs Murinae & 34,70 & 1,04 & 31,80 & 1,62 \\
\hline Sigmodontinae vs Murinae & 34,00 & 1,03 & 30,80 & 1,58 \\
\hline
\end{tabular}

\subsubsection{Análise dos Hantavírus associados às subfamílias de roedores}

\subsubsection{Arvicolinae}

Os Hantavírus associados a roedores subfamília Arvicolinae, contém até o momento 9 espécies de Hantavírus distribuídos em 18 países, predominando no continente europeu e asiático, e são divididos topologicamente em dois grupos, como mostra a Figura 11.

No grupo Myodes, o vírus mais frequente foi o Puumala, com amostras coletadas entre 1991 e 2010. Este subclado foi nomeado assim, pois as sequências deste vírus foram encontradas em roedores das espécies Myodes glareolus (Clethrionomys glareolus) e Myodes rufocanus (Clethrionomys rufocanus), ambos do gênero Myodes. A associação do vírus Puumala com estas espécies de roedores foi constatada na Rússia, Finlândia, Letônia, Suécia, Eslováquia, Alemanha, China e Japão. De todas as sequências completas disponíveis, 
somente uma sequência do vírus Puumala era de origem humana, de um paciente na Finlândia (NC005224). Além do vírus Puumala, o grupo Myodes incluiu outros vírus, também, identificados em roedores do gênero Myodes, na Rússia (vírus Ussuri), China (vírus Shenyang e Yuanjiang), Japão (vírus Hokkaido) e Coreia do Sul (vírus Muju).

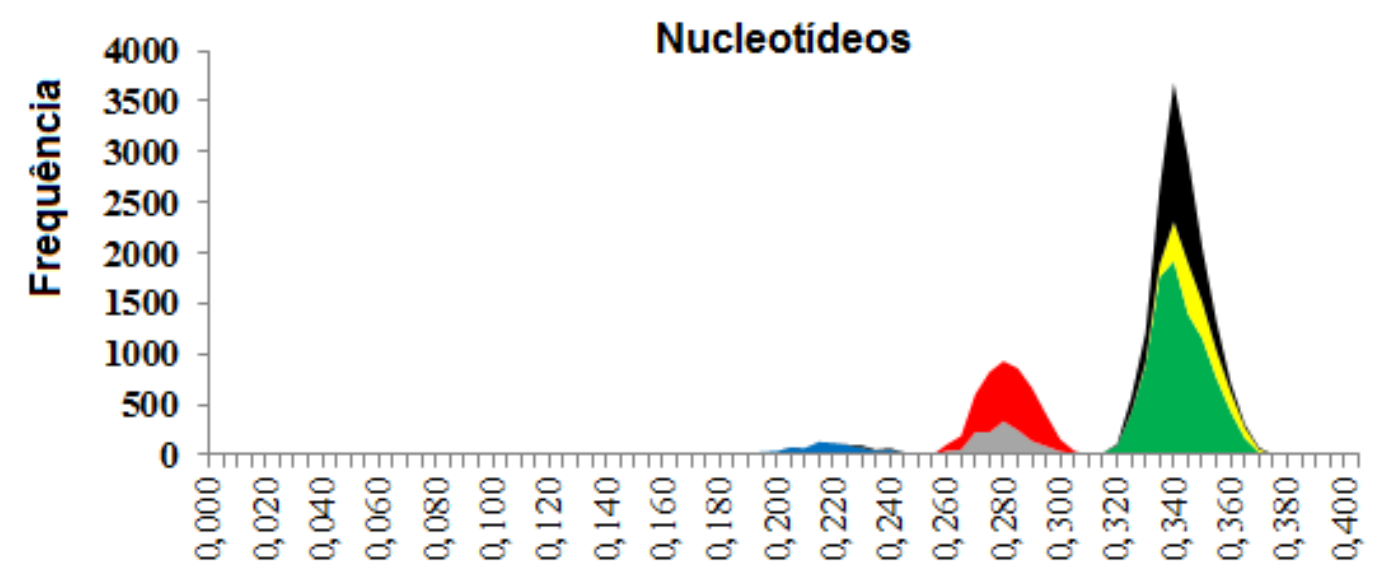

Aminoácidos

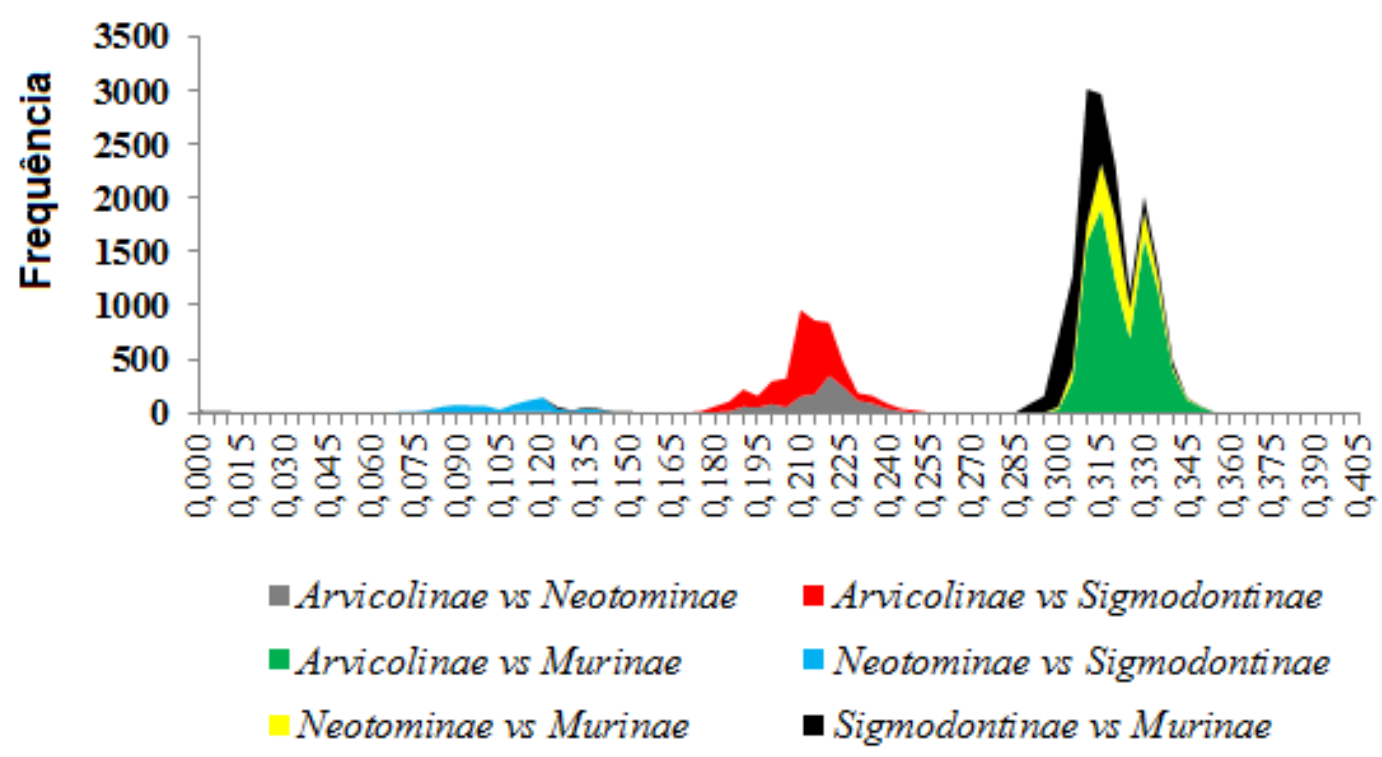

Figura 12. Frequência da divergência nucleotídica e aminoacídica entre Hantavírus associados a subfamílias de roedores reservatórios.

O grupo Microtus possui 3 espécies virais obtidas entre 1994 e 2003. O vírus Tula foi o mais frequente neste grupo, sendo identificado principalmente em roedores da espécie Microtus arvalis do leste e centro da Europa, em países como República Checa, Alemanha, Croácia, Sérvia e no Cazaquistão, situado no oeste da Ásia. No grupo Microtus, foram encontradas duas sequências de vírus Hantaan (AF063892; AF063897), que habitualmente são encontrados em roedores da subfamília Murinae. Entretanto estas amostras foram 
identificadas em roedores do mesmo gênero que os reservatórios do vírus Tula. Única exceção ao continente europeu ou asiático neste grupo foi o vírus Isla identificado no roedor Microtus californicus, em 1994, nos EUA (U31535; U31534).

Portanto os Hantavírus associados aos roedores da subfamilia Arvicolinae, são divididos filogeneticamente em vírus encontrados em roedores do gênero Myodes como o vírus Puumala e suas variações, e vírus que possuem como roedores reservatórios, espécies do gênero Microtus onde são encontrados principalmente o vírus Tula e o vírus Isla, conforme e apresentado na Figura 11.

\subsubsection{Neotominae}

Com base na árvore, os Hantavírus transmitidos por roedores da subfamília Neotominae são constituídos por 8 espécies virais, é com base na topologia da árvore podem ser divididos em dois grupos: Neotominae I e Neotominae II, como apresentado na Figura 11.

No grupo Neotominae I, agruparam-se vírus encontrados em roedores dos gêneros Peromyscus e Reithrodontomys. No gênero Peromyscus observam-se os vírus Carrizal (espécie Peromyscus megalopus) e Montano (espécie Peromyscus beatae), ambos mexicanos. Os vírus oriundos de amostras tissulares de roedores Reithrodontomys são o vírus Huitzilac (Reithrodontomys. megalotis) no México, e o vírus Rio Segundo (Reithrodontomys mexicanus) na região central da Costa Rica e o vírus El Moro Canyon (Reithrodontomys megalotis) no oeste dos EUA.

O Neotominae II inclui três espécies de Hantavírus encontrados em roedores do gênero Peromyscus: o vírus Sin Nombre e o Monongahela, ambos identificados na espécie Peromyscus maniculatus, além de um Hantavírus (NFG357, JN196140) encontrado em Peromyscus leucopus, na região de Great Smoky Mountain nos EUA. As únicas sequências oriundas de pacientes com SPCVH são as do vírus Sin Nombre, com as respectivas identificações: L25784 e NC 005216.

Os Hantavírus associados aos roedores da subfamilia Neotominae, na América Central e no Sul do EUA, tem como hospedeiros roedores do gênero Peromyscus e Reithrodontomys. Na América do Norte, o principal gênero responsável pela transmissão de Hantavírus são espécies de roedores do gênero Peromyscus.

\subsubsection{Sigmodontinae}

O grupo de Hantavírus que têm Sigmodontinae como reservatório apresentou a maior diversidade de espécies. Foi constituído por 17 espécies de Hantavírus oriundos de 6 países da 
América do Sul e Panamá obtidas dos tecidos de roedores de diversos gêneros, entre 1992 e 2008. No entanto não foi possível visualizar uma divisão de acordo com gênero de roedores hospedeiros, assim como ocorreu com os vírus associados aos roedores da subfamília Arvicolinae. Porém observamos, que os Hantavírus associados aos roedores da subfamília Sigmodontinae, são associados a duas tribos principais de roedores; tribo Oryzomyini, que são encontrados os vírus Rio Mamoré (Oligoryzomys microtis) no Peru e Bolívia, vírus Alto Paraguay (Holochilus chacarius) no Paraguai, vírus Choclo (Oligoryzomys fulvescens) no Panamá, os vírus paraguaios Neembucu (Oligoryzomys chacoensis) e Itapuã (Oligoryzomys nigripes), e os vírus argentinos Oran (Oligoryzomys longicaudatus), Lechiguanas (Oligoryzomys flavescens), Bermejo (Oligoryzomys chacoensis) e Andes (Oligoryzomys chacoensis), este ultimo encontrado também no Chile. E a tribo Akodontini encontra-se; os vírus Maciel (Necromys benefactus) e Pergamino (Akodon Azarae) na Argentina e o vírus Araraquara encontrado principalmente em Necromys lasiurus.

Conforme podemos observar na topologia da árvore, na Figura 11, assim como na divergência média e frequência Tabela 4 e Figura 12, os hantavírus associados à subfamília Neotominae e a Sigmodontinae, possuem uma divergência menor, quando comparado aos hantavírus associados a outras subfamîlias, como, Arvicolinae e Murinae. Está associação próxima, faz com que muitos autores considerem hantavírus associados à subfamília Neotominae, contidos em hantavírus associado aos Sigmodontinae, no entanto em nossas análises consideramos estas subfamílias separadamente, assim como ocorre na taxonomia dos roedores.

\subsubsection{Murinae}

O grupo de Hantavírus que possuem como roedores reservatórios da subfamília Murinae foram o com maior número de sequências encontradas. Foram analisados 10 espécies de Hantavírus, em amostras obtidas de 1986 a 2007 e oriundas de 11 países do continente europeu e asiático. Assim, com base na topologia da árvore, pudemos discriminar dois grupos, como mostra a Figura 11.

O grupo Rattus, apresentado na Figura 11, incluiu o vírus Seoul, oriundo dos tecidos de roedores das espécies Rattus norvegicus, Rattus rattus, Rattus flavipectus e em uma única amostra, de Mus norvegicus albus, além de amostras de casos humanos (AF488707; AF288294; GQ279395; GQ279394; GQ279391; GQ279390; GQ279389; GQ279384; GQ279381; GQ279380; GQ279379). As espécies de roedores dos quais detectaram-se estes Hantavírus eram principalmente da China, e também, duas sequências eram da Coreia do Sul 
(HQ611980; AY273791) e duas de Cingapura (GQ274945; GQ274944). Ainda, 2 vírus incluídos no mesmo ramo do vírus Seoul, foram o Jurong identificado em Rattus tanezumi de Cingapura e o vírus Thailand da Tailândia, encontrados em roedores da espécie Bandicota Indica e em um caso de doença humana.

O grupo Apodemus incluiu 3 espécies de Hantavírus. O ramo superior deste grupo foi formado predominantemente pelo vírus Dobrava, com sequências oriundas de países europeus, tais como, Alemanha, Rússia, Eslováquia, Eslovênia. Também, incluiu uma variação do Dobrava denominada vírus Saaremaa, identificada na Dinamarca em Apodemus agrarius e Apodemus flavicollis. No ramo inferior deste grupo, localizou-se o vírus Hantaan, protótipo do gênero Hantavírus, tendo como amostra mais antiga a de uma paciente com síndrome renal, de 1986. Vírus Hantaan foi identificado em roedores Apodemus agrarius e menos frequentemente em Rattus rattus, Apodemus peninsulae, Niviventer confucianus, Rattus nitidus e Rattus norvegicus. Outros Hantavírus como o Amur, encontrado na China e o Soochong, da Coreia do Sul, eram ambos oriundos de Apodemus peninsulae.

Portanto os Hantavírus associados aos roedores da subfamilia Murinae, podem ser divididos em vírus encontrados em roedores do gênero Rattus, tendo como principal representante o vírus Seoul. E Hantavírus que possuem como roedores reservatórios, principalmente espécies do gênero Apodemus onde é encontrado principalmente o vírus Dobrava e o vírus Hantaan, como e sugerido na Figura 11.

\subsubsection{Análise filogeográfica dos Hantavírus associados a roedores}

Para a reconstrução do ancestral comum e a análise filogeográfica, utilizamos 190 sequências da região codificadora da nucleoproteína de Hantavírus associados a roedores. Em nosso conjunto de dados inicial, as amostras provenientes da China foram super-representados $(\mathrm{n}=86,34 \%)$, quando comparados aos de outros países $(\mathrm{n} \leq 21)$. Para evitar potenciais vieses nas reconstruções filogeográficos devido ao número desigual de amostras de diferentes locais, criamos um subconjunto de "não-redundantes" representativos seqüências chinesas. Assim, sequências muito semelhantes (identidade $\geq 97 \%$ ) da China foram agrupados com o programa CD-HIT (LI, GODZIK, 2006) usando um servidor web on-line (HUANG et al. 2010) e apenas uma sequiência por grupo foi selecionado. As localizações geográficas das sequências são apresentado na Tabela 5. 
Tabela 5. Países, número e ano das sequências nucleotídicas do segmento $\mathrm{S}$ dos Hantavírus associados a roedores, utilizadas para a análise filogeográfica.

\begin{tabular}{|c|c|c|}
\hline Países & $N$ & Ano das Amostras \\
\hline Paraguai & 4 & $1995-2000$ \\
\hline Peru & 1 & 1996 \\
\hline Bolívia & 4 & $1992-2008$ \\
\hline Brasil & 15 & 2001-2006 \\
\hline Argentina & 11 & 1997-1999 \\
\hline Chile & 4 & 1997-1999 \\
\hline Panamá & 1 & 2000 \\
\hline Venezuela & 1 & 1994 \\
\hline México & 8 & 2006 \\
\hline EUA & 11 & $1985-2006$ \\
\hline Costa Rica & 1 & 1989 \\
\hline Coreia do Sul & 10 & 1997-2009 \\
\hline China & 25 & $1999-2007$ \\
\hline Rússia & 21 & $1993-2005$ \\
\hline Suécia & 16 & 2004-2005 \\
\hline Finlând ia & 3 & $1991-2000$ \\
\hline Letônia & 5 & $2000-2008$ \\
\hline Japão & 10 & $1995-2010$ \\
\hline Polônia & 2 & 1995 \\
\hline Servia & 1 & 1997 \\
\hline Croácia & 1 & 2000 \\
\hline Republica Checa & 1 & 1995 \\
\hline Alemanha & 15 & $1997-2008$ \\
\hline Cazaquistão & 1 & 1995 \\
\hline Eslováquia & 6 & 2001-2004 \\
\hline Tailând ia & 2 & 1998-2004 \\
\hline Singapura & 4 & 2006 \\
\hline Guine & 2 & 2004 \\
\hline Grécia & 3 & 1999 \\
\hline Dinamarca & 1 & 2000 \\
\hline TOTAL & 190 & 1985-2010 \\
\hline
\end{tabular}

Observamos na árvore 2 principais clados genéticos, o dos Hantavírus associados a roedores da familia Muridae (subfamília Murinae) e o dos associados à família Cricetidae (subfamilia Arvicolinae, Neotominae e Sigmodontinae). Por sua vez, estes clados principais se subdividiram em subclados ou grupos que foram denominados segundo as subfamílias de 
roedores-reservatório, associadas aos respectivos vírus e também às suas origens, como mostra a Figura 13.

Utilizando a taxa média de substituição nucleotídica para o segmento $\mathrm{S}$ dos Hantavírus em $6.8 \times 10^{-4}\left(2.5 \times 10^{-4}-1 \times 10^{-3}\right)$ substituições por sítio/ano. Supõe-se que o ancestral comum mais recente do gênero Hantavírus teria existido há 1917 anos (95\% HPD: 5541-922 anos atrás), como sugere a Figura 13. Porém, a dispersão dos Hantavírus pelo mundo teria ocorrido há no início do século XVI, com um aumento do número de espécies de Hantavírus, até os últimos 50 anos, onde o número de espécies teve uma ligeira queda, estabilizando-se em nas espécies atuais, como sugere a Figura 14.

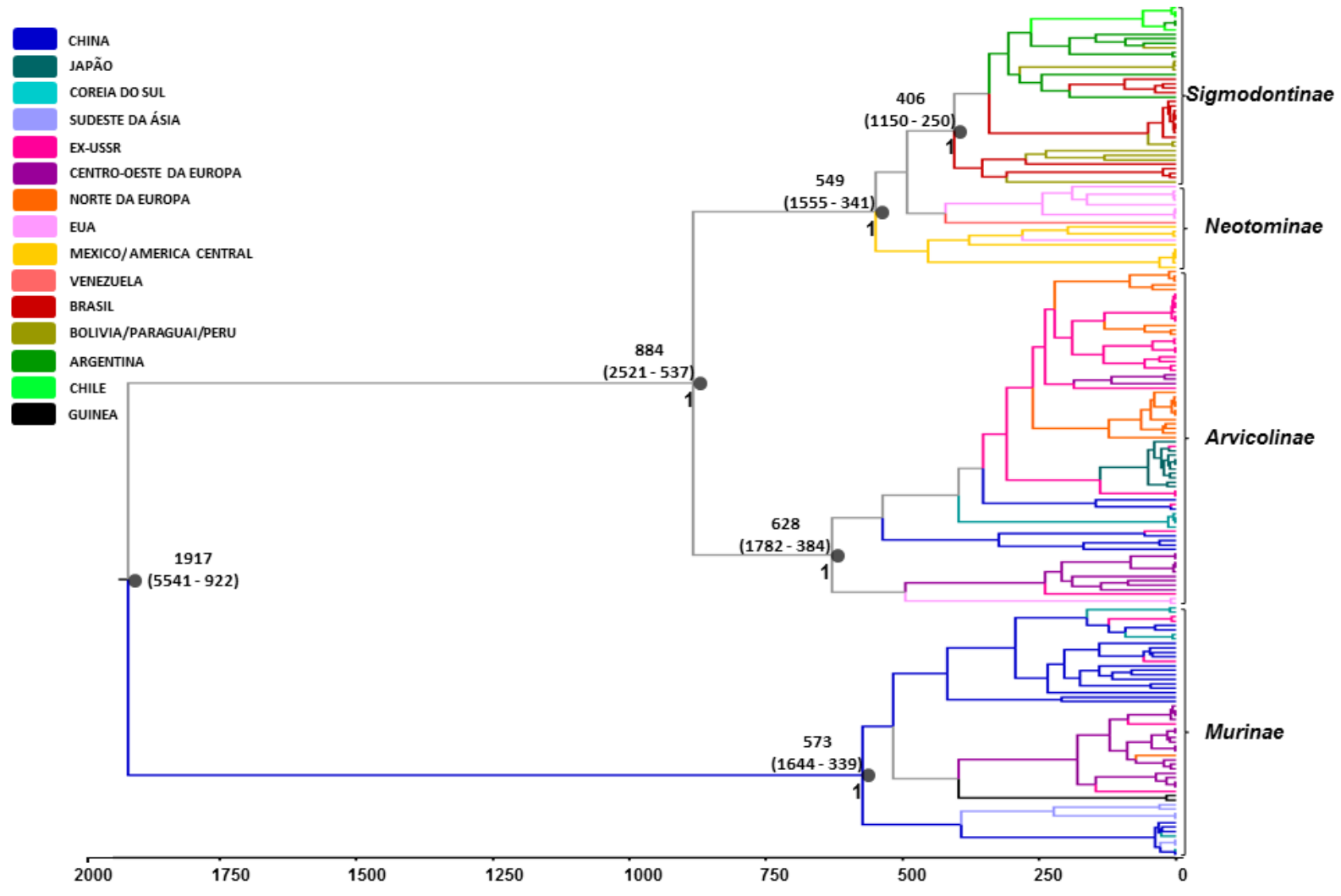

Figura 13: Árvore de 190 sequências do segmento S de Hantavírus associados a roedores, considerando a escala temporal de origem dos mesmos, segundo análise de Bayesian Maximum Clade Credibility. Os ramos da árvore foram coloridos segundo a localização geográfica do táxon. Ramificações internas foram coloridas pela mais provável localização do seu nó parental. A idade (com 95\% HPD entre parênteses) e as probabilidades posteriores são mostradas nos clados principais. Comprimentos de ramos na árvore correspondem à escala do tempo.

Além disso, estimamos o tempo em que se originou o ancestral comum mais recente (ACMR) dos Hantavírus associados às principais subfamílias de hospedeiros: para os Hantavírus associados a roedores Murinae foi há 573 anos (95\% HPD 1644-339 anos), para 
os associados a roedores Arvicolinae, foi há 628 anos (95\% HPD 1782-384 anos), para os associados a roedores Neotominae foi há 549 anos (95\% HPD 1555-341 anos) e para os Hantavírus associados a roedores Sigmodontinae foi há 406 anos (95\% HPD 1150-250 anos), como mostra a Figura 13. Também, determinou-se a provável localização geográfica do ancestral comum dos Hantavírus associados às subfamílias de roedores, como mostra a Figura 15.

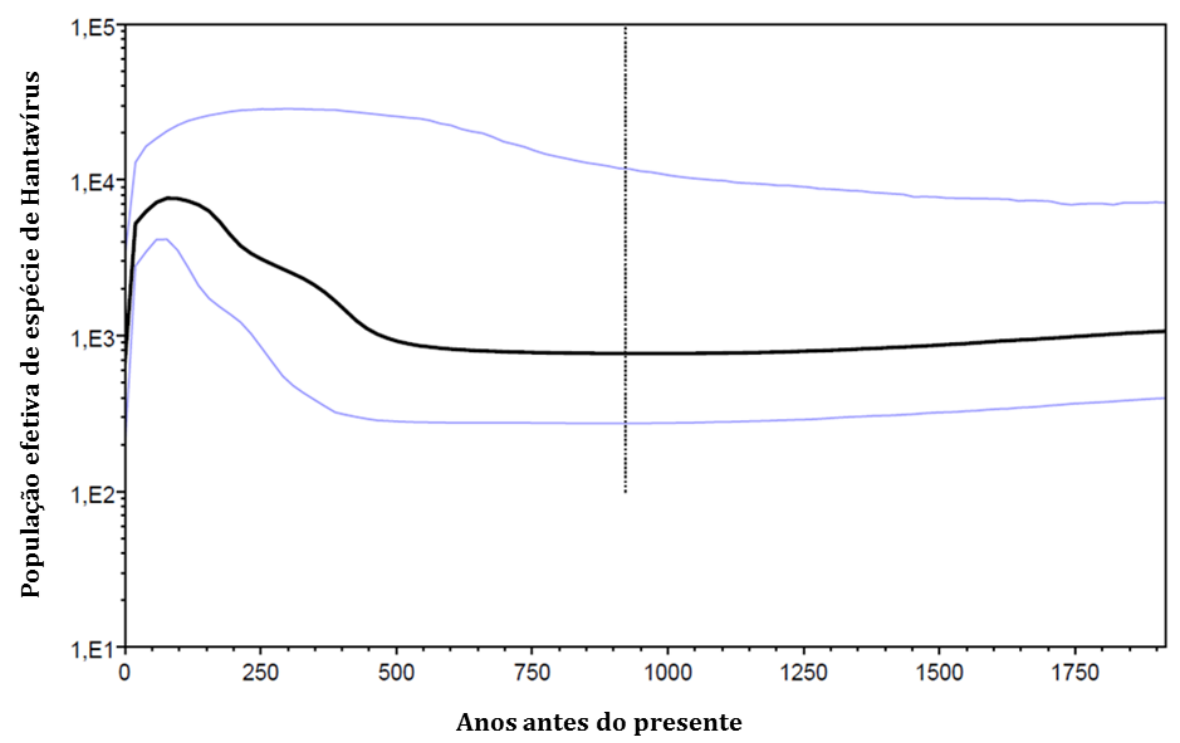

Figura 14: Dispersão dos Hantavírus pela linha do tempo utilizando o uma reconstrução Bayesian skyline, das sequências do segmento $\mathrm{S}$ dos Hantavírus associados a roedores. $\mathrm{O}$ eixo $\mathrm{X}$ é em unidades de anos antes de 2010, e no eixo Y é igual ao tamanho da população efetiva de espécie de vírus. A linha mais espessa é a estimativa mediana, e as linhas em azul mostram os limites de 95\% HPD. 
Murinae/Arvicolinae/Neotominae/Sigmodontinae
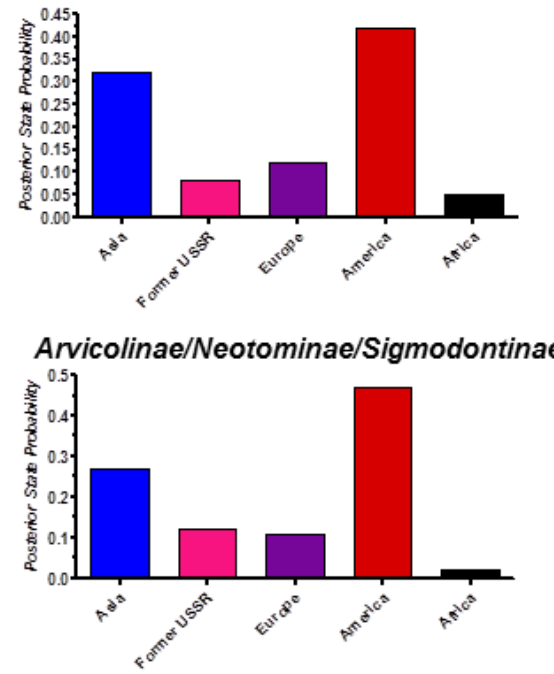

Neotominae/Sigmodontinae

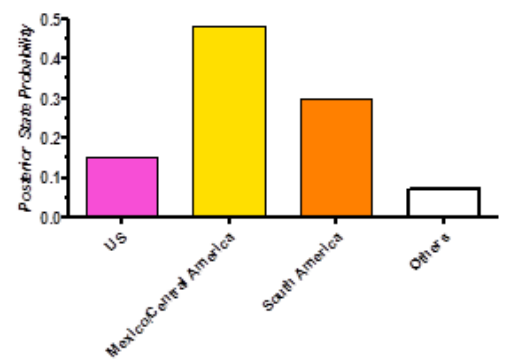

Murinae

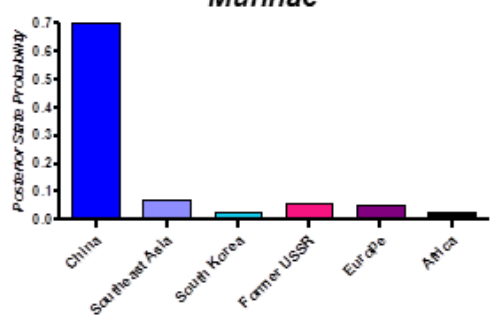

Arvicolinae

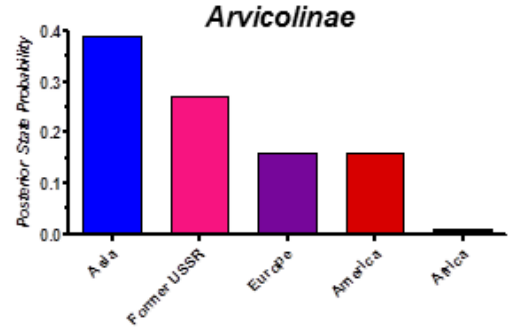

Sigmodontinae

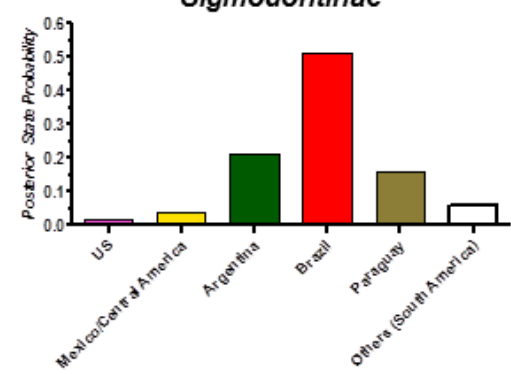

Figura 15: Probabilidades geográficas da origem de ancestrais comuns dos Hantavírus associados às principais subfamílias de roedores reservatórios.

\section{DISCUSSÃO}

\subsection{RT-PCR EM TEMPO REAL}

A reação em cadeia da polimerase (PCR) tem sido amplamente utilizada em todo o mundo no diagnóstico de infecções, incluindo aquelas de etiologia viral como é o caso dos Hantavírus (MACKAY, 2004; MACKAY, ARDEN, NITSCHE, 2002). Contudo, esta metodologia encontra-se em franca evolução e neste sentido, a PCR em tempo real possui algumas vantagens sobre a PCR convencional, tais como: exige menor tempo de execução, é executada com menor risco de contaminação, possui maior sensibilidade e possibilita quantificar o genoma viral (AITICHOU et al., 2005; JAKAB et al., 2007).

Nas últimas décadas, RT-PCR's quantitativas em tempo real foram desenvolvidas para a detecção genômica de alguns Hantavírus. Estas técnicas utilizam sistema TaqMan (AITICHOU et al., 2005; NASLUND et al., 2011; EVANDER et al., 2007; TROMBLEY et al., 2004; SAKSIDA et al., 2008). No presente estudo, desenvolvemos uma one-step RT-PCR em tempo real utilizando o sistema SYBR Green I. Com esta técnica, além da detecção, pôde- 
se quantificar o vírus Araraquara, um importante causador de SCPVH no Brasil, e provavelmente o mais letal vírus do gênero no mundo.

Dois fatores preponderaram na escolha do método SYBR Green I utilizada em nossa one-step RT-PCR em tempo real: eventuais alterações genômicas como mutações, deleções e/ou recombinação nestes vírus de RNA que, dependendo da localização, poderiam escapar a sondas TaqMan de alta especificidade produzindo resultados falso-negativos (PAPIN et al., 2004; DASH et al., 2012); além disso, o sistema SYBR Green I possui um menor custo quando comparado aos outros sistemas de RT-PCR em tempo real, como o TaqMan (AITICHOU et al, 2005; KRAMSKI et al, 2007).

Após escolher e produzir adequadamente o produto genômico transcrito, testamos variações dos reagentes para determinarmos a reação ideal em tempo real. Foram alterados diversos parâmetros, tais como volume da reação, temperatura e ciclo térmico da transcrição reversa, como apresentamos na Tabela 1. Tais parâmetros costumam ser variados em diferentes RT-PCR quantitativas em tempo real utilizadas em virologia (MACKAY, 2004; MACKAY, ARDEN, NITSCHE, 2002).

Um fator crítico no uso do sistema SYBR Green I, é a produção frequente de sinais falso-positivos, pela ligação inespecífica de fluoróforos a qualquer dupla fita, incluindo sequências inespecíficas e a dímeros de primers (ou primer-dimer), resultando na emissão de fluorescência inespecífica (BOWERS; DHAR et al., 2011). Para minimizar o efeito mencionado, foi utilizada a enzima DNase I, que degrada todo o DNA presente nas amostras após a extração do RNA viral. Ainda, os volumes dos primers foram alterados de $1 \mu \mathrm{l}$ na concentração de $10 \mathrm{mM}$, para um volume ideal de $0,35 \mu \mathrm{l}$ em cada reação na mesma concentração, pois observamos ao utilizarmos $1 \mu$, ocorriam ligações inespecíficas, provavelmente decorrência de primer-dimer, resultando em $\mathrm{T}_{\mathrm{M}}$ variada.

A one-step RT-PCR em tempo real SYBR Green I para Hantavírus mostrou-se específica com base na curva de dissociação do teste, que mostra a amplificação das amostras positivas para Hantavírus à $\mathrm{T}_{\mathrm{M}}$ de $80,5^{\circ} \mathrm{C} \pm 0,35^{\circ} \mathrm{C}$, como mostra a Figura 10. A $\mathrm{T}_{\mathrm{M}}$ permite detectar e desconsiderar resultados de primer-dimers ou amplificação de produtos inespecíficos (AITICHOU et al., 2005; PRYOR, WITTWER, 2006). Utilizando o mesmo sistema e equipamento, Araújo e colaboradores (2012), relataram uma temperatura de $82,1^{\circ} \mathrm{C}$ na detecção de Hantavírus em roedores na região do município de Biritiba Mirim, no estado de São Paulo. Recentemente uma RT-PCR em tempo real, divulgada para detectar e quantificar diferentes Hantavírus, tais como Andes, Dobrava, Hantaan, Puumala, Seoul, Sin Nombre e Tula, mostrou $\mathrm{T}_{\mathrm{M}}$ variando entre $77,5^{\circ} \mathrm{C}$ e $81^{\circ} \mathrm{C}$. Em ambos os trabalhos, as 
temperaturas mostraram-se próximas à da $\mathrm{T}_{\mathrm{M}}$ observada em nosso estudo (MOHAMED et al., 2013).

$\mathrm{O}$ uso de produtos clonados de transcrição in vitro é amplamente utilizado nas técnicas de RT-PCR em tempo real, como controle positivo específico para o genoma e para estimar a quantidade de cópias de RNA. O uso de tais produtos como controle no teste exclui a necessidade de isolado viral que, neste caso, oferece problemas de biossegurança e reduz possíveis contaminantes (BOWERS; DHAR et al, 2011; MACKAY, ARDEN, NITSCHE, 2002). Para utilizarmos a one-step RT-PCR em tempo real SYBR Green I como método quantitativo de Hantavírus, construímos uma curva-padrão de cinco pontos utilizando as diluições decimais do transcrito clonado do RNA viral entre $10^{8}$ a $10^{3}$ cópias de RNA por mL (Figura 9) e fomos capazes de quantificar o vírus em amostras clínicas plotando os resultados na curva-padrão. Outros autores desenvolveram RT-PCR em tempo real para quantificação de Hantavírus utilizando o mesmo sistema de curva-padrão com diluições decimais de produtos de transcrição (MOHAMED et al., 2013; EVANDER et al., 2007).

A one-step RT-PCR em tempo real SYBR Green I para Hantavírus mostrou-se específica porque, quando submetemos diferentes vírus causadores de doença humana, tais como, Coxsackie B5, Influenza A, Vírus Respiratório Sincicial Humano A, Parainfluenza-2, Metapneumovírus, Rinovírus-39 e Oropouche (que pertence a outro gênero na família Bunyaviridae) não obtivemos amplificação do RNA destes vírus na $\mathrm{T}_{\mathrm{M}}$ específica.

Por outro lado, o método mostrou-se, provavelmente, gênero-específico, pelo menos para Hantavírus sul-americanos, porque amplificamos adequadamente o Hantavírus Rio Mamoré oriundo de cultivo celular. Esta amplificação deveu-se aos primers utilizados no teste, que foram intencionalmente desenhados por Moreli e colaboradores (2004), para amplificar uma região conservada no genoma de Hantavírus sul-americanos. Portanto, outros Hantavírus poderiam ser amplificados por esta técnica, além dos vírus Araraquara e Rio Mamoré. Com estes primers, Moreli e colaboradores (2004) relatam ser possível amplificação genômica dos vírus Andes e Castelo dos Sonhos, além do Rio Mamoré e do Araraquara, porque sequências de tais vírus possuem uma similaridade de aproximadamente $88,9 \%$ na região alvo de anelamento dos primers.

A sensibilidade da one-step RT-PCR em tempo real SYBR Green I para o vírus Araraquara e Rio Mamoré, mostrou-se inferior à de outra RT-PCR em tempo real, descrita para o vírus Puumala usando o sistema Taqman, que têm um limite de detecção de até uma cópia por reação (SAKSIDA et al., 2008). No entanto nosso método pode detectar até 10 cópias por $\mathrm{mL}$, o que é bastante satisfatório, pois estudos com amostras clínicas de pacientes 
acometidos com vírus Puumala, relatam que a viremia destes pacientes varia entre $10^{2}$ a $10^{8}$ cópias de RNA viral por $\mathrm{ml}$ de soro. Considerando está carga viral para Hantavírus americanos seria possível detectar facilmente o vírus em pacientes com SPCVH utilizando nossa metodologia (EVANDER et al., 2007).

A one-step RT-PCR em tempo real SYBR Green I mostrou-se reprodutível e pôde ser validada testando-se 20 amostras séricas de pacientes com sorologia positiva para Hantavírus. A técnica foi capaz de detectar genoma viral em todas as amostras positivas pela RT-PCR convencional e ainda, detectou genoma viral em duas amostras negativas pela variante convencional. Desta forma, observamos que pacientes com SPCVH e carga viral baixa poderiam não estar sendo diagnosticados com a técnica de detecção genômica convencional. Embora não conheçamos o estágio clínico em que foram colhidas as amostras em nosso estudo, supomos que estes pacientes estariam em declínio da carga viral.

Ainda, nossa one-step RT-PCR em tempo real SYBR Green I para Hantavírus, descontando-se o tempo para extração de ácidos nucléicos da amostra clínica, é realizada em 2 horas e, portanto, mais rapidamente que a RT-PCR convencional que toma cerca de 5 horas, incluindo ciclos de transcrição reversa com tempo médio de 2 horas e mais 3 horas para a os ciclos de amplificação. O curto tempo de execução da técnica em tempo real deveu-se à redução no número de etapas do teste. Além disso, esta realizada em sistema fechado, em única etapa e utilizando transcrito viral, diminuem os riscos de contaminação se comparada à RT-PCR convencional ou em tempo real com etapas distintas de transcrição e amplificação do genoma viral (MACKAY et al. 2002).

Finalizamos esta parte da discussão ressaltando que desenvolvemos uma one-step RT-PCR em tempo real para Hantavírus específica, sensível e que deverá ser muito útil para o diagnóstico de pacientes com SPCVH, inclusive, permitindo correlacionar gravidade e a evolução com a carga viral. Também, esta técnica deverá ser usada em outros estudos com Hantavírus relacionados a tratamentos da SPCVH, fisiopatologia da doença, roedoresreservatório e desenvolvimento de vacinas.

\subsection{ESTUDO EVOLUTIVO DOS HANTAVÍRUS}

A história evolutiva dos Bunyaviridae do gênero Hantavírus inclui um processo de evolução em seus hospedeiros naturais. Durante muito tempo acreditou-se na convergência evolutiva dos Hantavírus com seus hospedeiros, está hipótese surgiu baseada na observação de que os principais grupos dos Hantavírus estavam associados e agrupavam-se com determinadas subfamilias de roedores, como mostra a Figura 11 (HUGHES, FRIEDMAN, 
2000; PLYUSNIN, MORZUNOV 2001; NEMIROV et al, 2004). Entretanto, um estudo recente mostrou que a hipótese dos Hantavírus terem co-evoluido com seus roedoresreservatório é pouco provável, pois as taxas evolutivas e ACMR estimados para o gênero Hantavírus eram incompatíveis com a história evolutiva, muito mais lenta, dos roedores, mostrando que a congruência filogenética de patógeno-hospedeiro, neste caso, não indicava uma convergência evolutiva (RAMSDEN, HOLMES, CHARLESTON, 2009). Deste modo, em nosso estudo, desconsideramos a convergência evolutiva entre Hantavírus e roedoresreservatório, embora tenhamos observado que linhagens ancestrais destes vírus, durante o processo evolutivo, teriam se adaptado a determinadas subfamilias de roedores, como Arvicolinae, Neotominae e Sigmodontiae (família Cricetidae) e Murinae (família Muridae), como mostra Figura 11.

Desconsiderando a hipótese de congruência evolutiva, optamos por estimar o ACMR dos Hantavírus associados às principais famílias e subfamílias de roedores, utilizando uma taxa média de substituição descrita para o segmento $S$ do genoma viral, que mostrou-se condizente com as taxas evolutivas de vírus de rápida evolução, como os de RNA (RAMSDEN et al 2008, RAMSDEN, HOLMES, CHARLESTON, 2009, HOLMES, 2011). Em nossa estimativa, o ACMR dos Hantavírus associados a roedores mostrou-se de 1917 anos atrás (Figura 13), no entanto não e possível determinar a localização geográfica de sua origem (Figura 15). Nossa data estimada é maior que a ACMR sugerida por Ramsden e colaboradores em 2009, de aproximadamente 900 anos, no entanto, estes autores fizeram uma ressalva sobre a interpretação de seus resultados, devido aos dados limitados utilizados (RAMSDEN, HOLMES, CHARLESTON, 2009).

Utilizando uma reconstrução bayesiana com o modelo Skyline, observamos que a dispersão inicial dos Hantavírus ocorreu aproximadamente há 500 anos. Portanto, da origem ao momento da dispersão global, teria ocorrido um longo período de latência.

Nossa análise filogenética mostrou que os Hantavírus associados à subfamilia Murinae originaram-se, provavelmente, na China, há 573 anos, como sugere a Figura 16. Este ancestral teria sido o precursor do vírus Hantaan, protótipo do gênero Hantavírus e agente etiológico da FHSR, oriunda do roedor Apodemus agrarius (Lee et al., 1981). A partir da China, onde haviam roedores dos gêneros Rattus e Apodemus, teria ocorrido à disseminação dos Hantavírus associados à subfamilia Murinae. Desta forma, os Hantavírus de Murinae, chegaram ao leste e centro da Europa, onde teriam se adaptado aos roedores do gênero Apodemus, o que teria resultado no vírus Dobrava, um importante causador de FHSR na Alemanha, Rússia, Sérvia e Grécia, como mostra a Figura 16 (PAPA, 2012). 
Em um processo semelhante, roedores infectados com Hantavírus teriam migrado da China para o leste e sudeste da Ásia e estes vírus teriam se adaptado aos roedores do gênero Rattus. A dispersão para o leste, especificamente na Coréia do Sul, teria resultado no vírus Seoul, o provável agente etiológico do surto de FHSR ocorrido durante a guerra de 1950 a 1953, acometendo mais de 3.000 soldados (JONSSON, FIGUEIREDO, VAPALAHTI, 2010). A disseminação de Hantavirus ancestrais ao sudeste asiático teria originado os vírus Thailand e Jurong, encontrados respectivamente na Tailândia e Cingapura, apresentada na Figura 16 (HUGOT et al., 2006, JOHANSSON et al., 2010).

Os Hantavírus, no processo de disseminação da Ásia rumo oeste, provavelmente via Oriente Médio, foram introduzidos na África, embora ali tenha sido identificada apenas uma espécie, na Guiné, como mostra a Figura 16 (KLEMPA et al., 2012). O ancestral comum dos hantavírus associados à família Cricetidae teria existido há 884 anos no Velho Mundo. Uma linhagem ancestral deste vírus teria infectado roedores da subfamilia Arvicolinae, há aproximadamente 628 anos. Tal fato teria ocorrido na Ásia, como sugere Figura 15.

Os Hantavírus associados a roedores Arvicolinae teriam se disseminado pela Ásia. As linhagens ancestrais associaram-se aos roedores do gênero Myodes (anteriormente conhecido como Clethrionomys), migrando para a Sibéria e toda a China de onde teriam se originado os vírus Shenyang e Yuanjiang (JONSSON, FIGUEIREDO, VAPALAHTI, 2010; ZOU et al., 2008). Este processo de dispersão teria seguido até o Japão, onde teria se originado o vírus Hokkaido, como mostra a Figura 16 (KARIWA et al., 1999).

A introdução na Europa dos Hantavírus associados a roedores da subfamília Arvicolinae teria ocorrido pela Sibéria atingindo a Escandinávia. Desta forma teria se originado o vírus Puumala, causador de surtos de nefropatia nesta região, uma forma mais branda de FHSR, descrita inicialmente na década de 1930 (JONSSON, FIGUEIREDO, VAPALAHTI, 2010). Os Hantavírus de Arvicolinae, também, teriam sido introduzidos da Ásia para o leste e o centro da Europa via Cazaquistão, em roedores do gênero Microtus, atingindo Polónia, República Checa Alemanha, Sérvia e teria originado o vírus Tula, conhecido como pouco ou não patogênico para seres humanos (Figura 16) (SCHLEGE et al., 2012).

Os Hantavírus podem ter sido introduzidos nas Américas na mesma ocasião em que teria ocorrido a dispersão mundial destes vírus ligados a roedores, há aproximadamente 549 anos. A introdução teria ocorrido pela América Central ou México e parece coincidir com o período da descoberta da América e chegada dos navegadores europeus a estas regiões. Supomos que esta introdução poderia ter ocorrido com roedores-reservatório Murinae 
embarcados nos navios oriundos da Europa ou Ásia. Entretanto, nosso estudo mostra que os Hantavírus americanos seriam próximos filogeneticamente dos vírus associados à Arvicolinae e como estes roedores não costumam embarcar em navios, não encontramos maneira lógica que explique esta introdução.

No continente americano, os Hantavírus adaptaram-se aos roedores da subfamília Neotominae, espalhando-se pelas Américas Central e do Norte, originando os vírus Carrizal e Huitzilac no México e o Rio Segundo na Costa Rica (Figura 13) (MUSSER, CARLETON, 2005; KARIWA et al., 2012). A migração rumo norte teria atingido os Estados Unidos onde teria originado o vírus Sin Nombre, o primeiro Hantavírus descrito como causador de SPCVH, fato ocorrido na região de Four Corners, em 1993 (Figura 16) (JONSSON, FIGUEIREDO, VAPALAHTI, 2010). Os Hantavírus da América Central e do Norte, teriam se adaptado aos roedores do gênero Peromyscus e Reithrodontomys. Exceções são os vírus Vista Isla e Prospect Hill, que foram isolados em roedores das espécies Microtus californicus e Microtus pennsylvanicus, ambos da subfamília Arvicolinae. Estes vírus são filogeneticamente muito próximos dos Hantavírus europeus, como o Puumala, que também é associado aos roedores do gênero Microtus (subfamília Arvicolinae) (SONG et al., 1995). Portanto, nosso estudo sugere a introdução dos Hantavírus do Velho Mundo, há cinco séculos, na América Central ou México. Entretanto, não é possível determinar como isto teria ocorrido, especialmente tratando-se de vírus ancestrais associados à Arvicolinae.

Também, oriundos da América Central, os Hantavírus teriam chegado à América do Sul há aproximadamente 406 anos onde adaptaram-se aos roedores da subfamília Sigmodontinae, das tribos Oryzomyini e Akodontini, as mais diversificadas e abundantes do continente sul-americano (Figura 13) (PARADA et al., 2013). Observamos neste ponto que a disseminação dos Hantavírus ancestrais associados à Sigmodontinae teria ocorrido a partir do Brasil, onde teriam originado os vírus Juquitiba, o primeiro Hantavírus identificado no Brasil e o vírus Araraquara, o Hantavírus mais virulento do mundo (FIGUEIREDO et al., 2009A). Entretanto, não entendemos como o Hantavírus ancestral, oriundo da América Central, teria chegado ao Brasil. Do Brasil, a disseminação dos Hantavírus ancestrais associados à Sigmodontinae teria ocorrido rumo oeste e teria originado os vírus Rio Mamoré e Laguna Negra na Bolívia, Peru e norte do Paraguai (JONSSON, FIGUEIREDO, VAPALAHTI, 2010). Mais ao Sul teria resultado no vírus Andes, o primeiro Hantavírus identificado na América do Sul, em 1993 e também, o principal agente etiológico da SCVPH na Argentina e Chile (Figura 16) (PADULA et al., 2004). Observamos ainda, outra possível rota de entrada 
dos Hantavírus na América do Sul, pela Venezuela, com base na similaridade filogenética entre o vírus venezuelano Caño Delgadito com Hantavírus de Neotominae (Figuras 13 e 16).

Os Hantavírus teriam evoluído adaptando-se a subfamílias de roedores e posteriormente, a alguns gêneros ou tribos nestas subfamílias, sugerindo o paradigma "um roedor - um Hantavírus". No entanto, trata-se de uma ideia muito simplificada e que não explica a real dinâmica dos Hantavírus com seus hospedeiros. Observa-se cada vez mais o "pulo da espécie-reservatório" (spillover), ou seja, a transmissão viral horizontal para outras espécies de roedores (PLYUSNIN, MORZUNOV 2001). Em nossas análises, observamos o spillover como um fenômeno comum como relatado para: o vírus Puumala que está associado a roedores da espécie Myodes glareolus, mas também pode ser encontrado em Myodes rufocanus, o vírus Seoul que possui como reservatórios os Rattus rattus e Rattus norvegicus: o vírus Andes, que possui como reservatório o Oligoryzomys longicaudatus, mas que tem suas variações, vírus Bermejo, Lechiguanas, Maciel, Oran e Pergamino associadas a outras espécies de Oligoryzomys, além do vírus Araraquara que tem como roedor-reservatório o Necromys lasiurus, porém também foi encontrado em Calomys tender (Apêndice A). De fato, acredita-se que a transmissão viral entre espécies poderia contribuir para a diversidade genética e a distribuição global dos Hantavírus (LIN et al., 2012; GUO et al., 2013). No entanto, nossas análises sugerem que a transmissão entre distintos gêneros de roedores, parece ser fenômeno pouco comum a espécies adaptadas a seus hospedeiros.

Ao final, observa-se uma diminuição do número de espécies virais nos últimos 50 anos, como mostrado na Figura 14. Este fato provavelmente é resultado da extinção de linhagens de vírus que não teriam se adaptado adequadamente ao longo do período evolutivo.

Em suma, nossos resultados permitem supor que os Hantavírus teriam aproximadamente 1917 anos e sua origem geográfica não e possível ser determinada. Após um longo período de latência, há 500 anos, os Hantavírus teriam se dispersado pelo mundo inclusive chegando ao Continente Americano e ao Brasil de onde estes vírus, associados à Sigmodontinae, teriam originado os vírus Juquitiba, Araraquara e migrado rumo oeste rumo à Argentina, Paraguai, Bolívia, Peru e Chile originando os vírus Andes, Rio Mamoré e Laguna Negra. O período de disseminação dos Hantavírus é compatível com o grande movimento humano entre continentes a partir do século XV e também, é o período em que surge a agricultura moderna, contribuir para $o$ aumento de alimentos aos animais com comportamentos sinantrópicos e comensais, como os roedores, deste modo contribuindo para a dispersão dos Hantavírus, com apresentado na Figura 16. 
Este trabalho contribui de forma relevante para o diagnóstico das infecções por Hantavírus com a one-step RT-PCR em tempo real SYBR Green I que foi desenvolvida e também, contribui para o entendimento da filogenia, evolução e história destes vírus emergentes e causadores de graves doenças, oferecendo subsídios ao entendimento sobre como teria ocorrido o espalhamento dos Hantavírus pelo mundo, incluindo as Américas e o Brasil. 


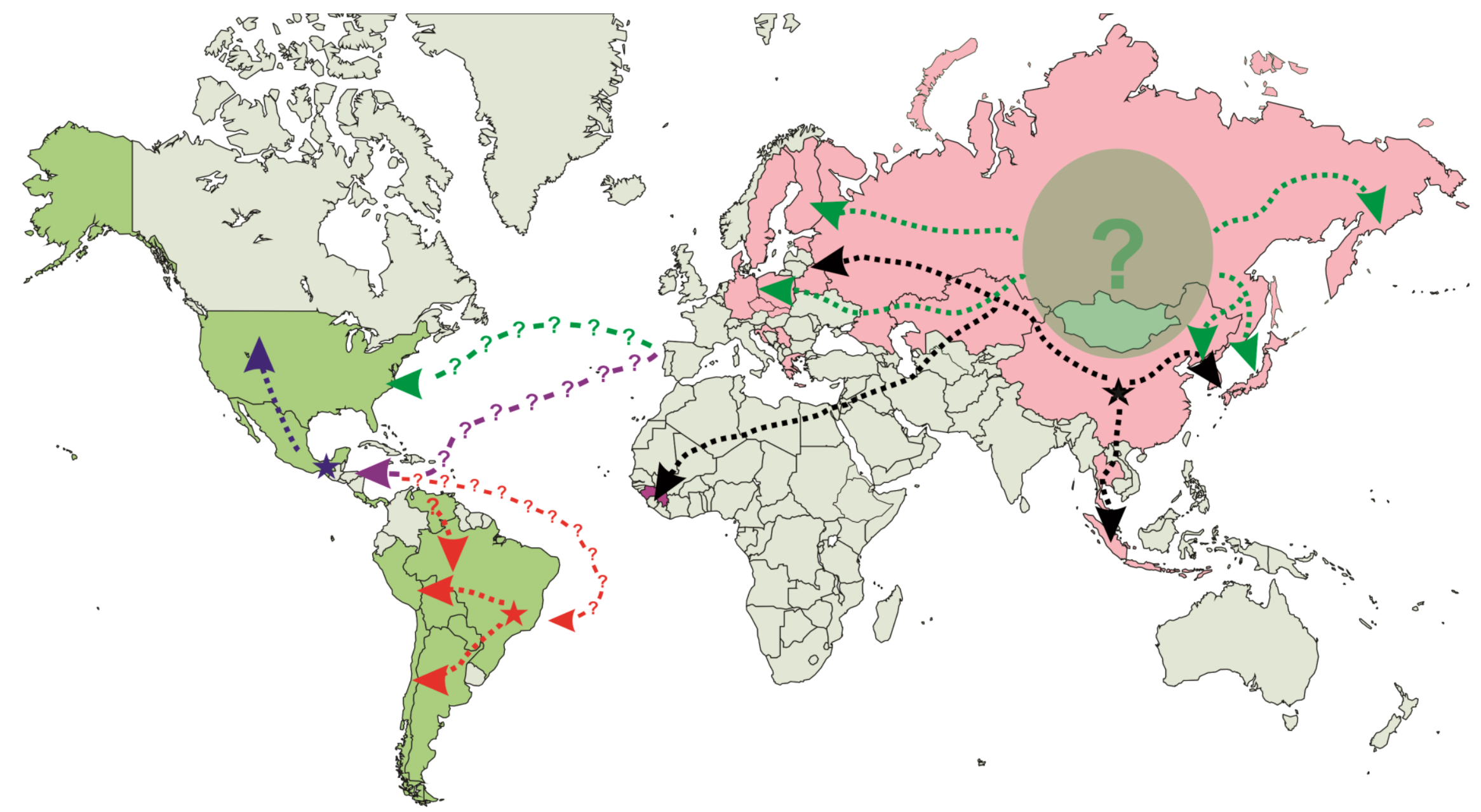

Dispersão de Hantavírus em Murinae Dispersão de Hantavírus em Arvicolinae

Dispersão de Hantavírus em Neotominae Dispersão de Hantavírus em Sigmodontinae Introdução dos Hantavírus nas Américas

\section{$\star$ Origem dos Hantavírus em Murinae}

$\star$ Origem dos Hantavírus em Neotominae

$\star$ Origem dos Hantavírus em Sigmodontinae

? Possível origem dos Hantavírus em Arvicolinae ?-?-? Rotas incertas

Figura 16: Prováveis rotas de dispersão dos Hantavírus associados a roedores pelo mundo. 


\section{CONCLUSÕES}

- Desenvolvemos uma one-step RT-PCR em tempo real SYBR Green I para Hantavírus Araraquara que mostrou-se específica e capaz de detectar até 10 cópias por mL de RNA viral na amostra em teste.

- O estudo computacional evolutivo dos Hantavírus com base no segmento $\mathrm{S}$ do genoma viral de 190 amostras analisadas por método bayesiano, permitiu estimar que os Hantavírus teriam aproximadamente 1917 anos e seriam originários da Ásia.

- A filogeografia, também, permitiu supor que há 500 anos os Hantavírus teriam se dispersado pelo mundo inclusive chegando ao continente americano e ao Brasil de onde associaram a aos Sigmodontinae, e teriam originado os vírus Juquitiba, Araraquara e dispersaram para a Argentina, Paraguai, Bolívia, Peru e Chile. 


\section{REFERÊNCIAS BIBLIOGRÁFICAS}

AITICHOU, M.; SALEH, S.S.; MCELROY, A.K.; SCHMALJOHN, C.; IBRAHIM, M.S. Identification of Dobrava, Hantaan, Seoul, and Puumala viruses by one-step real-time RTPCR. Journal Virological Methods. v.124, p.21-26, 2005.

ARAUJO, J.; THOMAZELLI, L.M.; HENRIQUES, D.A.; LAUTENSCHALAGER, D.; OMETTO, T.; DUTRA, L.M.; AIRES, C.C.; FAVORITO, S.; DURIGON, E.L. Detection of hantavirus in bats from remaining rain forest in Sao Paulo, Brazil. BMC Research Notes. v.21, n.5, p.690, 2012.

BONVICINO, C.R.; OLIVEIRA J.A.; D'ANDREA, P.S. Guia dos Roedores do Brasil, com chaves para gêneros baseadas em caracteres externos. Centro Pan - Americano de Febre Aftosa, Rio de Janeiro. 2008.

BORGES, A.A.; CAMPOS, G.M.; MORELI, M.L.; SOUZA, R.L.; AQUINO, V.H.; SAGGIORO, F.P.; FIGUEIREDO, L.T.M. Hantavirus cardiopulmonary syndrome: immune response and pathogenesis. Microbes Infectious. v.8, n.8, p.2324-2330, 2006.

BORGES, A.A.; DONADI, E.A.; CAMPOS, G.M.; MORELI, M.L.; SOUZA, R.L.M.; SAGGIORO, F.P.; FIGUEIREDO, G.G.; BADRA, S.J.; DEGHAIDE, N.H.S.; FIGUEIREDO, L.T.M. Association of $-308 \mathrm{G} / \mathrm{A}$ polymorphism of Tumor Necrosis Factorgene promoter with the susceptibility to development of Hantavirus Cardiopulmonary Syndrome in Ribeirão Preto region, Brazil. Archives of Virology. v. 155, p. 971-975, 2010.

BOWERS, R.M.; DHAR. A.K. Effect of template on generating a standard curve for absolute quantification of an RNA virus by real-time reverse transcriptase polymerase chain reaction. Molecular Cell Probes. v.25, n.1, p.60-64, 2011.

CHAPARRO, J.; VEGA, J.; TERRY, W.; VERA, J.L.; BARRA, B.; MEYER, R.; PETERS, C.J.; KHAN, A.S.; KSIAZEK, T.G. Assessment of person-to-person transmission of Hantavirus pulmonary syndrome in a Chilean hospital setting. Journal Hospital Infectious. v.40, n.4, p.281-285, 1998.

DELFRARO, A.; TOMÉ, L.; D'ElÍA, G.; ClARA, M.; ACHÁVAL, F.; RUSSI, J.C.; RODONZ, J.R. Juquitiba-like Hantavirus from 2 nonrelated rodent species, Uruguay. . Emerging Infectious Diseases. v.14, n.9, p.1447-1451, 2008.

DOBLY, A,; COCHEZ, C.; GOOSSENS, E.; DE BOSSCHERE, H.; HANSEN, P.; ROELS, S.; HEYMAN, P. Sero-epidemiological study of the presence of hantaviruses in domestic dogs and cats from Belgium. Research Veterinary Science. v.92, n.2, p.221-224, 2012.

DRUMMOND, A.J.; SUCHARD, M.A.; XIE, D.; RAMBAUT, A. Bayesian phylogenetics with BEAUti and the BEAST 1.7. Molecular Biology and Evolution. 2012

EASTERBROOK, J.D.; KLEIN, S.L. Immunological Mechanisms Mediating Hantavirus Persistence in Rodent Reservoirs. PLoS Pathogens. v.4, n.11 e1000172, 2008.

ELLIOTT, R.M. Bunyaviruses and climate change. Clinical Microbiology Infectious. v.15, n.6, p.510-517, 2009. 
EVANDER, M.; ERIKSSON, I.; PETTERSSON, L.; JUTO, P.; AHLM, C.; OLSSON, G.E.; BUCHT, G.; ALLARD, A. Puumala Hantavirus Viremia Diagnosed by Real-Time Reverse Transcriptase PCR Using Samples from Patients with Hemorrhagic Fever and Renal Syndrome. Journal Clinical Microbiology. v.45, p.2491-2497, 2007.

FIGUEIREDO, G.G.; MARTINS, A.M.; BISORDI, I.; NAGASSE-SUGAHARA, T.K.; SUZUKI, A.; PEREIRA, L.E.; SOUZA, R.P.; SOUZA, L.T.M.; BRACONI, C.T.; HARSI, C. M.; ZANOTTO, P.M., VGDN Consortium. Distinct Hantaviruses causing Pulmonary Syndrome in Central Plateau, Southeastern and Southern Brazil. Emerging Infectious Diseases.v. 15, n.4, p.561-567, 2009A.

FIGUEIREDO, L.T.M. Viral hemorrhagic fevers in Brazil. Revista da Sociedade Brasileira de Medicina Tropical. v.39, n.2, p.203-210, 2006.

FIGUEIREDO, L.T.M.; MORELI, M.L.; BORGES, A.A.; FIGUEIREDO, G.G.; SOUZA, R.L. M.; AQUINO, V.H. Expression of a Hantavirus N protein and its efficacy as antigen in immune assays. Brazilian Journal of Medical and Biological Reserarch. v.41, p.596-599, 2008.

FIGUEIREDO, L.T.M.; MORELI, M.L.; BORGES, A.A.; FIGUEIREDO, G.G.; BADRA, S.J.; BISORDI, I.; SUZUKI, A.; CAPRIA, S.; PADULA, P. Evaluation of a solid-phase enzyme immunoassay based on Araraquara Hantavirus recombinant nucleoprotein. American Journal of Tropical Medicine and Hygiene. v. 81, p. 273-276, $2009 \mathrm{~B}$.

GAVRILOVSKAYA, I.N.; SHEPLEY, M.; SHAW, R.; GINSBERG, M.H.; MACKOW, E.R. beta3 Integrins mediate the cellular entry of Hantaviruses that cause respiratory failure. Proceedings of the National Academy of Sciences. v.95, n.12, p.7074-7079, 1998.

GUU, T.S.; ZHENG, W.; TAO, Y.J. Bunyavirus: structure and replication. Advances Experimental Medical Biology. v.726, p.245-66, 2012.

GUO, W.P.; LIN, X.D.; WANG, W.; TIAN, J.H.; CONG, M.L.; ZHANG, H.L.; WANG, M.R.; ZHOU, R.H.; WANG, J.B.; LI, M.H.; XU, J.; HOLMES, E.C.; ZHANG, Y.Z. Phylogeny and Origins of Hantaviruses Harbored by Bats, Insectivores, and Rodents. PLoS Pathogens. v.9, n.2, e1003159, 2013.

HALL, T. A. BioEdit: a user-friendly biological sequence alignment editor and analysis program for Windows 95/98/NT. Nucleic Acids Symposium Series. v. 41, p.95, 1999.

HINDRICHSEN, S.; MEDEIROS DE ANDRADE, A.; CLEMENT, J.; LEIRS, H.; MCKENNA, P.; MATTHYS, P.; NEILD, G.H. Hantavirus infection in Brazilian patients from Recife with suspected leptospirosis. Lancet. v.341, p.50, 1993.

HJELLE, B.; TORRES-PÉREZ, F. Hantaviruses in the Americas and Their Role as Emerging Pathogens. Viruses. v.2, p.2559-2586, 2010.

HOLMES, E.C. What does virus evolution tell us about virus origins? Journal of Virology. v.85, p.5247-5251, 2011. 
HOUCK, M.A.; QIN, H.; ROBERTS, H.R. Hantavirus transmission: potential role of ectoparasites. Vector Borne Zoonotic Diseases. v.1, n.1, p75-79, 2001.

HUANG, Y.; NIU, B.; GAO, Y.; FU, L.; LI, W. CD-HIT Suite: a web server for clustering and comparing biological sequences. Bioinformatics. v.26, p.680-682, 2010.

HUGHES, A.L.; FRIEDMAN, R. 2000. Evolutionary diversification of protein coding genes of hantaviruses. Molecular Biology and Evolution, v.17, p.1558-1568, 2000.

HUGOT, J.P.; PLYUSNINA, A.; HERBRETEAU, V.; NEMIROV, K.; LAAKKONEN, J.; LUNDKVIST, A.; SUPPUTAMONGKOL, Y.; HENTTONEN, H.; PLYUSNIN, A. Genetic analysis of Thailand hantavirus in Bandicota indica trapped in Thailand. Virology Journal, v.3, p.72, 2006.

IVERSSON, L. B.;da ROSA, A. P.; ROSA, M. D.; LOMAR, A. V.; SASAKI, M. G.; LEDUC, J. W. Human infection by Hantavirus in southern and southeastern Brazil. Revista da Associação Médica Brasileira. v.40, n.2, p.85-92, 1994

JÄÄSKELÄINEN, K.M.; PLYUSNINA, A.; LUNDKVIST, A.; VAHERI, A.; PLYUSNIN, A. Tula Hantavirus isolate with the full-length ORF for nonstructural protein NSs survives for more consequent passages in interferon-competent cells than the isolate having truncated NSs ORF. Virology Journal. v.11, p.3, 2008.

JAKAB, F.; SEBOK, J.; FERENCZI, E.; HORVÁTH, G.; SZUCS, G. First detection of Dobrava Hantavirus from a patient with severe haemorrhagic fever with renal syndrome by SYBR Green-based real time RT-PCR. Scandinavian Journal Infectious Diseases. v.39, p.902-906,2007.

JOHANSSON, P.; YAP, G.; LOW, H.T.; SIEW, C.C.; KEK, R.; NG, L.C.; BUCHT G. Molecular characterization of two hantavirus strains from different rattus species in Singapore. Virology Journal. v.7, p.15, 2010..

JOHNSON, A.M.; SOUZA, L.T.M.; FERREIRA, I.B.; PEREIRA, L.E.; KSIAZEK, T.G.; ROLLIN, P.E.; PETERS, C.J.; NICHOL, S.T. Genetic investigation of novel Hantaviruses causing fatal HPS in Brazil. Journal Medical Virology. v.59, p. 527-535, 1999.

JONSSON, C.; FIGUEIREDO, L.T.M.; VAPALAHTI, O. Hantavirus. A Global Perspective: Hantavirus Ecology, Epidemiology and Disease. Clinical Microbiology Reviews. v.23, p.412-41, 2010.

KARIWA， H.; YOSHIDA， H.; SÁNCHEZ-HERNÁNDEZ， C.; ROMERO-ALMARAZ, M.D.E. L.; ALMAZÁN-CATALÁN, J.A.; RAMOS, C.; MIYASHITA, D.; SETO, T.; TAKANO, A.; TOTANI, M.; MURATA, R.; SAASA, N.; ISHIZUKA, M.; SANADA, T.; YOSHII, K.; YOSHIMATSU, K.; ARIKAWA, J.; TAKASHIMA, I. Genetic diversity of hantaviruses in Mexico: identification of three novel hantaviruses from Neotominae rodents.Virus Research, v.163, n.2, p.486-494, 2012.

KLEMPA, B.; WITKOWSKI, P.T.; POPUGAEVA, E.; AUSTE, B.; KOIVOGUI, L.; FICHET-CALVET, E.; STRECKER, T.; TER MEULEN, J.; KRÜGER, D.H. Sangassou virus, the first hantavirus isolate from Africa, displays genetic and functional properties 
distinct from those of other murinae-associated hantaviruses. Journal of Virology. v.86, n.7, p.3819-3827, 2012.

KORVA, M.; DUH, D.; SAKSIDA, A.; TRILAR, T.; AVSIC-ZUPANC, T. The hantaviral load in tissues of naturally infected rodents. Microbes Infectious.v.11, n.3, p.344-351, 2009.

KRAMSKI, M.; MEISEL, H.; KLEMPA, B.; KRUGER, D.H.; PAULI, G.; NITSCHE, A. Detection and Typing of Human Pathogenic Hantaviruses by Real-Time Reverse Transcription-PCR and Pyrosequencing. Molecular Diagnostic Genetics. v.11, p.1899-1905, 2007.

KUMAR, S.; NEI, M.; DUDLEY, J.; TAMURA, K. MEGA: A biologist-centric software for evolutionary analysis of DNA and protein sequences. Brief Bioinformatics. v. 9, n.4, p.299306, 2008.

LEDUC, J.W.; SMITH, G.A.; PINHEIRO, F.P.; VASCONCELOS, P.F.; ROSA, E.S.; MAIZTEGUI, J.I. Isolation of Hantaan-related virus from Brazilian rats and serologic evidence of its widespread distribution in south America. American Journal of Tropical Medicine and Hygiene. v.34, p.810-815, 1985.

LEE, H.W., LEE, P.W.; BAEK, L.J.; SONG, C.K.; SEONG, I.W. Intraspecific transmission of Hantaan virus, etiologic agent of Korean hemorrhagic fever, in the rodent Apodemus agrarius. American Journal Tropical Medical Hygiene. v.30, p.1106-1112, 1981.

LEE, H.W.; LEE, P.W.; JOHNSON, K.M. Isolation of the etiologic agent of Korean hemorrhagic fever. Journal Infectious Diseases. v.137, p.298-308,1978.

LEUENROTH, S. Hantavirus pulmonary syndrome. $1^{\text {a }}$ Edition. Chelsea House Publishers. p.102. 2006

LI, W.; GODZIK, A. CD-HIT: a fast program for clustering and comparing large sets of protein or nucleotide sequences. Bioinformatics. v.22, p.1658-1659, 2006.

LIN, X.D.; WANG, W.; GUO, W.P.; ZHANG, X.H.; XING, J.G.;; CHEN, S.Z.; LI, M.H.; CHEN, Y.; XU, J.; PLYUSNIN, A.; ZHANG, Y.Z. Cross-species Transmission in the Speciation of the Currently Known Murinae-associated Hantaviruses. Journal of Virology, v.86, p.11171-11182, 2012.

MACKAY, I.M. Real-time PCR in the microbiology laboratory. Clinical Microbiology Infectious. v. 10, p.190-212, 2004.

MACKAY, I.M.; ARDEN, K.E.; NITSCHE, A. Real-time PCR in virology. Nucleic Acids Research. v.30, p.1292-130, 2002.

MACKOW, E.R.; GAVRILOVSKAYA, I.N. Hantavirus regulation of endothelial cell functions. Thrombosis and Haemostasis. v.102, n.6, p.1030-1041, 2009.

MALECKI, T.M.; JILLSON, G.P.; THILSTED, J.P.; ELROD, J.; TORREZ-MARTINEZ, N.; HJELLE, B. Serologic survey for hantavirus infection in domestic animals and coyotes from 
New Mexico and northeastern Arizona. Journal American Veterinary Medical Association. v.212, n.7, p.970-973, 1998.

MARTINEZ, V.P.; BELLOMO, C.; SAN JUAN, J.; PINNA, D.; FORLENZA, R.; ELDER, M.; PADULA, P.J. Person-to-person transmission of Andes virus. Emerging Infectious Diseases. v.11, n.12, p.1848-53, 2005.

MENDES, W.S.; ARAGÃO, N.J.; SANTOS, H.J.; RAPOSO, L.; VASCONCELOS, P.F.; ROSA, E.S; ELKHOURY, M.R. Hantavírus pulmonary syndrome in Anajatuba, Maranhão, Brasil. Revista do Instituto de Medicina Tropical de São Paulo. v.43, p.237-240, 2001.

MINISTÉRIO DA SAÚDE. Acesso em 19 de novembro de 2012. Disponível em < www. portal.saude.gov.br. >

MIR, M. Hantavirus. Clinical Laboratory Medical. v.30, n.1, p.67-91, 2010.

MORELI, L.M.; SOUSA, R.L.M.; FIGUEIREDO, L.T.M. Detection of Brazilian Hantavirus by reverse transcription polymerase chain reaction amplification of $\mathrm{N}$ gene in patients with Hantavirus cardiopulmonary syndrome. Memórias do Instituto Oswaldo Cruz. v.99,n.6,p.633-638, 2004.

MOHAMED, N.; NILSSON, E.; JOHANSSON, P.; KLINGSTRÖM, J.; EVANDER, M.; AHLM, C.; BUCHT G. Development and evaluation of a broad reacting SYBR-green based quantitative real-time PCR for the detection of different hantaviruses. Journal of Clinical Virology. 2013.

MUSSER, G.G.; CARLETON, M.D. 2005. Superfamily Muroidea. Pp. 894-1531 in Wilson, D.E. \& Reeder, D.M. (eds.). Mammal Species of the World: a taxonomic and geographic reference. 3rd ed. Baltimore: The Johns Hopkins University Press, 2 vols., 2142 pp.

NÄSLUND, J.; KERNER, A.; DROBNI, P.; BUCHT, G.; EVANDER, M.; AHLM, C. Detection of Puumala and Rift Valley Fever virus by quantitative RT-PCR and virus viability tests in samples of blood dried and stored on filter paper. Journal Virological Methods. v.178, p.186-190, 2011

NEMIROV, K.; HENTTONEN, H.; VAHERI, A.; PLYUSNIN, A. Phylogenetic evidence for host switching in the evolution of hantaviruses carried by Apodemus mice. Virus Research. v.90, p. 207-215, 2002.

NICHOL, S.T.; SPIROPOULOU, C.F.; MORZUNOV, S.; ROLLIN, P.E.; KSIAZEK, T.G.; FELDMANN, H.; SANCHEZ, A.; CHILDS, J.; ZAKI, S.; PETERS, C.J. Genetic identification of a Hantavirus associated with an outbreak of acute respiratory illness. Science. v.262, p.914-917, 1993.

PADUlA, P. J.; EDELSTEIN, A.; MIGUEL, S. D. L.; LÓPEZ, N. M.; ROSSI, C. M.; RABINOVICH, R. D. Hantavirus pulmonary syndrome outbreak in Argentina: Molecular evidence for person-to-person transmission of Andes virus. Virology. v. 241, p. 323-330, 1998. 
PADULA, P.; FIGUEROA, R.; NAVARRETE, M.; PIZARRO, E.; CADIZ, R.; BELLOMO, C.; JOFRE, C.; ZAROR, L.; RODRIGUEZ, E.; MURÚA, R.. Transmission study of Andes hantavirus infection in wild sigmodontine rodents. Journal of Virology. v.78,p.11972$11979,2004$.

PAPA, A. Dobrava-Belgrade virus: Phylogeny, epidemiology, disease, Antiviral Research, v.95, n.2, p.104-117, 2012.

PAPIN, J.F.; VAHRSON, W.; DITTMER, D.P. SYBR green-based real-time quantitative PCR assay for detection of West Nile Vírus circumvents false-Negativo results due to strain variability. Journal Clinical Microbiology. v.42,n.4, p.1511-1518, 2004.

PARADA, A.; PARDIÑAS, U.F.; SALAZAR-BRAVO, J.; D'ELÍA, G.; PALMA, R.E. Dating an impressive Neotropical radiation: Molecular time estimates for the Sigmodontinae (Rodentia) provide insights into its historical biogeography. Molecular Phylogenetic Evolution, v.66, n.3, p.960-968, 2013.

PLYUSNIN, A.; MORZUNOV, S.P. Virus evolution and genetic diversity of hantaviruses and their rodent hosts. Current Topical Microbiology Immunology. v.256, p.47-75, 2001.

POSADA, D. jModelTest: Phylogenetic Model Averaging. Molecular Biology Evolution. v.25, n.7, p.1253-1256, 2008.

PRYOR, R.J.; WITTWER, C.T. Real- time polymerase chain reaction and melting curve analysis. Methods Molecular Biology. v.336, p.19-32, 2006.

RABONI, S.M.; DE BORBA, L.; HOFFMANN, F.G.; DE NORONHA, L.; AZEVEDO, M.L.; CARSTENSEN, S.; MAZZAROTTO, G.A.; BORDIGNON, J.; DOS SANTOS, C.N. Evidence of circulation of Laguna Negra-like Hantavirus in the Central West of Brazil: case report. Journal Clinical Virology. v.45, n.2, p.153-156, 2009A.

RABONI, S.M.; HOFFMANN, F.G.; OLIVEIRA, R.C.; TEIXEIRA, B.R.; BONVICINO, C.R.; STELLA, V.; CARSTENSEN, S.; BORDIGNON, J.; D'ANDREA, P.S.; LEMOS, E.R.; DUARTE DOS SANTOS, C.N. Phylogenetic characterization of Hantaviruses from wild rodents and Hantavirus pulmonary syndrome cases in the state of Paraná (southern Brazil). Journal General Virology. v.90, p.2166-2171, 2009B.

RAMSDEN, C.; HOLMES, E.C.; CHARLESTON, M.A. Hantavirus evolution in relation to its rodent and insectivore hosts: no evidence for codivergence. Molecular Biology and Evolution. v.26, n.1, p.143-153, 2009.

RAMSDEN, C.; MELO, F. L.; FIGUEIREDO, L. T. M.; HOLMES, E. D.; ZANOTTO, P. M. A.;AND VGDN CONSORTIUM. High Rates of Molecular Evolution in Hantaviruses. Molecular Biology and Evolution. v.25, n.7, p.1488-1492, 2008.

REIG, O. A. Distribuição geográfica e história evolutivas dos roedores Muroideos sulamericanos (Cricetidae: Sigmodontinae). Revista Brasileira de Genética 7(2):333365,1984 . 
RODRIGUEZ, F.; OLIVER, J.L.; MARIN, A.; MEDINA, J.R. The general stochastic model of nucleotide substitution. Journal Theory Biology. v.142, p.485-501,1990.

SABINO-SANTOS JR, G. Detecção de Hantavírus em roedores silvestres e estudo de sua dinâmica populacional na região Nordeste do Estado de São Paulo. 2010. Dissertação. Universidade de São Paulo. 2010.

SAKSIDA, A.; DUH, D.; KORVA, M.; AVSIC-ZUPANC, T. Dobrava vírus RNA load in patients who have Hemorrhagic Fever with Renal Syndrome. The Journal of Infectious Diseases. v.197, p.681-685, 2008.

SCHLEGEL, M.; KINDLER, E.; ESSBAUER, S.S.; WOLF, R.; THIEL, J.; GROSCHUP, M.H.; HECKEL, G.; OEHME, R.M.; ULRICH, R.G. Tula Vírus Infections in the Eurasian Water Vole in Central Europe. Vector Borne Zoonotic Diseases. v.12, n.6, p.503-13, 2012.

SCHÖNRICH, G.; RANG, A.; LÜTTEKE, N.; RAFTERY, M.J.; CHARBONNEL, N.; ULRICH, R.G. Hantavirus-induced immunity in rodent reservoirs and humans. Immunology Reviews. v.225, p.163-189, 2008.

SLONOVA, R.A.; TKACHENKO, E.A.; KUSHNAREV, E.L.; DZAGUROVA, T.K.; ASTAKOVA, T.I. Hantavirus isolation from birds. Acta Virology. v.36, n.5, p.493, 1992.

SONG, W.; TORREZ-MARTINEZ, N.; IRWIN, W.; HARRISON, F.J.; DAVIS, R.; ASCHER, M.; JAY, M.; HJELLE, B. Isla Vista virus: a genetically novel hantavirus of the California vole Microtus californicus. Journal General Virology, v.76, n.12, p.3195-3199, 1995.

SOUSA, R.L.M.; MORELI, M.L.; BORGES, A.A.; CAMPOS, G.M.; LIVONESI, M.C.; FIGUEIREDO, L.T.M.; PINTO, A.A. Natural host relationship and genetic diversity of rodent associated Hantavíruses in Southeastern Brazil. Intervirology. v.51, p.299-310, 2008.

SUZUKI, A.; BISORDI, I.; LEVIS, S.; GARCIA, J.;. PEREIRA, L.E; SOUZA, R.P., SUGAHARA, T.K.; PINI, N.; ENRIA, D.; SOUZA, L.T. Identifying rodent Hantavírus reservoirs, Brazil. Emerging Infectious Diseases. v.10, n.12, p.2127-2134, 2004.

TAMURA K., PETERSON D., PETERSON N., STECHER G., NEI M., KUMAR S. MEGA 5: Molecular Evolutionary Genetics Analysis using Maximum Likelihood, Evolutionary Distance, and Maximum Parsimony Methods. Molecular Biology and Evolution. 2011.

THOMPSON, J.D.; HIGGINS, D.G.; GIBSON, T.J. CLUSTAL W: improving the sensitivity of progressive multiple sequence alignment through sequence weighting, position-specific gap penalties and weight matrix choice. Nucleic Acids Research. v.11, p.22, p.4673-4680, 1994.

TRAVASSOS DA ROSA, E.S.; MEDEIROS, D.B.; NUNES, M.R.; SIMITH, D.B.; SOUZA, D.E.; PEREIRA, A.; ELKHOURY, M.R.; LAVOCAT, M.; MARQUES, A.A.; VIA, A.V.; D'ANDREA, P.; BONVICINO, C.R.; LEMOS, E.R.; VASCONCELOS, P.F.Pygmy Rice Rat as Potential Host of Castelo dos Sonhos Hantavirus. Emerging Infectious Diseases. v. 17, p. 1527-1530, 2011. 
TRAVASSOS DA ROSA, E.S.; MILLS, J.N.; PADULA, P.J.; ELKHOURI, M.R.; KSIAZEK, T.G.; MENDES, W.S.; SANTOS, E.D.; ARAUJO, G.C.; MARTINEZ, V.P.; ROSA, J.F.; EDELSTEIN, A.; VASCONCELOS, P.F. Newly recognized Hantaviruses associated with Hantavirus pulmonary syndrome in northern Brazil: partial genetic characterization of viruses and serologic implication of likely reservoirs. Vector Borne Zoonotic Disease. v.5, n.1, p.11-19, 2005.

TROMBLEY, A.R.; WACHTER, L.; GARRISON, J.; BUCKLEY-BEASON, V.A.; JAHRLING, J.; HENSLEY, L.E.; SCHOEPP, R.J.; NORWOOD , D.A.; GOBA, A.; FAIR, J.N.; KULESH, D.A. Comprehensive panel of real-time TaqMan Polymerase Chain Reaction assays for detection and absolute quantification of filoviruses, arenaviruses, and new world Hantaviruses. American Journal Tropical Medical Hygiene v.82, p.954-960, 2010.

VAPALAHTI, O.; MUSTONEN, J.; LUNDKVIST, A.; HENTTONEN, H.; PLYUSNIN, A.; VAHERI, A. Hantavirus infections in Europe. Lancet Infectious Diseases. v.3, p.653-661, 2003.

VASCONCELOS, P.F.C.; TRAVASSOS DA ROSA, E.S.; TRAVASSOS DA ROSA, A.P.A.; TRAVASSOS DA ROSA, J.F.S. Evidence of circulating Hantaviruses in Brazilian Amazonia through high prevalence of antibodies in residents of Manaus, Brazil. Ciência Cultura. v.44, p.162-163, 1992.

VERA-OTAROLA, J.; SOLIS, L.; SOTO-RIFO, R.; RICCI, E.P.; PINO, K.; TISCHLER, N.D.; OHLMANN, T.; DARLIX, J.L.; LÓPEZ-LASTRA, M. The Andes Hantavirus NSs Protein Is Expressed from the Viral Small mRNA by a Leaky Scanning Mechanism. Journal Virology. v.86, n.4, p.2176-2187, 2012.

VIRTANEN, J.O.; JÄÄSKELÄINEN, K.M.; DJUPSJÖBACKA， J.; VAHERI, A.; PLYUSNIN, A. Tula Hantavirus NSs protein accumulates in the perinuclear area in infected and transfected cells. Archives Virology. v.155, n.1, p.117-121, 2010.

WALTER, C.T.; BARR, J.N. Recent advances in the molecular and cellular biology of bunyaviruses. Journal General Virology. v.92, p.2467-2484, 2011.

WEISS, S.; WITKOWSKI, P.T.; AUSTE, B.; NOWAK, K.; WEBER, N.; FAHR, J.; MOMBOULI, J.V.; WOLFE, N.D.; DREXLER, J.F.; DROSTEN, C.; KLEMPA, B.; LEENDERTZ, F.H.; KRUGER, D.H. Hantavirus in bat, sierra leone. Emerging Infectious Diseases. v.18, n.1, p.159-161, 2012.

WEKSLER, M.; PERCEQUILLO, A.R.; VOSS, R.S. Ten new genera of oryzomyine rodents (Cricetidae, Sigmodontinae). American Museum Novitates. v. 10024, n. 3537, p.1-29.2006.

WILSON, D. E.; REEDER, D. M. 2005. Mammal Species of the World. A Taxonomic and Geographic Reference. (3rd ed) Johns Hopkins University Press. v.2, p.2000, 2005.

XIA, X.; XIE, Z. DAMBE: Data analysis in molecular biology and evolution. Journal of Heredity. v.92, p.371-373, 2001.

YANAGIHARA, R.; DAUM, C.A.; LEE, P.W.; BAEK, L.J.; AMYX, H.L.; GAJDUSEK, D.C.; GIBBS, C.J.;. Serological survey of Prospect Hill virus infection in indigenous wild 
rodents in the USA. Royal Society of Tropical Medicine and Hygiene. v.8, n.1, p.42-5, 1987.

YANG, Z; RANNALA, B. Molecular phylogenetics: principles and practice. Nature Reviews Genetics. v.13, p.303-314, 2012,

ZEIER, M.; HANDERMANN, M.; BAHR, U.; RENSCH, B.; MÜLLER, S.; KEHM, R.; MURANY, W.; DARA, G. New Ecological Aspects of Hantavírus Infection: A Change of a Paradigmand a Challenge of Prevention. Vírus Genes. v.30, n.2, p.157-180, 2005. 
APÊNDICE A - Informações sobre as sequências do segmento $S$

\begin{tabular}{|c|c|c|c|c|c|}
\hline Código & N.Genbank & $\begin{array}{l}\text { Ano de } \\
\text { coleta }\end{array}$ & País & Cidade ou Região & Reservatório \\
\hline 1999.RU.AF367064_PUV & AF367064.1 & 1999 & Russia & Omsk region & Clethrionomys glareolus \\
\hline $\begin{array}{l}\text { 1999.RU.AF367071_PUV } \\
\end{array}$ & AF367071.1 & 1999 & Russia & Omsk region & Clethrionomys rufocanus \\
\hline 1999.RU.AF367070_PUV & $\underline{\mathrm{AF} 367070.1}$ & 1999 & Russia & Omsk region & Clethrionomys rufocanus \\
\hline 1999.RU.AF367068_PUV & $\underline{\mathrm{AF} 367068.1}$ & 1999 & Russia & Omsk region & Clethrionomys rufocanus \\
\hline 2000.RU.AF367066_PUV & AF367066.1 & 2000 & Russia & Omsk region & Clethrionomys glareolus \\
\hline 2000.RU.AF367067_PUV & $\underline{\mathrm{AF} 367067.1}$ & 2000 & Russia & Omsk region & Clethrionomys rufocanus \\
\hline 2000.RU.AF367065_PUV & $\underline{\mathrm{AF} 367065.1}$ & 2000 & Russia & Omsk region & Clethrionomys glareolus \\
\hline 1991.FI.NC_005224_PUV & NC 005224.1 & 1991 & Finland & Sotkamo, Northern & Human case \\
\hline 2000.FI.GU808825_PUV & $\underline{\text { GU808825.1 }}$ & 2000 & Finland & & Myodes glareolus \\
\hline 2000.FI.GU808824_PUV & $\underline{\text { GU808824.1 }}$ & 2000 & Finland & & Myodes glareolus \\
\hline 2008.LE.JN657228_PUV & JN657228 & 2008 & Letonia & Madona & Myodes glareolus \\
\hline 2004.SW.AY526219_PUV & AY526219.1 & 2004 & Sweden & & Not determined \\
\hline 2005.SW.GQ339481_PUV & GQ339481.1 & 2005 & Sweden & North & Myodes glareolus \\
\hline 2005.SW.GQ339480_PUV & GQ339480.1 & 2005 & Sweden & North & Myodes glareolus \\
\hline 2005.SW.GQ339479_PUV & GQ339479.1 & 2005 & Sweden & North & Myodes glareolus \\
\hline 2005.SW.GQ339478_PUV & GQ339478.1 & 2005 & Sweden & North & Myodes glareolus \\
\hline 2005.SW.GQ339482_PUV & GQ339482.1 & 2005 & Sweden & North & Myodes glareolus \\
\hline 2005.SW.GQ339475_PUV & GQ339475.1 & 2005 & Sweden & North & Myodes glareolus \\
\hline 2005.SW.GQ339474_PUV & GQ339474.1 & 2005 & Sweden & North & Myodes glareolus \\
\hline 2005.SW.GQ339476_PUV & GQ339476.1 & 2005 & Sweden & North & Myodes glareolus \\
\hline 2005.SW.GQ339477_PUV & GQ339477.1 & 2005 & Sweden & North & Myodes glareolus \\
\hline 2005.SW.GQ339473_PUV & GQ339473.1 & 2005 & Sweden & North & Myodes glareolus \\
\hline 2005.RU.AB433843_PUV & $\underline{\mathrm{AB} 433843.2}$ & 2005 & Russia & Samara region & Myodes glareolus \\
\hline 2005.RU.AB433845_PUV & $\mathrm{AB} 433845.2$ & 2005 & Russia & Samara region & Myodes glareolus \\
\hline 1993.RU.L08804_PUV & $\underline{\mathrm{L} 08804.1}$ & 1993 & Russia & & Human case \\
\hline 2001.RU.AF442613_PUV & $\underline{\mathrm{AF} 442613.1}$ & 2001 & Russia & $\begin{array}{c}\text { Bashkortostan, } \\
\text { Blagoveshchenskiy }\end{array}$ & Clethrionomys glareolus \\
\hline 2008.LA.JN657232_PUV & JN657232 & 2008 & Letonia & Madona & Myodes glareolus \\
\hline 2008.LA.JN657229_PUV & JN657229 & 2008 & Letonia & Madona & Myodes glareolus \\
\hline 2008.LA.JN657230_PUV & JN657230 & 2008 & Letonia & Madona & Myodes glareolus \\
\hline 2008.LA.JN657231_PUV & JN657231 & 2008 & Letonia & Jelgava & Myodes glareolus \\
\hline 2004.SL.AF294652_PUV & $\underline{\mathrm{AF} 294652.1}$ & 2000 & Slovakia & Slovakia & Clethrionomys glareolus \\
\hline 2004.GE.DQ016432_PUV & DQ016432.2 & 2004 & Germany & Lower Bavaria & Clethrionomys glareolus \\
\hline 2004.GE.DQ016430_PUV & DQ016430.2 & 2004 & Germany & Lower Bavaria & Clethrionomys glareolus \\
\hline 2005.SW.GQ339484_PUV & GQ339484.1 & 2005 & Sweden & central & Myodes glareolus \\
\hline 2005.SW.GQ339483_PUV & GQ339483.1 & 2005 & Sweden & North & Myodes glareolus \\
\hline 2005.SW.GQ339485_PUV & GQ339485.1 & 2005 & Sweden & southern & Myodes glareolus \\
\hline 2005.SW.GQ339487_PUV & GQ339487.1 & 2005 & Sweden & southern & Myodes glareolus \\
\hline 2005.SW.GQ339486_PUV & GQ339486.1 & 2005 & Sweden & southern & Myodes glareolus \\
\hline 1998.RU.AB675480_HOV & $\underline{\mathrm{AB} 675480.1}$ & 1998 & Russia & $\begin{array}{l}\text { Sakhalin, Yuzhno- } \\
\text { Sakhalinsk } \\
\end{array}$ & $\begin{array}{c}\text { Myodes rufocanus } \\
\text { bedfordiae }\end{array}$ \\
\hline 1998.RU.AB675453_HOV & AB675453 & 1998 & Russia & $\begin{array}{c}\text { Sakhalin, Yuzhno- } \\
\text { Sakhalinsk }\end{array}$ & $\begin{array}{c}\text { Myodes rufocanus } \\
\text { bedfordiae }\end{array}$ \\
\hline 2010.JA.AB675479_HOV & $\underline{\mathrm{AB} 675479}$ & 2010 & Japan & Hokkaido, Shari & Apodemus speciosus \\
\hline 2000.JA.AB675474_HOV & AB675474 & 2000 & Japan & Hokkaido, Kiritappu & $\begin{array}{c}\text { Myodes rufocanus } \\
\text { bedfordiae }\end{array}$ \\
\hline 2009.JA.AB675469_HOV & AB675469 & 2009 & Japan & Hokkaido, Ishikari Port & $\begin{array}{c}\text { Myodes rufocanus } \\
\text { bedfordiae }\end{array}$ \\
\hline 2004.JA.AB675465_HOV & AB675465 & 2004 & Japan & Hokkaido, Tobetsu & $\begin{array}{c}\text { Myodes rufocanus } \\
\text { bedfordiae }\end{array}$ \\
\hline 2010.JA.AB675450_HOV & $\underline{\mathrm{AB} 675450.1}$ & 2010 & Japan & Hokkaido, Tobetsu & $\begin{array}{c}\text { Myodes rufocanus } \\
\text { bedfordiae }\end{array}$ \\
\hline 2004.JA.AB675471_HOV & $\underline{\mathrm{AB} 675471}$ & 2004 & Japan & Hokkaido, Nakawaga & $\begin{array}{c}\text { Myodes rufocanus } \\
\text { bedfordiae }\end{array}$ \\
\hline 1995.JA.AB010731_PUV & $\underline{\mathrm{AB} 010731.1}$ & 1995 & Japan & Tobetsu, Hokkaido & Clethrionomys rufocanus \\
\hline 1995.JA.AB010730_PUV & $\underline{\mathrm{AB} 010730.1}$ & 1995 & Japan & Kamiiso, Hokkaido & Clethrionomys rufocanus \\
\hline 2008.RU.AB675463_HOV & AB675463 & 2008 & Russia & $\begin{array}{l}\text { Sakhalin, Yuzhno- } \\
\text { Sakhalinsk }\end{array}$ & $\begin{array}{c}\text { Myodes rufocanus } \\
\text { bedfordiae }\end{array}$ \\
\hline
\end{tabular}




\begin{tabular}{|c|c|c|c|c|c|}
\hline 2010.JA.AB675477_HOV & AB675477.1 & 2010 & Japan & Hokkaido, Shari & Apodemus speciosus \\
\hline 2010.JA.AB675478_HOV & AB67578 & 2010 & Japan & Hokkaido, Shari & $\begin{array}{l}\text { Myodes rufocanus } \\
\text { bedfordiae }\end{array}$ \\
\hline 2003.CH.EF442087_PUV & EF442087.1 & 2003 & China & Jilin province & Clethrionomys rufocanus \\
\hline 2003.CH.EF442091_PUV & EF442087.1 & 2003 & China & Jilin province & Clethrionomys rufocanus \\
\hline 2002.CH.AB677477_USV & $\underline{\mathrm{AB} 677477}$ & 2002 & Russia & Khabarovsk, Khekhtsir & Myodes rufocanus \\
\hline 1998.RU.AB677476_USV & AB677476 & 1998 & Russia & Khabarovsk, Khekhtsir & Myodes rufocanus \\
\hline 1999.SC.DQ138133_MJV & DQ138133.1 & 1999 & $\begin{array}{l}\text { South } \\
\text { Korea }\end{array}$ & Muju, Jeollabuk & Eothenomys regulus \\
\hline 2000.SC.DQ138128_MJV & DQ138128.1 & 2000 & $\begin{array}{l}\text { South } \\
\text { Korea }\end{array}$ & Muju, Jeollabuk & Eothenomys regulus \\
\hline 1999.SC.DQ138142_MUV & DQ138142.1 & 1999 & $\begin{array}{l}\text { South } \\
\text { Korea }\end{array}$ & Muju, Jeollabuk & Eothenomys regulus \\
\hline 1999.SC.DQ138140_MJV & DQ138140.1 & 1999 & $\begin{array}{l}\text { South } \\
\text { Korea }\end{array}$ & Muju, Jeollabuk & Eothenomys regulus \\
\hline 2006.CH.EU072482_YAV & EU072482 & 2006 & China & $\begin{array}{c}\text { Inner Mongolia } \\
\text { Autonomous Region, } \\
\text { Yakeshi }\end{array}$ & Microtus ma. \\
\hline 2006.CH.EU072484_YAV & EU072484 & 2006 & China & $\begin{array}{c}\text { Inner Mongolia } \\
\text { Autonomous Region, } \\
\text { Yakeshi }\end{array}$ & Microtus maximowiczii \\
\hline 1994.RU.U35255_KHV & U35255.1 & 1994 & Russia & Khabarovsk region & Microtus fortis \\
\hline 2002.CH.FJ170797_SHV & FJ170797.1 & 2002 & China & Liaoning & Microtus fortis \\
\hline 2002.CH.FJ170796_SHV & FJ170796.1 & 2002 & China & Liaoning & Microtus fortis \\
\hline 2007.CH.FJ170792_YUV & $\underline{\text { FJ170792.1 }}$ & 2007 & China & Hunan & Microtus fortis \\
\hline 2006.CH.FJ170794_YUN & FJ170794.1 & 2006 & China & Hunan & Microtus fortis \\
\hline 2007.CH.FJ170795_YUV & FJ170795.1 & 2007 & China & Hunan & Microtus fortis \\
\hline 2007.CH.FJ170793_YUV & FJ170793.1 & 2007 & China & Hunan & Microtus fortis \\
\hline 1994.US.U31535_ISV & U31535.1 & 1994 & USA & $\begin{array}{c}\text { Santa Barbara and San } \\
\text { Diego }\end{array}$ & Microtus californicus \\
\hline 1994.US.U31534_ISV & U31534.1 & 1994 & $\overline{\text { USA }}$ & $\begin{array}{c}\text { Santa Barbara and San } \\
\text { Diego }\end{array}$ & Microtus californicus \\
\hline 1997.SE.AF017659_TUV & $\underline{\mathrm{AF} 017659.1}$ & 1997 & Serbia & Cacak region & Pitymys subterraneus \\
\hline 2000.CR.AF164094_TUV & AF164094.1 & 2000 & Croatia & & Microtus arvalis \\
\hline 1995.CZ.NC_005227_TUV & NC 005227.1 & 1995 & $\begin{array}{c}\text { Czech } \\
\text { Republic }\end{array}$ & Moravia & Human case \\
\hline 1997.GE.AF164093_TUV & AF164093.1 & 1997 & Germany & $\begin{array}{l}\text { Brandenburg, Lower } \\
\text { Saxony and Bavaria }\end{array}$ & Microtus arvalis \\
\hline 2003.KA.AM945877_TUV & AM945877.1 & 2003 & Kazakhstan & Eastern Kazakhstan & Microtus arvalis obscurus \\
\hline 1995.PO.AF063897_HTV & $\underline{\mathrm{AF} 063897.1}$ & 1995 & Poland & Lodz and T uszyn & Microtus arvalis \\
\hline 1995.PO.AF063892_HTV & AF063892.1 & 1995 & Poland & Lodz and Tuszyn & Microtus arvalis \\
\hline 2003.GE.AF289819_TUV & $\underline{\mathrm{AF} 289819.1}$ & 2003 & Germany & Cottbus, Northern & Human case \\
\hline 2003.GE.AF289821_TUV & AF289821.1 & 2003 & Germany & Cottbus, Northern & Human case \\
\hline 2003.GE.AF289820_TUV & $\overline{\mathrm{AF} 289820.1}$ & 2003 & Germany & Cottbus, Northern & Human case \\
\hline 2006.ME.AB620093_CRV & $\underline{\mathrm{AB} 620103}$ & 2006 & Mexico & states of Guerrero & Peromyscus megalops \\
\hline 2006.ME.AB620103_CRV & AB620103 & 2006 & Mexico & states of Guerrero & Peromyscus megalops \\
\hline 2006.ME.AB620106_HZV & AB620106.1 & 2006 & Mexico & Huitzilac & Reithrodontomys megalotis \\
\hline 1994.US.U11427_ELV & $\underline{\mathrm{U} 11427.1}$ & 1994 & USA & Orange County & Reithrodontomys megalotis \\
\hline 1989.CR.RMU18100_RSV & $\underline{\text { RMU18100 }}$ & 1989 & Costa Rica & Rio Segundo & $\begin{array}{l}\text { Reithrodontomys } \\
\text { mexicanus }\end{array}$ \\
\hline 2006.ME.AB620089_MOV & $\underline{\mathrm{AB} 20089.1}$ & 2006 & Mexico & State of Guerrero & Peromyscus beatae \\
\hline 2006.ME.AB620100_MOV & $\mathrm{AB} 20100$ & 2006 & Mexico & State of Guerrero & Peromyscus beatae \\
\hline 2006.ME.AB620085_MOV & $\underline{\mathrm{AB} 20085.1}$ & 2006 & Mexico & State of Guerrero & Peromyscus beatae \\
\hline 2006.ME.AB620091_MOV & $\underline{\mathrm{AB} 20091.1}$ & 2006 & Mexico & State of Guerrero & Peromyscus beatae \\
\hline 2006.ME.AB620087_MOV & $\underline{\mathrm{AB} 20087.1}$ & 2006 & Mexico & State of Guerrero & Peromyscus beatae \\
\hline 1993.US.NC_005216_SNV & NC 005216.1 & 1993 & USA & $\begin{array}{c}\text { New Mexico, Arizona, } \\
\text { Colorado }\end{array}$ & Human case \\
\hline 1993.US.L25784_SNV & $\underline{\mathrm{L} 25784.1}$ & 1993 & $\overline{\text { USA }}$ & Four Corners & Human case \\
\hline 1994.US.L37904_SNV & $\underline{\underline{L} 37904.1}$ & 1994 & $\overline{\text { USA }}$ & West Virginia & Peromyscus maniculatus \\
\hline 1995.US.U29210_SNV & $\underline{\mathrm{U} 29210.1}$ & 1995 & $\overline{\text { USA }}$ & Shelter Island, New York & Peromyscus leucopus \\
\hline 1985.US.U32591_MHV & U32591.1 & 1985 & $\overline{\text { USA }}$ & West Virginia & $\begin{array}{c}\text { Peromyscus maniculatus } \\
\text { nubiterrae }\end{array}$ \\
\hline 2006.US.JN196142_HUV & JN196142 & 2006 & $\overline{\text { USA }}$ & $\begin{array}{c}\text { Great Smoky Mountain } \\
\text { region }\end{array}$ & Peromyscus leucopus \\
\hline
\end{tabular}




\begin{tabular}{|c|c|c|c|c|c|}
\hline 2006.US.JN196141_HUV & $\underline{\mathrm{JN} 196141}$ & 2006 & USA & $\begin{array}{c}\text { Great Smoky Mountain } \\
\text { region }\end{array}$ & Peromyscus leucopus \\
\hline 2006.US.JN196140_HUV & JN196140 & 2006 & USA & $\begin{array}{c}\text { Great Smoky Mountain } \\
\text { region }\end{array}$ & Peromyscus leucopus \\
\hline 1994.VE.DQ285566_CDV & DQ285566.1 & 1994 & Venezuela & $\begin{array}{c}\text { Cano Delgadito, State of } \\
\text { Portuguese }\end{array}$ & Sigmodon alstoni \\
\hline 1996.PE.FJ532244_RMV & FJ532244.1 & 1996 & Peru & Iquitos in northeastern & Oligoryzomys microtis \\
\hline 1992.BO.U52136_RMV & U52136.1 & 1992 & Bolivia & La Paz & Oligoryzomys microtis \\
\hline 1995.PA.DQ345762_ALP & DQ345762.1 & 1995 & Paraguay & Alto Paraguay & Holochilus chacarius \\
\hline 2008.BR.FJ816031_LNV & FJ816031.1 & 2008 & Brazil & & Human case \\
\hline 2000.PA.DQ285046_CHV & DQ285046.1 & 2000 & Panama & $\begin{array}{c}\text { Las Tablas, Los Santos } \\
\text { Province }\end{array}$ & Oligoryzom ys fulvescens \\
\hline 2006.BR.JN232078_JAV & $\mathrm{JN} 232078$ & 2006 & Brazil & Jabora, Santa Catarina & Akodon paranaensis \\
\hline 2006.BR.JN232079_JAV & JN232078 & 2006 & Brazil & Jabora, Santa Catarina & Akodon paranaensis \\
\hline 2006.BR.JN232080_JAV & JN232080 & 2006 & Brazil & Jabora, Santa Catarina & Akodon paranaensis \\
\hline 2003.BR.03R11_ARV & $\begin{array}{c}\text { Não } \\
\text { submetido }\end{array}$ & 2003 & Brazil & State São Paulo & Necromys lasiurus \\
\hline 2006.BR.06 & $\begin{array}{c}\text { Não } \\
\text { submetido }\end{array}$ & 2006 & Brazil & Stat & $\mathrm{Cal}$ \\
\hline 2004.BR.EF571895_ARV & EF571895.1 & 2007 & Brazil & Cajuru, Sao Paulo State & Necromys lasiurus \\
\hline 2004.BR.EF576661_PAV & EF576661.1 & 2004 & Brazil & Paranoa, Distrito Federal & Human case \\
\hline 1997.AR.AF482716_MCV & AF482716.1 & 1997 & Argentina & Maciel & Necromys benefactus \\
\hline 1997.AR.AF482717_PEV & AF482717.1 & 1997 & Argentina & Pergamino & Akodon azarae \\
\hline 2008.BO.JF750418_TNV & JF750418.1 & 2008 & Bolivia & Villa Tunari & Human case \\
\hline 2008.BO.JF750419_TNV & JF750418.1 & 2008 & Bolivia & Villa Tunari & Human case \\
\hline 2008.BO.JF750417_TNV & JF750417.1 & 2008 & Bolivia & Villa Tunari & Human case \\
\hline 2008.BO.JF750417_TNV & $\underline{\mathrm{JF} 750417}$ & 2008 & Bolivia & Villa Tunari & Human case \\
\hline 2004.BR.AY740633_AUV & AY740633.1 & 2004 & Brazil & Barbosa Ferraz, Parana & Human case \\
\hline 2004.BR.AY740625_AUV & AY740625.1 & 2002 & Brazil & General Carneiro, Parana & Human case \\
\hline 2003.BR.AY740628_AUV & & 2003 & Brazil & State Parana & \\
\hline 2003.BR.AY740630_AUV & AY740630.1 & 2003 & Brazil & Guarapuava, Parana & Human case \\
\hline 2002.BR.AY740626_AUV & AY740626.1 & 2002 & Brazil & Brazil & Human case \\
\hline 2002.BR.AY740624_AUV & AY740624.1 & 2002 & Brazil & General Carneiro, Parana & Human case \\
\hline 2002.BR.AY740627_AUV & & 2002 & Brazil & State Parana & \\
\hline 2001.BR.AY740623_AUV & AY740623.1 & 2001 & Brazil & Guarapuava, Parana & Human case \\
\hline 2003.BR.AY740629_AUV & AY740629.1 & 2003 & Brazil & São Mateus do Sul, Parana & Human case \\
\hline 1995.PA.DQ345765_ITV & DQ345765.1 & 1995 & Paraguay & Itapua, western & Oligoryzomys nigripes \\
\hline 1995.PA.DQ345766_ITV & DQ345766.1 & 1995 & Paraguay & Itapua, western & Olygoryzomys nigripes \\
\hline 1995.AR.AF324902_ANV & $\underline{\mathrm{AF} 324902.1}$ & 1995 & Argentina & Southwestern & Human case \\
\hline 1995.AR.AF004660_ANV & AF004660.1 & 1995 & Argentina & Southwestern & \\
\hline 1999.CL.AY228237_ANV & AY228237.1 & 1999 & Chile & & Human case \\
\hline 1997.CL.AF482712_ANV & AF482712.1 & 1997 & Chile & Aysen & Human case \\
\hline 1999.CL.AF291702_ANV & $\underline{\mathrm{AF} 291702.1}$ & 1997 & Chile & & $\begin{array}{l}\text { Oligoryzomys } \\
\text { longicaudatus }\end{array}$ \\
\hline 1997.AR.AF325966_ANV & AF325966.1 & 1997 & Argentina & Jujuy and Salta & Oligoryzomys chacoensis \\
\hline 1997.CL.NC_003466_ANV & $\begin{array}{lll}\mathrm{NC} & 003466.1 \\
\end{array}$ & 1997 & Chile & Aysen & Human case \\
\hline 1997.AR.AF482715_ORV & AF482715.1 & 1997 & Argentina & Oran & $\begin{array}{l}\text { Oligoryzomys } \\
\text { longicaudatus }\end{array}$ \\
\hline 1997.AR.AF482711_ANV & $\underline{\mathrm{AF} 482711.1}$ & 1997 & Argentina & Pergamino & Human case \\
\hline 1997.AR.AF482714_LEC & AF482714.1 & 1997 & Argentina & Lechiguanas & Oligoryzom ys flavescens \\
\hline 1995.PA.DQ345763_NEV & DQ345763.1 & 1995 & Paraguay & Neembucu & Oligoryzomys chacoensis \\
\hline 1997.AR.AF482713_BEV & $\underline{\mathrm{AF} 482713.1}$ & 1997 & Argentina & Bermejo & Oligoryzomys chacoensis \\
\hline 2005.CH.GQ279389_SEV & GQ279389.1 & 2005 & China & Beijing & Human case \\
\hline 2005.CH.GQ279380_SEV & GQ279380.1 & 2005 & China & Beijing & Human case \\
\hline 2005.CH.GQ279390_SEV & GQ279390.1 & 2005 & China & Beijing & Human case \\
\hline 2005.CH.GQ279388_SEV & GQ279388.1 & 2005 & China & Beijing & Rattus norvegicus \\
\hline 2004.CH.GQ279381_SEV & GQ279381.1 & 2004 & China & Beijing & Human case \\
\hline 2006.CH.GQ279379_SEV & $\underline{\text { GQ279379.1 }}$ & 2006 & China & Beijing & Human case \\
\hline 2004.CH.DQ217791_HTV & DQ217791.1 & 2004 & China & Shandong province & Human case \\
\hline 2006.CH.GQ279385_SEV & GQ279385.1 & 2006 & China & Shandong Province & Rattus norvegicus \\
\hline 2007.CH.FJ803211_SEV & FJ803211.1 & 2007 & China & $\begin{array}{l}\text { Coastal Region of } \\
\text { Zhejiang Province }\end{array}$ & gicus \\
\hline
\end{tabular}




\begin{tabular}{|c|c|c|c|c|c|}
\hline 2007.CH.FJ803206_SEV & FJ803206.1 & 2007 & China & $\begin{array}{l}\text { Coastal Region of } \\
\text { Zhejiang Province }\end{array}$ & Rattus norvegicus \\
\hline 2007.CH.FJ803210_SEV & $\underline{\text { FJ803210.1 }}$ & 2007 & China & $\begin{array}{l}\text { Coastal Region of } \\
\text { Zhejiang Province }\end{array}$ & Rattus norvegicus \\
\hline 2008.CH.GU361893_SEV & GU361893.1 & 2008 & China & & Rattus norvegicus \\
\hline 2006.CH.GQ279394_SEV & GQ279394.1 & 2006 & China & Beijing & Human case \\
\hline 2009.SC.HQ61 1980_SEV & $\underline{\text { HQ611980 }}$ & 2009 & $\begin{array}{l}\text { South } \\
\text { Korea } \\
\end{array}$ & Yalu River, North Korea & Rattus norvegicus \\
\hline 2003.CH.GQ279393_SEV & GQ279393.1 & 2003 & China & Beijing & Rattus norvegicus \\
\hline 2007.CH.AY750171_SEV & $\underline{\mathrm{AY} 750171.1}$ & 2007 & China & $\begin{array}{l}\text { Coastal Region of } \\
\text { Zhejiang Province }\end{array}$ & Rattus norvegicus \\
\hline 2004.CH.AY766368_SEV & AY766368.1 & 2004 & China & & Not determined \\
\hline 2007.CH.FJ803208_SEV & FJ803208.1 & 2007 & China & $\begin{array}{l}\text { Coastal Region of } \\
\text { Zhejiang Province }\end{array}$ & Rattus flavipectus \\
\hline 2007.CH.FJ803202_SEV & FJ803202.1 & 2007 & China & $\begin{array}{l}\text { Coastal Region of } \\
\text { Zhejiang Province }\end{array}$ & Rattus flavipectus \\
\hline 2007.CH.FJ803217_SEV & $\underline{\text { FJ803217.1 }}$ & 2007 & China & $\begin{array}{l}\text { Coastal Region of } \\
\text { Zhejiang Province }\end{array}$ & Rattus rattus \\
\hline 2007.CH.FJ803215_SEV & FJ803215.1 & 2007 & China & $\begin{array}{l}\text { Coastal Region of } \\
\text { Zhejiang Province }\end{array}$ & Rattus norvegicus \\
\hline 2007.CH.FJ803214_SEV & FJ803214.1 & 2007 & China & $\begin{array}{l}\text { Coastal Region of } \\
\text { Zhejiang Province }\end{array}$ & Rattus rattus \\
\hline 2007.CH.FJ803216_SEV & $\underline{\text { FJ803216.1 }}$ & 2007 & China & $\begin{array}{l}\text { Coastal Region of } \\
\text { Zhejiang Province }\end{array}$ & Rattus norvegicus \\
\hline 2007.CH.FJ803213_SEV & FJ803213.1 & 2007 & China & $\begin{array}{l}\text { Coastal Region of } \\
\text { Zhejiang Province }\end{array}$ & Rattus flavipectus \\
\hline 2004.CH.GQ279384_SEV & GQ279384.1 & 2004 & China & Beijing & Human case \\
\hline 2003.CH.GQ279392_SEV & GQ279392.1 & 2003 & China & Beijing & Rattus norvegicus \\
\hline 2003.CH.GQ279391_SEV & GQ279391.1 & 2003 & China & Beijing & Human case \\
\hline 2006.CH.GQ279387_SEV & GQ279387.1 & 2006 & China & Beijing & Rattus norvegicus \\
\hline 2004.CH.GQ279382_SEV & GQ279382.1 & 2004 & China & Beijing & Rattus norvegicus \\
\hline 2005.CH.GQ279386_SEV & GQ279386.1 & 2005 & China & Beijing & Rattus norvegicus \\
\hline 2006.CH.GQ279383_SEV & GQ279383.1 & 2006 & China & Beijing & Rattus norvegicus \\
\hline 2007.CH.FJ803205_SEV & FJ803205.1 & 2007 & China & $\begin{array}{l}\text { Coastal Region of } \\
\text { Zhejiang Province }\end{array}$ & Rattus norvegicus \\
\hline 2007.CH.FJ803207_SEV & FJ803207.1 & 2007 & China & $\begin{array}{l}\text { Coastal Region of } \\
\text { Zhejiang Province }\end{array}$ & Rattus norvegicus \\
\hline 1996.CH.GQ279395_SEV & GQ279395.1 & 1996 & China & Hebei Province & Human case \\
\hline 2005.CH.EF192308_SEV & EF192308.1 & 2005 & China & & Rattus norvegicus \\
\hline 2008.CH.JN377553_SEV & $\underline{\mathrm{JN} 377553}$ & 2008 & China & North China & Microtus fortis \\
\hline 2003.SC.AY273791_SEV & $\underline{\text { AY273791.1 }}$ & 2003 & $\begin{array}{l}\text { South } \\
\text { Korea }\end{array}$ & & Rattus norvegicus \\
\hline 2006.CH.EF536376_SEV & EF536376.1 & 2006 & China & & Mus norvegicus albus \\
\hline 2006.SI.GQ274945_SEV & GQ274945.1 & 2006 & Singapore & & Rattus norvegicus \\
\hline 2006.SI.GQ274944_SEV & $\underline{\text { GQ274944.1 }}$ & 2006 & Singapore & & Rattus norvegicus \\
\hline 2000.CH.AF288643_SEV & $\underline{\mathrm{AF} 288643.1}$ & 2000 & China & Shanxi Province & Human case \\
\hline 2003.CH.AF488707_SEV & $\underline{\mathrm{AF} 488707.1}$ & 2003 & China & & Human case \\
\hline 2007.CH.FJ803212_SEV & FJ803212.1 & 2007 & China & $\begin{array}{l}\text { Coastal Region of } \\
\text { Zhejiang Province }\end{array}$ & Rattus norvegicus \\
\hline 2007.CH.FJ803201_SEV & $\underline{\text { FJ803201.1 }}$ & 2007 & China & $\begin{array}{l}\text { Coastal Region of } \\
\text { Zhejiang Province }\end{array}$ & Rattus norvegicus \\
\hline 2006.SI.GQ274940_JRV & GQ274940.1 & 2006 & Singapore & & Rattus tanezumi \\
\hline 2006.SI.GQ274941_JRV & GQ274941.1 & 2006 & Singapore & Jurong city & Rattus tanezumi \\
\hline 1998.TH.AB186420_TAV & $\underline{\mathrm{AB} 186420.1}$ & 1998 & Thailand & & Bandicota indica \\
\hline 2004.TH.AM397664_TAV & $\underline{\text { AM397664.1 }}$ & 2004 & Thailand & Nakhon Ratchasima & Human case \\
\hline 2005.GE.GQ205403_DOV & GQ205403.1 & 2005 & Germany & $\begin{array}{c}\text { WG, Lüneburg district, } \\
\text { Lower Saxony }\end{array}$ & Apodemus agrarius \\
\hline 2005.GE.GQ205402_DOV & GQ205402.1 & 2007 & Germany & $\begin{array}{c}\text { WG, Lüneburg district, } \\
\text { Lower Saxony }\end{array}$ & Apodemus flavicollis \\
\hline 2005.GE.GQ205401_DOV & $\underline{\text { GQ205401.1 }}$ & 2007 & Germany & $\begin{array}{c}\text { WG, Lüneburg district, } \\
\text { Lower Saxony }\end{array}$ & Apodemus agrarius \\
\hline 2008.GE.GQ205407_DOV & $\underline{\text { GQ205407.1 }}$ & 2008 & Germany & $\begin{array}{l}\text { WG, Lüneburg district, } \\
\text { Lower Saxony }\end{array}$ & Apodemus agrarius \\
\hline 2008.GE.GQ205408_DOV & GQ205408.1 & 2008 & Germany & Western Pomerania & Apodemus flavicollis \\
\hline 2008.GE.JQ026204_DOV & $\underline{\mathrm{JQ} 026204}$ & 2008 & Germany & Greifswald & Apodemus flavicollis \\
\hline 2005.GE.GQ205404_DOV & $\underline{\text { GQ205404.1 }}$ & 2005 & Germany & WG, Lüneburg district, & Apodemus agrarius \\
\hline
\end{tabular}


Lower Saxony

\begin{tabular}{|c|c|c|c|c|c|}
\hline 2005.GE.GQ205406_DOV & GQ205406.1 & 2005 & Germany & $\begin{array}{l}\text { WG, Lüneburg district, } \\
\text { Lower Saxony }\end{array}$ & Apodemus flavicollis \\
\hline 2005.GE.GQ205405_DOV & GQ205405.1 & 2005 & Germany & $\begin{array}{l}\text { WG, Lüneburg district, } \\
\text { Lower Saxony }\end{array}$ & Apodemus agrarius \\
\hline 2000.DE.AJ616854_SAV & AJ616854.1 & 2000 & Denmark & & Apodemus agrarius \\
\hline 2002.RU.EU188452_DOV & EU188452.1 & 2002 & Russia & Lipetsk & Apodemus agrarius \\
\hline 2001.SL.AY533120_DOV & AY533120.2 & 2001 & Slovakia & Eastern & Apodemus agrarius \\
\hline 2001.SL.AY533118_DOV & $\underline{\text { AY533118.2 }}$ & 2001 & Slovakia & Eastern & Apodemus agrarius \\
\hline 2001.SK.AY961615_DOV & AY961615.1 & 2001 & Slovakia & Eastern & Apodemus agrarius \\
\hline 2001.SL.AY961618_DOV & AY961618.1 & 2001 & Slovakia & Eastern & Apodemus agrarius \\
\hline 2001.RU.EU18844_DOV & EU188449.1 & 2001 & Russia & Sochi & Apodemus ponticus \\
\hline 1998.SL.AY168576_DOV & AY168576.1 & 1998 & Slovakia & $\begin{array}{l}\text { Kosice } \\
\text { region }\end{array}$ & Apodemus flavicollis \\
\hline 1999.GE.AJ410619_DOV & AJ410619.1 & 1999 & Greece & Ano-Poroia, northeastern & Apodemus flavicollis \\
\hline 1999.GE.NC_005233_DOV & NC $\quad 005233.1$ & 1999 & Greece & Ano-Poroia, northeastern & Apodemus flavicollis \\
\hline 1999.GE.AJ410615_DOV & $\underline{\mathrm{AJ} 410615.1}$ & 1999 & Greece & Ano-Poroia, northeastern & Apodemus flavicollis \\
\hline 2004.GU.JQ082303_SSV & $\underline{\mathrm{JQ} 082303.1}$ & 2004 & Guine & Sangassou village & Hylomyscus simus \\
\hline 2004.GU.JQ082300_SSV & $\underline{\mathrm{JQ} 082300.1}$ & 2004 & Guine & Sangassou village & Hylomyscus simus \\
\hline 2005.CH.GU329991_HTV & GU329991 & 2005 & China & $\begin{array}{l}\text { Zhongdian County, } \\
\text { Yunnan province }\end{array}$ & Niviventer confucianus \\
\hline 1999.CH.AB027523_HTV & AB027523.1 & 1999 & China & Helongjian Province & Rattus rattus \\
\hline 2007.CH.EF121324_AMV & EF121324.1 & 2007 & China & & Apodemus peninsulae \\
\hline 2007.CH.JQ061291_AMV & JQ061291.1 & 2007 & China & Helongiian Province & Apodemus penisulae \\
\hline 1997.SC.AY675350_SOV & AY675350.1 & 1997 & $\begin{array}{l}\text { South } \\
\text { Korea }\end{array}$ & $\begin{array}{l}\text { Mt. Gyebang in } \\
\text { Hongcheon-gun }\end{array}$ & Apodemus \\
\hline 1997.SC.AY675349_SOV & AY675349.1 & 1997 & $\begin{array}{l}\text { South } \\
\text { Korea }\end{array}$ & $\begin{array}{l}\text { Mt. Gyebang in } \\
\text { Hongcheon-gun }\end{array}$ & Apodemus peninsulae \\
\hline 1999.RU.AB071184_AMV & $\underline{\mathrm{AB} 071184.1}$ & 1999 & Russia & Far East & Apodemus peninsulae \\
\hline 1999.RU.AB071183_AMV & $\underline{\mathrm{AB} 071183.1}$ & 1999 & Russia & Far East & Apodemus peninsulae \\
\hline 1997.SC.AY675352_SOV & AY675352.1 & 1997 & $\begin{array}{l}\text { South } \\
\text { Korea }\end{array}$ & $\begin{array}{l}\text { Mt. Gyebang in } \\
\text { Hongcheon-gun }\end{array}$ & Apodemusp \\
\hline 1997.CS.AY675351_SOV & AY675351.1 & 1997 & $\begin{array}{l}\text { South } \\
\text { Korea }\end{array}$ & $\begin{array}{l}\text { Mt. Gyebang in } \\
\text { Hongcheon-gun }\end{array}$ & Apodemus peninsulae \\
\hline 2006.CH.DQ658415_HTV & DQ658415.1 & 2006 & China & Jiangxi province & Human case \\
\hline 2007.CH.EF990915_HTV & EF990915.1 & 1986 & China & Guizhou Province & Apodemus agrarius \\
\hline 2007.CH.EF990914_HTV & EF990914.1 & 1986 & China & Guizhou Province & Apodemus agrarius \\
\hline 2007.CH.EF990913_HTV & EF990913.1 & 1986 & China & Guizhou Province & Apodemus agrarius \\
\hline 2007.CH.EF990912_HTV & EF990912.1 & 1986 & China & Guizhou Province & Apodemus agrarius \\
\hline 2000.CH.AF252259_HTV & $\underline{\mathrm{AF} 252259.1}$ & 2000 & China & Heilongiiang Province & Not determined \\
\hline 2002.RU.AB620031_HTV & $\underline{\mathrm{AB} 620031.1}$ & 2002 & Russia & Khabarovsk & Apodemus agrarius \\
\hline 2009.CH.HQ61 1981_HTV & $\underline{\mathrm{HQ6611981}}$ & 2009 & China & Yalu River, South China & Apodemus Agrarius \\
\hline 2003.CH.EF208929_HTV & EF208929.1 & 2003 & China & Peninsulae in Jilin & Apodemus peninsulae \\
\hline 2000.CH.AF288294_SEV & $\underline{\mathrm{AF} 288294.1}$ & 2000 & China & & Human case \\
\hline 2007.CH.FJ753398_HTV & FJ753398.1 & 2007 & China & & Apodemus agrarius \\
\hline 2007.CH.FJ753396_HTV & $\underline{\text { FJ753396.1 }}$ & 2007 & China & & Apodemus agrarius \\
\hline 2004.CH.EF990906_HTV & EF990906.1 & 2004 & China & Guizhou & Rattus norvegicus \\
\hline 2004.CH.EF990905_HTV & EF990905.1 & 2004 & China & Guizhou & Rattus norvegicus \\
\hline 2004.CH.EF990903_HTV & EF990903.1 & 2004 & China & Guizhou & Rattus norvegicus \\
\hline 2004.CH.EF990902_HTV & EF990902.1 & 2004 & China & Guizhou & Rattus norvegicus \\
\hline 2004.CH.EF990904_HTV & EF990904.1 & 2004 & China & Guizhou & Rattus norvegicus \\
\hline 2003.CH.GU140098_HTV & GU140098.1 & 2003 & China & $\begin{array}{c}\text { Kunming, Yunnan } \\
\text { province }\end{array}$ & Rattus norvegicus \\
\hline 1993.CH.AB027101_HTV & $\underline{\mathrm{AB} 027101.1}$ & 1993 & China & Helongjian Province & Rattus rattus \\
\hline 1999.CH.AB027097_HTV & $\underline{\mathrm{AB} 027097.1}$ & 1999 & China & Helongjian Province & Rattus rattus \\
\hline 2005.CH.EF990911_HTV & EF990911.1 & 2005 & China & Guizhou Province & Apodemus agrarius \\
\hline 2005.CH.EF990909_HTV & EF990909.1 & 2005 & China & Guizhou Province & Human case \\
\hline 2006.CH.EF990908_HTV & EF990908.1 & 2006 & China & Guizhou Province & Human case \\
\hline 2004.CH.EU092219_HTV & EU092219.1 & 2004 & China & Guizhou & Apodemus agrarius \\
\hline 2005.CH.EU363808_HTV & EU363808.1 & 2005 & China & Guizhou & Rattus norvegicus \\
\hline 2004.CH.EU092221_HTV & EU092221.1 & 2004 & China & Guizhou & Rattus norvegicus \\
\hline 2005.CH.EF990910_HTV & EF990910.1 & 2005 & China & nou Province & Apodemus agrarius \\
\hline
\end{tabular}




\begin{tabular}{llllll} 
1986.CH.EU363813_HTV & EU363813.1 & 1986 & China & Guizhou & Human case \\
\hline EU363812_HTV_CH_04 & EU363812.1 & 2004 & China & Guizhou & Rattus nitidus \\
\hline EU363811_HTV_CH_04.2 & EU363811.1 & 2004 & China & Guizhou & Rattus norvegicus \\
\hline EU363809_HTV_CH_86.2 & $\underline{\text { EU363809.1 }}$ & 1986 & China & Guizhou & Human case \\
\hline EU092220_HTV_CH_04.4 & EU092220.1 & 2004 & China & Guizhou & Apodemus agrarius \\
\hline
\end{tabular}




\section{MANUSCRITO I: EM AVALIAÇÃO}

Development of a one-step SYBR Green I real-time RT-PCR assay for the detection and quantitation of Araraquara Hantavirus

Alex Martins Machado ${ }^{*}$, William Marciel de Souza ${ }^{1 *}$, Michelly de Pádua ${ }^{1}$, Aline Rafaela da Silva Rodrigues Machado ${ }^{1}$ and Luiz Tadeu Moraes Figueiredo ${ }^{1}$.

1. Virology Research Center, School of Medicine in Ribeirão Preto, University of São Paulo, Av. Bandeirantes n.3900, Monte Alegre, Ribeirão Preto, São Paulo, Brazil. * Contributed equally to this study.

\section{ABSTRACT}

The genus Hantavirus consists of members of Bunyaviridae and is an emerging cause of disease worldwide with high lethality in the Americas. In Brazil, the diagnostic test for hantaviruses is based on immunologic techniques associated with conventional RT-PCR. A novel one-step SYBR Green real-time RT-PCR was developed for the detection and quantitation of Araraquara virus RNA by amplifying cDNA template from Araraquara virus RNA and using in vitro transcription to establish a standard curve. The assay had a detection limit of 10 copies $/ \mathrm{mL}$ of Araraquara virus RNA. The specificity was evaluated by melting curve analysis, which showed that the Araraquara virus amplified product generated a melt peak at $80.83 \pm 0.89^{\circ} \mathrm{C}$ without generating primer-dimers or non-specific products. The assay was more sensitive than conventional RT-PCR and was able to detect two samples undetected by conventional RT-PCR. The one-step SYBR Green real-time quantitative RT-PCR is specific, sensible and reproducible, which makes it a powerful tool in both diagnostic applications and general research of Araraquara hantavirus.

Keywords: Hantavirus, Araraquara virus, Real-time quantitative RT-PCR and SYBR Green I. 


\section{Introduction}

Hantaviruses are members of the Bunyaviridae family. These viruses have a trisegmented, negative-stranded RNA genome. The RNA segments are named small, medium and large [1]. Hantaviruses are transmitted to humans by the inhalation of aerosols of excreta or direct contact with infected rodents, although there are reports documenting the spread of Andes virus from human to human [2]. Severe diseases caused by hantaviruses are a serious public health problem worldwide. In the Americas, hantavirus infections produce Pulmonary Syndrome (HPS), which is characterized by fever, respiratory failure, shock and a high case fatality ratio $[1,2]$.

The first HPS cases in Brazil were diagnosed in 1993. Since then, approximately 1500 HPS cases have been reported, with a 39\% case fatality ratio [3]. Five hantaviruses were found to cause HPS in Brazil: Juquitiba virus, having Oligoryzomys nigripes as a rodent reservoir; Araraquara virus, having Necromys lasiurus as a reservoir; Castelo dos Sonhos virus, having Oligoryzomys aff. Moojeni and Oligoryzomys utiaritensis as reservoirs; Laguna Negra-like virus, having Calomys aff. Callosus and Calomys laucha as reservoirs; and Anajatuba virus, having Oligoryzomys fornesi as a rodent reservoir [1,4,5].

Serological methods are commonly used for hantavirus diagnosis, including enzymelinked immunosorbent assays (ELISAs), immunofluorescence assays, immunoblotting, and western blotting [1,6]. Hantavirus isolation in Vero E6 cell cultures and detection of hantavirus antibodies by plaque reduction neutralization are also used. However, both methods are labor-intensive, time-consuming, and require biosafety level 3 conditions, although these are hardly used in diagnostics [1,6,7].

Nucleic acid-based methods, such as polymerase chain reaction preceded by reverse transcription (RT-PCR), are suitable for the detection of hantaviruses [8-10]. In Brazil, a conventional RT-PCR was able to detect hantavirus genomes in blood and tissue samples of 
both humans and rodents [9]. Nevertheless, molecular techniques can evolve into faster, more sensitive methods that allow for the detection and quantitation of hantavirus in clinical samples.

Recently, real-time RT-PCR has been used for the diagnosis of hantaviruses such as Puumala, Hantaan, Tula, Seoul, Dobrava and Sin Nombre $[8,12,13]$. Real-time RT-PCR has many advantages over conventional RT-PCR, including rapidity, higher sensitivity and quantitative measurement [14].

Quantitative real-time RT-PCR methods using TaqMan probes have been described for Puumala, Andes, New York, Sin Nombre and Dobrava viruses $[10,12,13,14,16]$. In Brazil, a SYBR-Green-based real-time RT-PCR was developed for the diagnosis of Juquitiba virus infection in rodents captured in the Atlantic rainforest [17]. The technique was highly sensitive and specific but did not allow for viral quantitation. Therefore, in this study, the development and validation of first a SYBR Green-based real-time RT-PCR assay in South America. This assay can be used for detection and quantification for hantavirus Araraquara and Rio Mamore in clinical samples and virus-infected cells, respectively.

\section{Materials and methods}

\subsection{Serum sample and viral RNA extraction}

The viral RNA of an HPS patient serum sample was extracted using the QIAamp viral RNA extraction kit (Qiagen, Hilden, Germany) according to the manufacturer's protocol. The RNA was recovered in $50 \mu \mathrm{l}$ of RNase-free water with 40 units of RNase-OUT recombinant inhibitor (Invitrogen, Carlsbad, USA) and stored at $-70^{\circ} \mathrm{C}$.

\subsection{Plasmid cloning}

Use primer that has the annealing site in position of nucleotide 477 to 454 (forward) and 213 to 236 (reverse), was an amplicon of $\sim 264$ nucleotides of the hantavirus S segment, 
by conventional RT-PCR from the RNA extract of an HPS patient serum sample and confirmed by agarose gel electrophoresis [9]. This amplicon previous was cloned into a pCRTOPO 2.1 vector that was used to transform Escherichia coli DH5- $\alpha$ One Shot (Invitrogen, Carlsbad, USA) according to the manufacturer's protocol. Plasmids containing the insert were extracted using the QIAprep Spin Miniprep Kit (Qiagen, Hilden, Germany). The insert in the plasmid was amplified by conventional RT-PCR and was successfully cloned, subsequently sequenced, showed 99\% sequence homology to the RNA S segment of ARAV (EF571895.1).

\subsection{In vitro transcription}

Plasmids containing the insert were digested with BamHI restriction enzyme (Fermentas, Vilnius, Lithuania), and a transcription reaction with T7 RNA polymerase (Invitrogen, Carlsbad, USA) was performed, both according to the manufacturer's protocol. The obtained product was treated with DNAse I (Invitrogen, Carlsbad, USA) for 2 hours to degrade all plasmid DNA. The obtained ARAV RNA was extracted using the QIAamp viral RNA extraction kit (Qiagen, Hilden, Germany) and was recovered in $40 \mu$ l of nuclease-free water containing 40 units of RNase inhibitor and stored at $-70^{\circ} \mathrm{C}$.

\subsection{Standardization of the one-step SYBR Green I real-time quantitative RT-PCR}

The one-step SYBR Green I real-time quantitative RT-PCR was performed using the StepOnePlus $^{\mathrm{TM}}$ Real-Time PCR System (Applied Biosystems, Foster City, USA) and the SuperScript III Platinum One-Step qRT-PCR Kit (Invitrogen, Carlsbad, USA) using $20 \mu \mathrm{l}$ total volume. All reactions were performed in duplicate in 96-well optical reaction plates or MicroAmp reaction tubes (Applied Biosystems, Foster City, USA). Temperatures and times for the reactions were optimized, and the fluorescent reporter signal was determined at the end of each cycle using the internal reference dye (ROX) signal to avoid nonspecific fluorescence fluctuations. $X \mathrm{Rn}$, the fluorescence signal from the SYBR Green I normalized to the fluorescence signal of the passive reference (ROX), was obtained for each reaction. The 
melting temperature of the reaction $\left(\mathrm{T}_{\mathrm{M}}\right)$ is the temperature at which $50 \%$ of the oligonucleotide and its perfect complement are in duplex. Therefore, it was used to determine the specificity of amplified products. The $\mathrm{T}_{\mathrm{M}}$ curve was obtained by performing a thermal cycle of $95^{\circ} \mathrm{C}$ for 15 seconds decreased to $60^{\circ} \mathrm{C}$ for 1 minute, and increased again to $95^{\circ} \mathrm{C}$ for 15 seconds every $0,3^{\circ} \mathrm{C}$ a new fluorescence measurement was performed to determine the dissociation curve.

Different parameters were evaluated in the one-step SYBR Green I real-time quantitative RT-PCR, as shown in Table 1. Based on the results obtained, an optimal reaction mixture contained $2 \mu \mathrm{l}$ of template (ARAV RNA or RNA sample); $0.5 \mu \mathrm{l}$ of $\mathrm{MgSO}_{2} ; 0.35 \mu \mathrm{l}$ of each primer $(10 \mathrm{mM}) ; 10 \mu \mathrm{l}$ of SYBR buffer $(2 \mathrm{x}) ; 0.5 \mu \mathrm{l}$ of SuperScript III Platinum and 7.7 $\mu \mathrm{l}$ of MilliQ water in a final $20 \mu \mathrm{l}$ volume. The temperature cycles found to be optimal for the reaction were $50^{\circ} \mathrm{C}$ for 20 minutes for the production of cDNA; $95^{\circ} \mathrm{C}$ for 5 minutes to activate the Taq polymerase and separate double-stranded DNAs; and 45 cycles at $95^{\circ} \mathrm{C}$ for 15 seconds for denaturation; $55^{\circ} \mathrm{C}$ for 25 seconds for primer annealing and $72^{\circ} \mathrm{C}$ for 35 seconds for extension.

The reaction data were obtained and analyzed using StepOne version 2.1 (Applied Biosystems, Foster City, USA). The fluorescence threshold limit for the StepOnePlus ${ }^{\mathrm{TM}}$ RealTime PCR System was set at 0.02 as recommended by the manufacturer. The cycle threshold $\left(\mathrm{C}_{\mathrm{T}}\right)$, which is the number of cycles required for the fluorescent signal to cross the threshold limit, is inversely proportional to the amount of RNA target in the sample and was used to construct the standard curve for the reaction. The size of all obtained amplicons was determined by electrophoresis in $1.5 \%$ agarose gel.

2.5. Quantitation of the ARAV RNA based on a standard curve

The concentration of ARAV RNA was measured by optical density (OD) at 260 $\mathrm{nm} / 280 \mathrm{~nm}$ in a Thermo Scientific NanoDrop ${ }^{\mathrm{TM}} 1000$ Spectrophotometer (NanoDrop 
Technologies, Wilmington, USA). The number of RNA copies was calculated by the formula: RNA copy number $($ copies $/ \mathrm{ml})=($ RNA concentration $(\mathrm{g} / \mathrm{ml}) /$ number of nucleotides of transcript $\times 340) \times 6.022 \times 10^{23} \cdot \mathrm{C}_{\mathrm{T}}$ values of 10 -fold dilutions of ARAV RNA were used to create the standard curve. For each new reaction, a standard curve was created based on newly quantified ARAV RNA. The standard curve method is used to determine the absolute target quantity in samples, and StepOne measures the amplification of target in samples and standard dilution series. Thus, we were able to obtain a set of standards containing a range of known quantities. Data from the standard dilution series were used to generate the standard curve. Using the standard curve, StepOne interpolates the absolute quantity of target in the samples. A standard curve was constructed with the logarithm of the initial copy number of the standards plotted along the $\mathrm{x}$-axis and their respective CT values plotted along the $\mathrm{y}$-axis. The equation for the linear regression line was $y=m x+b$ or $C T=m(\log$ quantity $)+b]$. Using linear regression, it is possible to derive the following equation to determine the quantity $(\mathrm{N})$ of an unknown sample: $\mathrm{N}=10^{(\mathrm{CT}-\mathrm{b}) / \mathrm{m}}$. The copy number for each assay can be determined by entering the $\mathrm{CT}$ values of the individual replicate assays for samples A and B into this equation,. All the calculations were performed using StepOne (Applied Biosystems, Foster City, USA).

2.6. Specificity, reproducibility and detection limit of the reaction

The specific products of hantaviruses amplified in the reaction were identified by their $\mathrm{T}_{\mathrm{M}}$ peaks compared with those of the ARAV RNA. The specificity of the one-step SYBR Green I quantitative RT-PCR was checked by testing other RNA viruses, including Coxsackie B5, Influenza A, Human Respiratory Syncytial virus A, Parainfluenza-2, Metapneumovirus, Oropouche and Rhinovirus-39.

The reproducibility of the one-step SYBR Green real-time quantitative RT-PCR was analyzed based on the $\mathrm{T}_{\mathrm{M}}$, slope and $\mathrm{R}_{2}$ values obtained from decimal dilutions $\left(10^{8}\right.$ to $10^{3}$ 
copies $/ \mu \mathrm{l}$ ) of the ARAV RNA assayed in duplicate. Likewise, the detection limit of the reaction was determined by testing between $3,7 \times 10^{11}$ copies/ $\mathrm{ml}$ to $3,7 \times 10^{-3}$ copies/ $\mathrm{ml}$ of ARAV RNA in triplicate.

2.7. Comparison of the one-step SYBR Green I real-time quantitative RT-PCR with conventional RT-PCR

The efficiency of amplification and detection of hantavirus genome by the one-step SYBR Green real-time quantitative RT-PCR was compared with conventional RT-PCR. We extracted the RNA from 20 HPS patients serum sample and 10 macerated of lung tissues from Necromys lasiurus rodents using the QIAamp viral RNA extraction kit (Qiagen, Hilden, Germany) and tested our method with both reactions. The serum samples were all IgG positive to hantavirus via ELISA using the recombinant Nucleoprotein ( $\mathrm{N}$ Protein) of Araraquara hantavirus as an antigen [18]. Eight of the human serum samples also had a hantavirus genome amplified by conventional RT-PCR [9] and 5/10 Necromys lasiurus lung tissue samples contained amplicons of hantavirus by conventional RT-PCR.

\section{Results}

3.1. The standard curve of the one-step SYBR Green I real-time quantitative RT-PCR

The concentration of ARAV RNA was $8.4 \mathrm{ng} / \mu \mathrm{l}$, and it contained $3.7 \times 10^{11}$ copies/ ml. Equivalent $\Delta \mathrm{Rn}$ amplification plot curves were obtained when testing RNA ARAV at different dilutions in duplicate with values of 0,055305 . Decimal dilutions of the ARAV RNA were tested, and their $\mathrm{C}_{\mathrm{T}}$ values were plotted as the standard curve of the reaction. The parameters obtained for the SYBR Green I one-step real-time quantitative RT-PCR were: slope -3.075 (the ideal value is -3.200 ), percentage efficiency (EFF) 111.4\%; correlation coefficient $\left(\mathrm{R}_{2}\right) 0.995$ (the ideal value is $\left.<1.0\right)$ and $\mathrm{Y}$-inter 35,312. The $\mathrm{C}_{\mathrm{T}}$ values obtained from ARAV RNA dilutions were reproducible. Therefore, only one $T_{M}$ peak between 
$80.83 \pm 0.89^{\circ} \mathrm{C}$ was observed for many of the tested ARAV RNA samples, as shown in the melting curves in Figure 1A and with the samples in Figure 1B.

3.2. Reproducibility, detection limit and specificity of the reaction

The reaction was reproducible based on triplicate analysis of RNA ARAV. Positive samples showed only a small variation in parameters: $\mathrm{T}_{\mathrm{M}}$ : $80.64 \pm 0.67^{\circ} \mathrm{C}$; slope: $3,047 \pm 0,068$; $\mathrm{R}_{2}: 0,977 \pm 0,021$ and $\mathrm{C}_{\mathrm{T}}$ with variations of $3-7 \%$ in each triplicate, as previously described by the manufacturers. The negative control was water or buffer instead of sample template (buffer EB). The positive control was transcribed viral RNA, equivalent to that used in the standard curve.

The detection limit of the test was 10 copies/ ml based on triplicate analysis of ARAV RNA decimal dilutions $\left(3.7 \times 10^{11}\right.$ copies $/ \mathrm{ml}$ to $3.7 \times 10^{-3}$ copies $\left./ \mathrm{ml}\right)$.

The one-step SYBR Green I real-time quantitative RT-PCR did not amplify the genomes of other viruses including Coxsackie B5, Influenza A, Human Respiratory Syncytial virus A, Parainfluenza-2, Metapneumovirus, Oropouche and Rhinovirus-39. In these reactions, $\mathrm{T}_{\mathrm{M}}$ peaks always showed values below that of ARAV RNA, indicating that these were non-specific products or primer-dimers.

3.3. Comparison of the one-step SYBR Green real-time RT-PCR with conventional RT-PCR

The results obtained by conventional RT-PCR were compared with those of the SYBR Green I one-step real-time quantitative RT-PCR, and the SYBR Green I one-step real-time quantitative RT-PCR was shown to be a more sensitive method. Two serum samples of HPS patients that were negative by conventional RT-PCR had a hantavirus genome detected and quantified by the SYBR Green I one-step real-time quantitative RT-PCR, as shown in Table 2. Five lung samples from wild rodents that were positive by conventional RT-PCR were also positive by the one-step SYBR Green I real-time quantitative RT-PCR. 


\section{Discussion}

PCR has been used extensively worldwide for the diagnosis of viral infections, including those caused by hantaviruses [14]. Real-time PCR has several advantages over conventional PCR. It is faster, more sensitive, reproducible, allows for quantitative measurement, has lower hands-on-time and lower risk of contamination [10,14].

Recently, some quantitative real-time RT-PCRs, using TaqMan, were developed for quantitation of hantavirus [10-14]. Here we report, for the first time, a quantitative real time SYBR Green-based technique for the detection and quantitation of Araraquara virus, an important cause of HPS in the Southeast and Central Plateau of Brazil [19].

The main reason for the choice of a detection method based on SYBR Green is that RNA viruses present a diagnostic challenge. After consecutive reps, RNA viruses can generate genomic alterations, making them difficult to detect. Thus, the use of TaqMan probes, which have to be very specific, may produce false negative diagnoses due to genomic alterations in the binding sites with the probe [20]. Further, SYBER Green may lead to false positive results, this possibility was minimized in our study.

The one-step SYBR Green I real-time quantitative RT-PCR was highly sensitive, being able to detect 10 copies/ $\mu$ l of ARAV RNA. The test was also reproducible, based on equivalent melting curves and amplicon sizes obtained from hantavirus-infected samples in multiple reactions (Pryor, Wittwer, 2006; Aitichou et al. 2005; Evander et al. 2007). Moreover, the SYBR Green I-based real-time quantitative RT-PCR is a lower-cost reaction compared with other real-time RT-PCRs, such as TaqMan and Light Cycle [8,21].

The amplicons obtained with the one-step SYBR Green I quantitative RT-PCR were undoubtedly part of the hantavirus genome because the primers used amplify part of the $\mathrm{N}$ protein gene of Araraquara Hantavirus. This amplification occurs in a conserved region of the $\mathrm{N}$ protein gene, in fact, a previous analysis showed that these primers were also able to 
amplify the genomes of other South American hantaviruses (Moreli et al. 2004). The specificity of the reaction was confirmed by a $\mathrm{T}_{\mathrm{M}}$ curve, which was able to discriminate between hantavirus amplicons of primer-dimers and non-specific amplifications [8,13,21]. In addition, no amplification of genomes from other RNA viruses was obtained using the reaction.

The standard curve of the SYBR Green I real-time quantitative RT-PCR was based on reactions using a vector containing 263 nucleotides of the S segment of the Araraquara virus. The vector had been previously treated with DNAse I, preventing the amplification of remnants of plasmid DNA and erroneous measurements. Furthermore, DNAse I treatment prevented fluorophore binding to any sequence of double-stranded DNA $[8,11,14,21]$. The hantavirus load of clinical samples was quantified by plotting their $\mathrm{C}_{\mathrm{T}}$ reaction values on a standard curve based on the $\mathrm{C}_{\mathrm{T}}$ values of $10^{8}$ to $10^{3}$ copies/ ml of ARAV RNA (Figure 1B) $[11,22]$.

The one-step SYBR Green I quantitative RT-PCR was more sensitive for hantavirus diagnosis than conventional RT-PCR. From the sera of 20 human HPS patients, a hantavirus genome was amplified in 10 by the one-step SYBR Green I quantitative RT-PCR, including 2 samples that were not amplified by conventional RT-PCR. These 2 samples had low viral loads $\left(1,03 \times 10^{2}\right.$ and $7,4 \times 10^{1}$ copies/ $\left.\mathrm{ml}\right)$ that were likely below the detection capacity of conventional RT-PCR (Table 2). Therefore, the one-step SYBR Green I quantitative RT-PCR was performed more rapidly than conventional RT-PCR, taking approximately 2 hours. The one-step SYBR Green I quantitative RT-PCR could be used as a routine test for the diagnosis of HPS. It could also be useful for studies of the pathogenesis of hantaviruses, and for the analysis of the effect of antiviral drugs $[11,13]$. These assays can also be extended to research on new viruses, and detection by the SYBR Green real-time RT-PCR method may facilitate the surveillance of hantaviruses in Brazil and South America. 
In summary, the one-step SYBR Green real-time quantitative RT-PCR was able to detect and quantify the RNA of Araraquara and Rio Mamore hantavirus in serum, tissues and cell culture. The reaction showed high reproducibility and specificity and was more sensitive than conventional RT-PCR. Thus, this method is suitable for the rapid detection of the viral RNA of hantaviruses and the quantitation of viral copies in biological samples.

Acknowledgements

We are grateful to Eurico Arruda Neto, MD., PhD, Miriã Ferreira Criado, PhD, and José Luiz Proença-Modena, $\mathrm{PhD}$, for kindly donating the samples of Coxsackie B5, Influenza A, Human Respiratory Syncytial Virus A, Parainfluenza-2, Metapneumovirus, Oropouche and Rhinovirus-39. This study was supported by FAPESP - Fundação de Amparo a Pesquisa do Estado de São Paulo (Grant Number: 2008/50617-6; 2009/17518-9; 2011/05067-0; 2011/16866-1), Brazil.

Conflict of interest

We declare that we have no conflicts of interest with respect to this study.

References

1. Jonsson CB, Figueiredo LT, Vapalahti O (2010) A global perspective on Hantavirus ecology, epidemiology, and disease. Clin Microbiol Rev 23: 412-441

2. Hjelle B, Torres-Pérez F (2010) Hantaviruses in the Americas and Their Role as Emerging Pathogens. Virus 2:2559-2586

3. Brazilian Ministry Health. [cited 9 of February of 2013]. Available from: www.saude.gov.br

4. Travassos da Rosa ES, Medeiros DB, Nunes MR, Smith DB, de Souza Pereira A, Elkhoury MR, Lavocat M, Marques AA, Via AV, D'Andrea P, Bonvicino CR, Lemos ER, Vasconcelos PF (2011) Pygmy rice rat as potential host of Castelo dos Sonhos Hantavirus. Emerg Infect Dis $17: 1527-1530$

5. Travassos da Rosa ES, Mills JM, Padula PJ, Elkhoury MR, Ksiazek TG, Mendes, WS, Santos ED, Araújo GC, Martinez VP, Rosa JF, Edelstein A, Vasconcelos PF (2005) Newly 
recognized Hantaviruses associated with Hantavirus pulmonary syndrome in northern Brazil: partial genetic characterization of viruses and serologic implication of likely reservoirs. Vect Borne Zoon Dis 5:11-19

6. Vaheri A, Vapalahti O, Plyusnin A (2008) How to diagnose hantavirus infections and detect them in rodents and insectivores. Rev Med Virol 18:277-288

7. Machado AM, Figueiredo GG, Sabino GSJ, Figueiredo LTM (2009) Laboratory diagnosis of human Hantavirus infection: novel insights and future potential. Future Virology 4:383389.

8. Aitichou M, Saleh SS, Mcelroy AK, Schmaljohn C, Ibrahim MS (2005) Identification of Dobrava, Hantaan, Seoul, and Puumala viruses by one-step real-time RT-PCR. J Virol Methods 124: 21-26

9. Moreli LM, Sousa RLM, Figueiredo LTM (2004) Detection of brazilian Hantavirusby reverse transcription polymerase chain reaction amplification of $\mathrm{N}$ gene in patients with Hantavirus cardiopulmonary syndrome, Mem Inst Oswaldo Cruz 99: 633-638

10. Näslund J, Kerner A, Drobni P, Bucht G, Evander M, Ahlm C (2011). Detection of Puumala and Rift Valley Fever virus by quantitative RT-PCR and virus viability tests in samples of blood dried and stored on filter paper. J Virol Methods 178:186-190

11. Jakab F, Sebok J, Ferenczi E, Horváth G, Szucs G (2007) First detection of Dobrava Hantavirus from a patient with severe haemorrhagic fever with renal syndrome by SYBR Green-based real time RT-PCR. Scand J Infect Dis 39: 902-90.

12. Kramski M, Meisel H, Klempa B, Kruger DH, Pauli G, Nitsche A (2007) Detection and Typing of Human Pathogenic Hantaviruses by Real-Time Reverse Transcription-PCR and Pyrosequencing. Mol Diag Gen 11: 1899-1905

13. Evander M, Eriksson I, Pettersson L, Juto P, Ahlm C, Olsson GE, Bucht G, Allard A (2007) Puumala Hantavirus Viremia Diagnosed by Real-Time Reverse Transcriptase PCR Using Samples from Patients with Hemorrhagic Fever and Renal Syndrome. J Clin Microb 45:2491-2497

14. Mackay IM (2004) Real-time PCR in the microbiology laboratory. Clin Microbiol Infect 10: $190-212$

15. Saksida A, Duh D, Korva M, Avsic-Zupanc, T (2008) Dobrava virus RNA load in patients who have Hemorrhagic Fever with Renal Syndrome. J Infect Dis 197: 681-685

16. Trombley AR, Wachter, L., Garrison, J., Buckley-Beason, V.A., Jahrling, J., Hensley, L.E., Schoepp, R.J., Norwood , D.A., Goba, A. , Fair, J.N. , Kulesh, D.A. 2010. Comprehensive panel of real-time TaqMan Polymerase Chain Reaction assays for detection and absolute quantitation of filoviruses, arenaviruses, and new world hantaviruses. Am J Trop Med. Hyg 82, 954-960

17. Araujo J, Pereira A, Nardi MS, Henriques DA, Lautenschalagerv DA, Dutra LM, Ometto TL, Hurtado RF, Maues F, Nava A, Morais FA, Aires CC, Favorito S, Durigon EL (2011) 
Detection of hantaviruses in Brazilian rodents by SYBR-Green-based real-time RT-PCR. Arch Virol 156:1269-1274

18. Figueiredo LTM, Moreli ML, Borges AA, Figueiredo GG, Badra SJ, Bisordi I, Suzuki A, Capria S, Padula P (2009). Evaluation of a solid-phase enzyme immunoassay based on Araraquara Hantavirus recombinat nucleoprotein. Am J Trop Med Hyg 81: 273-276

19. Figueiredo LTM, Moreli ML, Souza RLM, Borges AA, Figueiredo GG, Machado AM, Bisordi I, Nagasse-Sugahara TK, Suzuki A, Pereira LE, de-Souza RP, de-Souza LT, Braconi CT, Harsi CM, de-Andrade-Zanotto PM; Viral Diversity Genetic Network Consortium. (2009) Hantavirus Pulmonary Syndrome in Central Plateau, Southeastern and Southern Brazil. Emerg Infect Dis 4:561-567

20. Papin JF, Vahrson W, Dittmer DP (2004) SYBR Green-based real time quantitative PCR assay for detection of West Nile virus circumvents false-negative results due to strain variability. J Clin Microbiol 42: 1511-1518

21. Pryor RJ, Wittwer CT (2006) Real- time polymerase chain reaction and melting curve analysis. Methods Mol Biol 336: 19-32

22. Fronhoffs S, Totzke G, Stier S, Wernert N, Rothe M, Brüning T, Koch B, Sachinidis A, Vetter H, Ko Y (2002) A method for the rapid construction of cRNA standard curves in quantitative real-time reverse transcription polymerase chain reaction. Mol Cell Prob 16:99110 


\section{MANUSCRITO II: EM PREPARAÇÃO}

Title: Evolution and spreading of rodent-borne hantavirus

William Marciel de Souza ${ }^{1}$, Gonzalo Bello ${ }^{2}$, Alberto Anastacio Amarrila Ortiz ${ }^{3}$, Helda Liz Alfonso $^{3}$, Victor Hugo Aquino Quintana ${ }^{3}$ and Luiz Tadeu Moraes Figueiredo ${ }^{1}$

1. Department of Biochemistry and Immunology, Virology Research Center, School of Medicine of Ribeirao Preto of University of São Paulo, Ribeirao Preto, São Paulo, Brazil.

2. Laboratório de AIDS \& Imunologia Molecular, Instituto Oswaldo Cruz, FIOCRUZ, Rio de Janeiro, Brazil.

3. Departamento de Análises Clínicas, Toxicológicas e Bromatológicas, Faculdade de Ciências Farmacêuticas, Universidade de São Paulo, Ribeirão Preto, São Paulo, Brazil.

\section{Funding}

This study was supported by FAPESP (Grant Number: 2011/05067-0). The funders had no role in study design, data collection and analysis, decision to publish, or preparation of the manuscript.

\section{Competing Interests}

The authors have declared that no competing interests exist.

\section{Abstract}

Hantavirus (Family Bunyaviridae) are mostly associated to rodents and transmitted to man by inhalation of aerosolized infected excreta of these animals. The human infection by Hantavirus can lead to severe diseases such as hemmorragic fever with renal syndrome (HFRS) in Asia and Europe, and pulmonary syndrome (HPS) in the Americas. To determine the origin, spreading and evolutionary dynamics of rodent-borne hantavirus, were collected 190 virus sequences of nucleoprotein $(N)$ gene from 30 countries, 1985 to 2010, and comparatively analyzed using the BEAST program. It was estimated that the $\mathrm{N}$ gene of hantavirus evolved at a rate of $6.8 \times 10^{-4}\left(2.5 \times 10^{-4}-1 \times 10^{-3}\right)$ nucleotide substitutions per site 
per year and that rodent-borne hantaviruses originated around 2,000 years ago. Rodent-borne hantavirus had a large period of slow growth and about 500 years ago started a rapid spread worldwide that coincides with the human traveling between continent. Hantaviruses associated to Murinae and Arvicolinae subfamilies, probably, were originated in Asia 500700 years ago spreading toward Siberia, Europe, Africa and North America. Hantaviruses associated to Neotominae subfamily, probably, emerged 500-600 years ago in Central America and spread toward North America. Finally, hantaviruses associated to Sigmodontinae occurred in Brazil 400 years ago and were, probably, originated from Neotominae-associated virus from northern South America. These data offer subsidies to understand the time-scale and worldwide dissemination dynamics of rodent-borne hantaviruses.

Keywords: Hantavirus, Rodent-borne, Evolution and Phylogeographic.

\section{Introduction}

Viruses of the genus Hantavirus, family Bunyaviridae, are enveloped viruses containing three segmets of single-stranded and negative-sense RNA. These segments are designated based on their size as small (S), medium (M) and large (L). The $\mathrm{S}$ segment encodes both the nucleoprotein $(\mathrm{N})$ and a small nonstructural protein (NSs) in an overlapping (+1) open reading frame, the $\mathrm{M}$ segment encodes two envelope glycoproteins ( $\mathrm{Gn}$ and $\mathrm{Gc}$ ), and the $\mathrm{L}$ segment encodes the RNA-dependent RNA polymerase (RdRp) (Jonsson, Figueiredo, Vapalahti, 2010; Jääskeläinen et al., 2007; Vera-Otarola et al., 2012).

Unlike other members of the Bunyaviridae family, which are trasmited by arthropods, hantaviruses are transmitted to humans particularly by Muridae or Cricetidae rodents through inhalation of excreta or aggressive interactions (Jonsson, Figueiredo, Vapalahti, 2010; Hjelle and Torres-Pérez, 2010). Nevertheless, novel hantavirus continue to be described in a wide range of species, including shrews and bats (Arai et al., 2008; Weiss et al., 2012, Guo et al., 
2013). The rodent-borne hantaviruses produce emerging infectious diseases that have a substantial impact on public health: the hemorrhagic fever with renal syndrome (HFRS) in Eurasia, and the hantavirus pulmonary syndrome (HPS) in the Americas (Jonsson, Figueiredo, Vapalahti, 2010).

As the phylogenetic inference of the rodent-borne viruses appear to be largely congruent with that of their hosts, hantaviruses are often considered to have co-diverged with rodent hosts over time-scales of millions of years (Morzunov et al., 1998; Hughes and Friedman, 2000, Plyusnin and Morzunov 2001; Nemirov et al., 2004). However, recent studies estimated that the hantavirus genus exhibit a short-term substitution rate too fast $\left(10^{-2}\right.$ to $10^{-4}$ substitutions/site/year) and divergence times too recent $(<1,000$ years ago $)$ that are not compatible with a cospeciation with their hosts (Ramsden et al., 2008; Ramsden et al., 2009). Thus, it has been proposed that apparent similarities between phylogeny of hantaviruses and that of their mammalian hosts are the result of a more recent history of preferential host switching and local adaptation.

To better understand the origin and the dissemination process of rodent-borne hantaviruses, we have analyzed a comprehensive data set including 252 nucleoprotein $(N)$ gene sequences of hantaviruses detected in humans and rodents worldwide. Spatial and temporal information on sequences were obtained by Bayesian analysis and allowed to reconstruct a time-scale and migration routes of hantavirus infecting Murinae, Arvicolinae, Neotominae and Sigmodontinae subfamilies of rodents.

\section{Materials and Methods}

\section{Sequence dataset}

Complete $N$ gene sequences (1,319 bp in length) of rodent-borne hantavirus deposited until November 2012 were retrieved from GenBank (www.ncbi.nlm.nih.gov). Two unpublished 
sequences of Araraquara virus isolated in Brazil were also included in the study (Supplementary 1). Known recombinant sequences were not included in the study. The data set was analyzed using the DAMBE 5.2.6 program in order to identify identical sequences, which were excluded from the analysis (Xia and Xie 2001). In our initial data set, samples from China were overrepresented $(n=86,34 \%)$ when compared to those from other countries $(n \leq 21)$. To avoid potential biases in the phylogeographic reconstructions due to unequal number of samples of different locations, we created a subset of "non-redundant" representative Chinese sequences. Thus, highly similar (identity $\geq 97 \%$ ) sequences from China were clustered with the CD-HIT program ( $\mathrm{Li}$ and Godzik 2006) using an online web server (Huang et al. 2010) and only one sequence per cluster was selected. Finally, it was obtained a data set of $190 N$ gene sequences identified from 30 countries over the past 25 years (Table 1).

\section{Evolutionary and Phylogeographic Analyses}

Nucleotide sequences were aligned using the CLUSTAL W program (Thompson et al., 1994) and hand edited. Alignment is available from the authors upon request. Based on this aligment, the spatio-temporal and demographic dynamics of dissemination of rodentborne hantavirus was reconstructed using the Bayesian Markov Chain Monte Carlo (MCMC) approach using the BEAST 1.7.4 program (Drummond et al., 2012). For these analysis, were performed using the general time reversible $\mathrm{GTR}+\mathrm{I}+\mathrm{G}$ nucleotide substitution model, an uncorrelated Lognormal relaxed molecular clock model (Drummond et al., 2006) and a Bayesian skyline coalescent model (Drummond et al., 2005), as previously described (Ramsden et al, 2009). Time-scale was inferred using an informative substitution rate (1.0 x $10^{-4}-1.0 \times 10^{-3}$ substitutions/site/year) previously estimated for the $N$ gene of rodent-borne hantavirus (Ramsden et al., 2008; Ramsden et al., 2009). Migration events throughout the phylogenetic history were identified by applying a standard discrete Bayesian 
phylogeographic model (Lemey et al., 2009). MCMC chain was run for 1 x $10^{8}$ generations and adequate chain mixing was checked, after excluding an initial $10 \%$, by calculating the effective sample size (ESS) using TRACER v1.4 program (http://beast.bio.ed.ac.uk/Tracer). Maximum clade credibility (MCC) trees were summarized from the distribution of trees with $\begin{array}{lllll}\text { TreeAnnotator and } & \text { were } & \text { visualized } & \text { FigTree }\end{array}$ (http://tree.bio.ed.ac.uk/software/figtree).

\section{Results}

The Bayesian phylogenetic analysis of 190 hantavirus $N$ gene sequences confirmed the existence of two highly supported (Posterior Probability $[P P]=1$ ) monophyletic clades associated with the rodent host families Muridae (subfamily Murinae) and Cricetidae (subfamilies Arvicolinae, Neotominae and Sigmodontinae) (Figure 1A). Viruses included in the Cricetidae family were subdivided in two reciprocally monophyletic clades $(P P=1)$ related to Arvicolinae and Neotominae/Sigmodontinae subfamilies. The Sigmodontinae hantaviruses branched in a well supported $(P P=1)$ monophyletic subcluster that was nested within the paraphyletic group of Neotominae hantaviruses. The analysis also supported a strong subdivision of hantaviruses into genus or tribe of their rodent hosts (Figure 1B). Muridae-borne hantaviruses adapted to rodents of genus Apodemus and Rattus, the Arvicolinae-associated viruses were mostly found in natural hosts of the genus Myodes or Microtus. Neotominae-associated hantaviruses adapted to genus Peromyscus and Reithrodontomys (both belong to Reithrodontomyini tribe). The Sigmodontinae hantaviruses were found principally in Oryzomyini and Akodontini tribes.

The estimated rate of nucleotide substitutions per site per year for the $N$ gene of hantavirus was $6.8 \times 10^{-4}$. The 95\% HPD interval of such estimate $\left(2.5 \times 10^{-4}-1 \times 10^{-3}\right.$ subst./site/year) almost coincided with the informative prior interval $\left(1.0 \times 10^{-4}-1.0 \times 10^{-3}\right.$ subst./site/year), thus indicating a correlation between both data. According to this estimated 
rate, the most recent common ancestor $\left(\mathrm{T}_{\mathrm{MRCA}}\right)$ for all rodent-borne hantaviruses occurred 1,915 years before present (ybp) (95\% HPD: 5,541 - 922 ybp) (Figure 1A). Based on the Bayesian skyline plot, the effective number of hantavirus lineages underwent an initial period of slow growth between 2,000 and $500 \mathrm{ybp}$, followed by an intermediate period of fast growth, around $500 \mathrm{ybp}$, followed by a slowdown in the spreading rate at the last five decades (Figure 2). Of note, the expansion phase of hantavirus lineages roughly coincides with the estimated emergence of major hantaviruses subfamily clades: Murinae (573 ybp, 95\% HPD 1,644-339 ybp), Arvicolinae (628 ybp, 95\% HPD $1,782-384 \quad$ ybp $)$ and Neotominae/Sigmodontinae (549 ybp, 95\% HPD 1,555-341 ybp) (Figure 1A).

This phylogeographic study, based on posterior root state probability $(P R S P)$ and the most relevant nodes of the Bayesian tree, allowed to infer on the spreading of hantaviruses around the world (Figures 3 and 4).

\section{Discussion}

The evolutionary history of family Bunyaviridae is a long process that is related to that of their natural carriers. A codivergence between hantaviruses and their hosts has been accepted for decades because phylogenetic trees of rodent-borne hantaviruses show main clades that correspond to subfamilies of their rodent natural reservoirs (Hughes and Friedman 2000; Plyusnin and Morzunov 2001; Nemirov et al., 2004). However, recent studies showed that hantaviruses exhibit fast short-term evolutionary rates and relatively recent $\mathrm{T}_{\mathrm{MRCA}}$ estimates that were not compatible with a codivergence of hantaviruses with their rodents hosts (Ramsden et al., 2008, Ramsden et al., 2009). Using the evolutionay rate previously calculated for the $\mathrm{S}$ segment of hantavirus genome $\left(1 \times 10^{-4}-1 \times 10^{-3}\right.$ subst./site/year) (Ramsden et al. 2008, 2009), it is possible to estimate an approximate median $\mathrm{T}_{\mathrm{MRCA}}$ between 400 and $600 \mathrm{ypb}$. In the present study, the $\mathrm{T}_{\mathrm{MRCA}}$ estimations for all rodent-borne hantaviruses 
are quite older than those reported by Ramdsen et al ( 850 ybp) and for major subfamily clades ( 200-250 ybp), but still not consistent with the hypothesis of viral-host codivergence.

Our demographic reconstruction showed that the hantavirus population remained relatively constant over a long period of time $(2,000$ to $500 \mathrm{ybp})$ but, around $500 \mathrm{ybp}$, it started to grow fast, coinciding with origin and spreading of current major clades of hantavirus. This process is concomitant with the beginning of modern agriculture that increased food sources for animal species including rodents that have commensal and synanthropic behaviors. The process is also concomitant with the human navigation era between Old World and New World continents. Thus, probably, human activity influenced the spread of rodent reservoirs of hantavirus. Interestingly, the skyline plot graph (Figure 2) shows a reduction of hantavirus populations in the last 50 years, reflecting a possible recent decline of hantavirus-host populations and viral transmission.

Our phylogeographic study suggests that the Murinae-associated hantaviruses originated in China 550-600 ybp, being the ancestors of Hantaan virus, the prototype of Hantavirus genus, from striped field mouse (Apodemus agrarius) and a causative of HFRS (Lee et al. 1981). The geographical position of China and the presence of rodents of both Rattus and Apodemus genera, probably, played a key role in virus dissemination to other countries (Figure 4). Once well adapted to Chinese population of Rattus, the ancestral hantavirus probably moved from China to South Korea originating Seoul virus, the probable etiological agent of a HFRS outbreak that affected more than 3,000 United Nations troop during the Korean War (1950 to 1953) (Lee et al., 1978). Probably, these viruses also moved from China to Southeast Asia originating Thailand and Jurong viruses, both well adapted to rodents of Rattus genus (Hugot et al., 2006, Johansson et al., 2010). Murinae hantavirus, probably carried by Apodemus rodents, also arrived to Siberia and Europe originating Dobrava virus and their variations, that are cause of HFRS in those regions (Papa, 2012). 
Finally, Murinae hantavirus moved from Asia into Africa, probably crossing through the Middle East; although this route is largely speculative due to the paucity of hantaviruses described in those regions. Until now, only one specie of rodent-borne hantavirus was reported in Africa (Guinea Conakry) in Hylomyscus simus rodents (Klempa et al., 2012).

Hantaviruses related to the Arvicolinae rodent subfamily started probably in China or Siberia 600-650 ybp (Figure 4). Most of these Arvicolinae hantaviruses from Asia adapted to genus Myodes and gave rise to different species, such as Puumala, Khabarovsk and Ussuri viruses in Russia, and Shenyang and Yuanjiang viruses in China (Jonsson, Figueiredo, Vapalahti, 2010; Zou et al., 2008). The virus probably spread from Siberia to Japan, originating Hokkaido virus (Kariwa et al., 1999). It also spread from Russia to Scandinavia adapting to Myodes rodents (previously known as Clethrionomys). This lineage originated Puumala virus and their variations, responsible by the epidemic nephropathy (HFRS) in that region (Jonsson, Figueiredo, Vapalahti, 2010). Simultaneously, Arvicolinae hantavirus adapted to Microtus genus hosts and spread toward Asia (Kazakhstan), Europe and North America. In Asia and Europe, an ancestral Arvicolinae hantavirus originated Tula virus which is, probably, non-pathogenic to humans (Schlege et al., 2012). The migration route of these viruses from Asia/Europe to North America is unknown. In North America Arvicolinae hantavirus originated Isla Vista and Prospect Hill virus (Jonsson, Figueiredo, Vapalahti, 2010).

Hantaviruses associated to Neotominae probably emerged in Central America or Mexico 500-600 ybp, and evolved to originate Carrizal virus and the Huitzilac virus in Mexico, and Rio Segundo virus in Costa Rica (Kariwa et al., 2012). The estimated arrival time of Neotominae hantavirus in the Americas coincides with the discovery of America and beginning of navigation between the Old and the New World, in the 16th Century. Hantaviruses from Central America and/or Mexico spread northward originating Sin Nombre 
virus that was responsible for the first outbreak of HPS, in 1993 (Nichol et al., 1993) (Figure 4). There was also a Neotominae hantavirus that migrated southward and originated Caño Delgadito virus in Venezuela, related to Sigmodon alstoni. The Neotominae hantaviruses are well adapted to American rodents of genus Peromyscus and Reithrodontomys.

In South America, ancestral Neotominae hantavirus probably, spread among Sigmodontinae species originating a clade. Notably, Caño Delgadito virus branched between Neotominae hantavirus from Central America and those from South America (Figure 1), thus, suggesting a evolutionary link between these two viral clades. Most South American Sigmodontinae hantaviruses are adapted to rodents of Oryzomyini and Akodontini tribes (Parada et al., 2013). Sigmodontinae hantavirus were also reported in Central America, Choclo virus was described in Panama associated to Oligoryzomys fulvescens (Vincent et al., 2000).

The origin of Sigmodontinae clade of hantavirus can be found in Brazil $400 \mathrm{ybp}$ (Figure 4). The ancestral Sigmodontinae virus originated Juquitiba, the first hantavirus causing HPS reported in Brazil, and Araraquara virus that produces HPS with the highest case fatality ratio in the world (Figueiredo et al., 2009). The Sigmodontinae hantavirus clade was exported to Bolivia and Peru, originating Rio Mamore virus and Paraguay, originating Laguna Negra virus (Jonsson, Figueiredo, Vapalahti, 2010). The Sigmodontinae hantavirus clade was also exported to Argentina originating Andes virus, the first hantavirus identified in South America, in 1993 (Padula et al., 1998; Hjelle and Torres-Pérez, 2010). The Sigmodontinae hantavirus clade disseminated from Argentina back to Brazil as well as to Bolivia and Chile reaching Panama.

The progress of Bayesian methods in the last decade using complex evolutionary models allowed to create robust methods for phylogenetic reconstruction. Using these powerful tools it is possible to understand the evolutionary process of many species including 
viruses (Drummond et al. 2005). For the present study, it was analysed the most extensive data set of rodent-borne hantaviruses up to date. However, it is important to consider for our analyzis that evolutionary and phylogeographic reconstructions are sensitive to both: unequal sampling sizes from different locations and the absence or extinct basal viral lineages. In our data set, eventual bias could happen due to a limited number of available sequences of hantavirus. Therefore, a recent study showed that molecular clock analyses calibrated by modern sequences may produce quite accurate inferences over short-term, but errors could arise at larger time scales for fast evolving RNA viruses, due to stringent evolutionary constraints and saturation by nucleotide substitutions in the same site (Worobey et al., 2010). In conclusion, our study suggests that the rodent-borne hantavirus were originated around 2,000 years ago, and that the subfamily clades of them emerged around 500 years ago, thus, contradicting the hypothesis of codivergence between hantaviruses and their hosts. The combination of relative recent events of cross-species virus transmission and subsequent viral adaption to particular subfamily, genus and tribe of voles dominant within a given territory and/or ecological niche, may have shaped current genetic diversity and global distribution of hantaviruses. Our phylogeographic analysis suggests that Asia was the most probable epicenter of dissemination of both the Murinae and Arvicolinae subfamilies, meanwhile Central America and Brazil were traced as the most probable places of origin of Neotominae and Sigmodontinae subclades, respectively. These data presented here provide a comprehensive understanding of the dynamics of the hantavirus associated with rodents and their worldwide dissemination, which may be helpful to guide characterisation, identification of factors that promote transmission and distribution, and also classification of these viruses. 


\section{References}

Jonsson CB, Figueiredo LT, Vapalahti, O (2010) A global perspective on Hantavirus ecology, epidemiology, and disease. Clin Microbiol Rev 23: 412-441.

Jääskeläinen KM, Kaukinen P, Minskaya ES, Plyusnina A, Vapalahti O, et al. (2007) Tula and Puumala hantavirus NSs ORFs are functional and the products inhibit activation of the interferon-beta promoter. J Med Virol 79: 1527-1536.

Vera-Otarola J, Solis L, Soto-Rifo R, Ricci EP, Pino K, et al. (2012) The Andes hantavirus NSs protein is expressed from the viral small mRNA by a leaky scanning mechanism. $\mathrm{J}$ Virol 86: 2176-2187.

Hjelle B, Torres-Pérez F (2010) Hantaviruses in the Americas and Their Role as Emerging Pathogens. Virus 2: 2559-2586.

Arai S, Ohdachi SD, Asakawa M, Kang HJ, Mocz G, et al. (2008) Molecular phylogeny of a newfound hantavirus in the Japanese shrew mole (Urotrichus talpoides). Proc Nat Acad Sci USA 105: 16296-16301.

Weiss S, Witkowski PT, Auste B, Nowak K, Weber N, et al. (2012) Hantavirus in bat, Sierra Leone. Emerg Infect Dis 18: 159-161.

Guo WP, Lin XD, Wang W, Tian JH, Cong ML, et al. (2013) Phylogeny and Origins of Hantaviruses Harbored by Bats, Insectivores, and Rodents. PLoS Pathog 9: e1003159.

Morzunov SP, Rowe JE, Ksiazek TG, Peters CJ, St Jeor SC et al. (1998) Genetic analysis of the diversity and origin of hantaviruses in Peromyscus leucopus mice in North America. J Virol 72: 57-64.

Hughes AL, Friedman R (2000) Evolutionary diversification of protein coding genes of hantaviruses. Mol Biol Evol 17: 1558-1568.

Plyusnin A, Morzunov SP (2001) Virus evolution and genetic diversity of hantaviruses and their rodent hosts. Curr Top Microbiol Immunol 256: 47-75.

Nemirov K, Henttonen H, Vaheri A, Plyusnin A (2002) Phylogenetic evidence for host switching in the evolution of hantaviruses carried by Apodemus mice. Virus Res 90: 207-215.

Ramsden C, Melo FL, Figueiredo LTM, Holmes ED, Zanotto PMA et al. (2008) High Rates of Molecular Evolution in Hantaviruses. Mol Biol Evol 25: 1488-1492.

Ramsden C, Holmes EC, Charleston MA (2009) Hantavirus evolution in relation to its rodent and insectivore hosts: no evidence for codivergence. Mol Biol Evol 26: 143-153.

Li W, Godzik A (2006) CD-HIT: a fast program for clustering and comparing large sets of protein or nucleotide sequences. Bioinformatics. 22:1658-1659. 
Xia X, Xie Z: DAMBE: software package for data analysis in molecular biology and evolution. J Hered 2001, 92:371-373.

Huang Y, Niu B, Gao Y, Fu L, Li W (2010) CD-HIT Suite: a web server for clustering and comparing biological sequences. Bioinformatics. 26:680-682.

Thompson JD, Higgins DG, Gibson TJ (1994) CLUSTAL W: improving the sensitivity of progressive multiple sequence alignment through sequence weighting, position-specific gap penalties and weight matrix choice. Nucleic Acids Res 22: 4673-4680.

Drummond AJ, Suchard MA, Xie D, Rambaut A (2012) Bayesian phylogenetics with BEAUti and the BEAST 1.7. Mol Biol Evol 29: 1969-1973.

Drummond AJ, Ho SY, Phillips MJ, Rambaut A (2006) Relaxed phylogenetics and dating with confidence. PLoS Biol 4: e88.

Drummond AJ, Rambaut A, Shapiro B, Pybus OG (2005) Bayesian coalescent inference of past population dynamics from molecular sequences. Mol Biol Evol 22:1185-1192.

Lemey P, Rambaut A, Drummond AJ, Suchard MA (2009) Bayesian phylogeography finds its roots. PLoS Comput Biol 5: e1000520.

Lee HW, Lee PW, Baek LJ, Song CK, Seong IW (1981) Intraspecific transmission of Hantaan virus, etiologic agent of Korean hemorrhagic fever, in the rodent Apodemus agrarius. Am J Trop Med Hyg 30:1106-1112.

Lee HW, Lee, PW, Johnson KM (1978) Isolation of the etiologic agent of Korean hemorrhagic fever. J Infect Dis 137: 298-308.

Hugot JP, Plyusnina A, Herbreteau V, Nemirov K, Laakkonen J, et al. (2006) Genetic analysis of Thailand hantavirus in Bandicota indica trapped in Thailand. Virol J 3:72.

Johansson P, Yap G, Low HT, Siew CC, Kek R, Ng LC, Bucht G (2010) Molecular characterization of two hantavirus strains from different rattus species in Singapore. Virol J 22:7:15.

Papa A (2012) Dobrava-Belgrade virus: Phylogeny, epidemiology, disease. Antiviral Res 95:104-117.

Klempa B, Witkowski PT, Popugaeva E, Auste B, Koivogui L, et al (2012) Sangassou virus, the first hantavirus isolate from Africa, displays genetic and functional properties distinct from those of other murinae-associated hantaviruses. J Virol 86: 3819-3827.

Zou Y, Xiao QY, Dong X, Lv W, Zhang SP, et al. (2008) Genetic analysis of hantaviruses carried by reed voles Microtus fortis in China. Virus Res 137: 122-128.

Kariwa H, Yoshimatsu K, Sawabe J, Yokota E, Arikawa J, e al. (1999) Genetic diversities of hantaviruses among rodents in Hokkaido, Japan and Far East Russia. Virus Res 59: 219-228. 
Schlegel M, Kindler E, Essbauer SS, Wolf R, Thiel J, et al. (2012) Tula virus infections in the Eurasian water vole in Central Europe. Vect Borne Zoo Dis 12: 503-513.

Kariwa H, Yoshida H, Sánchez-Hernández C, Romero-Almaraz Mde L, Almazán-Catalán JA, et al. (2012) Genetic diversity of hantaviruses in Mexico: identification of three novel hantaviruses from Neotominae rodents. Virus Res 163:486-494.

Nichol ST, Spiropoulou CF, Morzunov S, Rollin PE, Ksiazek TG et al. (1993) Genetic identification of a hantavirus associated with an outbreak of acute respiratory illness. Science 262: 914-917.

Parada A, Pardiñas UF, Salazar-Bravo J, D'Elía G, Palma RE (2013). Dating an impressive Neotropical radiation: Molecular time estimates for the Sigmodontinae (Rodentia) provide insights into its historical biogeography. Mol Phylogenet Evol 66: 960-968.

Vincent MJ, Quiroz E, Gracia F, Sanchez AJ, Ksiazek TG, et al. (2000) Hantavirus pulmonary syndrome in Panama: identification of novel hantaviruses and their likely reservoirs. Virology 277: 14-9.

Figueiredo LTM, Moreli ML, de Souza LM, Borges AA, Figueiredo GG, et al. (2009) Hantavirus pulmonary syndrome, Central Plateau, Southeastern, and Southern Brazil. Emerg Infect Dis 15: 561-567.

Padula PJ, Edelstein A, Miguel SDL, López NM, Rossi CM, Rabinovich RD (1998) Hantavirus pulmonary syndrome outbreak in Argentina: Molecular evidence for person-toperson transmission of Andes virus. Virology 241:323-330.

Worobey M, Telfer P, Souquière S, Hunter M, Coleman CA, et al. (2010) Island Biogeography Reveals the Deep History of SIV. Science 329; 1487. 